\title{
Türkiye'de Hukuk Eğitimi, Mevzuat ve Uygulamada Toplumsal Cinsiyete Duyarlılık
}

\author{
Gender Sensitivity in Legal Education, Legislation and Practice in Turkey
}

\begin{abstract}
Özlem Yenerer Çakmut ${ }^{*}$ (D), Özge Yücel Dericiler** (D), Sendi Yakuppur*** (DD, Ișık Özer*** (D), Ferhat Ylldırım ${ }^{* * * *}$ (D)
\end{abstract}

\section{öz}

Eğitim, içerik ve yöntemine bağlı olarak toplumsal cinsiyete dayalı ayırımcılığı yeniden üreten süreçlerden biri olabileceği gibi, toplumsal cinsiyet eşitsizliğiyle mücadelenin temel araçlarından biri de olabilir. $\mathrm{Bu}$ nedenle, eğitimin her kademesinde ve eğitim yoluyla toplumsal cinsiyet eşitliğinin sağlanmasını sorunsallaştırmak önem taşır. Aynı nedenle ve hukukun ataerkil bir sistem olduğu kabulünden hareketle, hukuk eğitiminin ve eğitimde kullanılan materyallerin de toplumsal cinsiyet perspektifinden gözden geçirilmesi gerekir. Bu çalışma, bir Hukuk Fakültesinden bir grup akademisyenin bir araya gelerek kendi alanlarıyla ilgili mevzuatı ve uygulamaları toplumsal cinsiyet açısından incelemeleri ve tespit ettikleri sorunlar ile önerilerini bir araya getirmeleriyle ortaya çıkmıştır. Bu kapsamda, öncelikle toplumsal cinsiyet kavramı ve hukuk ile ilişkisine ilişkin çerçeve çizilmiş, daha sonra medeni hukuk, ceza hukuku, ticaret hukuku ve uluslararası insan hakları hukukunda toplumsal cinsiyete ilişkin, öğrencilerin dikkatlerine sunulması gerektiği düşünülen sorunlar değerlendirilmiştir.

Anahtar Kelimeler: Hukuk eğitimi, Toplumsal cinsiyet, Eşitlik, Ayırımcılık, Sürdürülebilir kalkınma

\section{ABSTRACT}

Education can be one of the processes that reproduce gender-based discrimination depending on its content and method but can also be one of the main tools to combat gender inequality. For this reason, it is important to problematize the achievement of gender equality at all levels of education and through education. For the same reason, and considering that law is a patriarchal system, legal education and the materials used in education should be reviewed from a gender perspective. This study has emerged by a group of academics from a Faculty of Law who came together to examine the legislation and practices related to their field in terms of gender. In this context, first of all, the framework regarding the concept of gender and its relationship with law was drawn, then the issues related to gender in civil law, criminal law, commercial law and international human rights law were evaluated.

Keywords: Legal education, Gender, Equality, Discrimination, Sustainable development

* Prof. Dr., Özyeğin Üniversitesi Hukuk Fakültesi Ceza ve Ceza Muhakemesi Hukuku ABD., ozlem.cakmut@ozyegin.edu.tr, ORCID ID: https://orcid.org/0000-0002-5247-5062.

** Dr. Öğr. Üyesi, Özyeğin Üniversitesi Hukuk Fakültesi Genel Kamu Hukuku ABD, ozge.yucel@ozyegin.edu.tr, ORCID ID: https://orcid.org/0000-0002-7368-8067.

*** Dr. Öğr. Üyesi, Özyeğin Üniversitesi Hukuk Fakültesi Medeni Hukuk ABD, sendi.yakuppur@ozyegin.edu.tr, ORCID ID: https://orcid.org/0000-0001-9234-1715.

**** Dr. Öğr. Üyesi, Özyeğin Üniversitesi Hukuk Fakültesi Ticaret Hukuku ABD, isik.ozer@ozyegin.edu.tr, ORCID ID: https:// orcid.org/0000-0001-6588-8934.

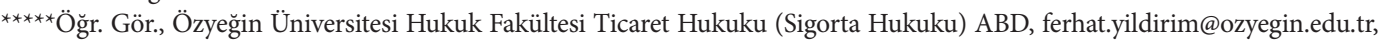
ORCID ID: 0000-0002-6745-8820.

Sorumlu Yazar/Correspondence Author: Özge Yücel Dericiler

E-posta/E-mail: ozge.yucel@ozyegin.edu.tr

Geliş Tarihi/Received: $\quad$ 15.09.2021 


\section{GíRiş}

Cinsiyet eşitsizliği ve toplumsal cinsiyete dayalı ayırımcılık, hem ülkemizin hem de dünyanın temel sorunlarından biridir. Eğitim ise içerik ve yöntemine bağlı olarak, toplumsal cinsiyete dayalı ayırımcılığı yeniden üreten süreçlerden biri olabileceği gibi, toplumsal cinsiyet eşitsizliğiyle mücadelenin temel araçlarından biri de olabilir. Bu nedenle, eğitimde ve eğitim yoluyla toplumsal cinsiyet eşitliğinin sağlanmasını sorunsallaştırmak önem taşır.

Birleşmiş Milletler (BM) düzeyinde bakıldığında toplumsal cinsiyet eşitliğinin sağlanması ve tüm kadınların ve kız çocuklarının güçlendirilmesi, belirlenmiş on yedi sürdürülebilir kalkınma hedefinden biri olarak karşımıza çıkar ${ }^{1}$. Toplumsal cinsiyet eşitliğinin sadece bir temel hak olmadığı, aynı zamanda barışçıl, müreffeh ve sürdürülebilir bir dünya için gereklilik olduğu kabul edilmektedir. BM, okula devam eden kız çocuk sayısının artması, erken yaşta evliliğe zorlanan kız çocuklarının sayısının azalması, yönetsel pozisyonlardaki kadınların sayısının artması gibi konularda gelişmeler olmakla birlikte hala pek çok mücadele alanının mevcut olduğuna, ayırımcı yasaların ve toplumsal normların hala yaygın olduğuna dikkat çeker ${ }^{2}$.

BM’nin özel bir kurumu olan Birleşmiş Milletler Eğitim, Bilim ve Kültür Örgütünün (United Nations Educational, Scientific and Cultural Organization/UNESCO) sürdürülebilir kalkınma hedefleriyle bağlantılı olarak saptadığı küresel önceliklerinden biri de eğitimde toplumsal cinsiyet eşitliğinin sağlanmasıdır. Bu amaçla UNESCO kız çocuklarının ve kadınların eğitiminin teşvik edilmesi, toplumsal dönüşümün özneleri olarak kadınların teşvik edilmesi, kadınların kültürel hayata tam katılımının sağlanması gibi öncelikler belirlemiştir. Ayrıca okulla bağlantılı toplumsal cinsiyet temelli şiddetin her türüyle mücadele de eğitimin önceliklerindendir. Toplumsal cinsiyet eşitliğinin sağlanması hedefi UNESCO’nun tüm faaliyetleriyle bütünleşik hale getirerek desteklediği bir hedeftir ${ }^{3}$. Eğitimde eşitlik ile kastedilenin sadece eğitime eşit erişim olmadığını da vurgulamak gerekir. Eğitimin adil, nitelikli, kapsayıcı ve toplumsal cinsiyet eşitliğine dayalı olması gerekir ${ }^{4}$.

Eğitim denildiğinde akla ilk olarak ilköğretim kademesi ve devamındaki süreçler gelir. Ancak üniversitelerin hem kurumsal olarak hem de ürettikleri bilgi itibariyle ataerkil sistemin dışında olmadıkları düşünüldüğünde, lisans düzeyindeki eğitimin, özellikle de ataerkil yapının sürmesinde belirgin bir rol oynayan hukuk eğitiminin de toplumsal cinsiyet perspektifiyle ele alınması gerekliliği ortaya çıkar.

Bu çalışma, yukarıda belirtilen gerekliliklerden hareketle belirli bir Hukuk Fakültesi'nde ders veren ve kendi alanları açısından toplumsal cinsiyetle ilgili sorunlar olduğunu düşünen yazarların bir araya gelmesiyle ortaya çıkmıştır. Her alt bölümde yazarlar kendi alanlarına ilişkin belirli temel

1 "Goal 5: Achieve gender equality and empowerall women and girls", <https://www.un.org/sustainabledevelopment/ gender-equality/> Erişim Tarihi 13 Eylül 2021.

2 Bkz. Goal 5. Ayrıca Covid-19 sürecinin, sınırlı sayıdaki olumlu gelişmeyi de tersine çevirebileceği ve varolan eşitsizlikleri daha da derinleştirebileceğine dikkat çekilmiştir.

3 UNESCO moving forward the 2030 Agenda for Sustainable Development, <https://en.unesco.org/creativity/sites/ creativity/files/247785en.pdf> Erişim Tarihi 13 Eylül 2021.

4 UNESCO moving forward the 2030 Agenda for Sustainable Development. 
sorunlara yoğunlaşmış olup, alana ilişkin tüm soruları içerme ve tüm tartışmaları tüketme iddiası taşımamaktadırlar. Çalışmada öncelikle toplumsal cinsiyet kavramı ve hukuk ile ilişkisine ilişkin çerçeve çizilmekte, ardından seçilen alanlarda toplumsal cinsiyetle ilgili görülen belirli sorunlar tartışılmaktadır.

\section{TOPLUMSAL CINSIYET VE HUKUK EĞiTiMi}

\section{A. TOPLUMSAL CINSIYYT SORUNU}

Sözlük anlamıyla toplumsal cinsiyet, biyolojik farklardan ziyade toplumsal ve kültürel farklara göre erkek veya kadın olarak görülmeye işaret eder ${ }^{5}$. Bununla birlikte biyolojik cinsiyet (sex) ve toplumsal cinsiyet (gender) kavramlarının farklı feminist teorisyenlere göre farklı şekillerde ele alındığını, günümüzde cinsel yönelim ve cinsiyet kimliğinin toplumsal cinsiyetle ilişkilendirildiğini ve kavramın kendisinin de farklı açılardan tartışıldığını belirtmek gerekir6.

Hukuk sistemimiz açısından bakıldığında ise toplumsal cinsiyet kavramı kadın ve erkek kavramlarıyla sınırlı olarak kullanılmakta ve İstanbul Sözleşmesi’ndeki toplumsal cinsiyet kavramı buna kaynaklık etmektedir ${ }^{7}$. Tam adı Kadına Yönelik Şiddet ve Aile İçi Şiddetin Önlenmesi ve Bunlarla Mücadeleye Dair Avrupa Konseyi Sözleşmesi ${ }^{8}$ olan, kısaca İstanbul Sözleşmesi olarak ifade edilen Sözleşme’nin 3. maddesi toplumsal cinsiyeti herhangi bir toplumun, kadınlar ve erkekler için uygun olduğunu düşündüğ̈̈ sosyal anlamda oluşturulmuş roller, davranışlar, faaliyetler ve özellikler” olarak tanımlar. Ne yazık ki, diğer pek çok toplumsal yapıda olduğu gibi hukuk da ataerkil bakış açısını yansıtır ve sürekli yeniden üretir. Tarihi süreci gözden geçirdiğimizde hukuk normlarının hem türetilmesinde hem de uygulanmasında toplumsal cinsiyet rolleri ve kalıplarının devreye girdiğini görmekteyiz. $\mathrm{Bu}$ durum hukuk ile toplumsal cinsiyet ilişkisinin gözden geçirilmesini gerekli kılar.

Toplumsal cinsiyetin sorunsallaştırılması; bireylerin cinsiyetlerine göre onlara toplumsal ve kültürel olarak farklı roller yüklenmesinin sorgulanması, kişinin ait olduğu kabul edilen toplumsal cinsiyetine göre belirli avantajlara sahip olmasının ya da dezavantajlı olmasının deşifre edilmesi, feminist teori sayesinde mümkün olmuştur. Bu çabanın hukuk alanındaki yansımaları da Feminist Hukuk

5 <https://www.oxfordlearnersdictionaries.com/definition/english/gender?q=gender> Erişim tarihi 13 Ağustos 2021; Kavramı kullanan sosyolog Ann Oakley, biyolojik bir kavram olan cinsiyetten farklı olarak toplumsal cinsiyetin psikolojik ve kültürel bir kavram olduğu tespitini yapmıștır. Erkek ya da kadın, oğlan ya da kız olmak, belirli bir cinsel organa sahip olmak kadar, giyimin, jestin, mesleğin, sosyal ağın ve kişiliğin bir işlevidir. Ann Oakley, Sex, Gender and Society (Gower Publishing 1985) 158.

6 Mari Mikkola, 'Feminist Perspective on Sex and Gender', (Stanford Encyclopedia of Philosophy Fall 2019 edition), Edward N. Zalta (ed.), <https://plato.stanford.edu/archives/fall2019/entries/feminism-gender/> Erişim Tarihi 13 Ağustos 2021.

7 Gülriz Uygur, Nadire Özdemir, 'Giriş’ iç Gülriz Uygur, Nadire Özdemir (edr), Hukuk ve Toplumsal Cinsiyet Çalışmaları (Seçkin 2018) 7. Sözleşmenin 3. maddesindeki tanımdan hareket edilmesi toplumsal cinsiyet kavramının hukuk literatüründe yerleşik hale geldiği ve mahkeme kararlarında dikkate alındığı anlamına gelmemektedir. Aksine kavram hem hukuk literatüründe hem de uygulamada nadiren kendine yer bulur. Bkz. Uygur, Özdemir 7.

8 Kadına Yönelik Şiddet ve Aile İçi Şiddetin Önlenmesi ve Bunlarla Mücadeleye İlişkin Avrupa Konseyi Sözleşmesi 11.5.2011 tarihinde imzaya açlmış ve 1.8.2014 tarihinde yürürlüğe girmiştir. Sözleşme Türkiye’de 1.8.2014 itibariyle yürürlüğe girmiş, 1.7.2021 tarihi itibariyle Türkiye Sözleşme’den geri çekilmiştir. Sözleşme metni için bkz. < https:// rm.coe.int/168.046.2545> Erişim Tarihi 14 Ağustos 2021. 
Teorisini ${ }^{9}$ şekillendirmiştir. $1980^{\prime}$ li yllardan itibaren gelişen bu teorinin önde gelen isimlerinin birçoğunun, 1960'll yıllarda hukuk fakültelerinde öğrenci olan ve o yılların toplumsal hareketlerinde yer alan feministler olduğu ve aldıkları hukuk eğitiminde topumsal cinsiyetin bir sorun olarak ele alınmamasından hareketle, teorik düzeyde ve uygulamada hukuk ve toplumsal cinsiyet sorununu bir arada ele almaya başladıkları görülmektedir ${ }^{10}$.

Yukarıda da belirtildiği üzere, bugün feminist teorinin kendi içinde toplumsal cinsiyete ilişkin yaklaşımlar farklılık gösterse de, kişinin toplumsal cinsiyeti nedeniyle üstün ya da aşağı görülmesi ve sahip olduğu haklardan yararlanıp yararlanamaması sorunu, feminist çalışmaların toplumsal cinsiyet eşitliğini hedefleyen sorgulamaları sayesinde gündeme gelmiştir.

Türkiye açısından bağlayıcı olan temel insan hakları sözleşmelerinden biri BM Kadına Karşı Her Türlü Ayırımcilığın Önlenmesi Sözleşmesidir (CEDAW) ${ }^{11}$. CEDAW, devletlerin alması gereken önlemler arasında yasal önlemlerin yanı sıra, şu hususu vurgular: "Her iki cinsten birinin aşağı veya üstün olduğu fikrine veya erkekler ile kadınlarm basmakalıp rollere sahip oldukları düşüncesine dayanan bütün önyargllar ve gelenekler ile her türlü uygulamay tasfiye etmek amaclyla erkeklerin ve kadınların sosyal ve kültürel davranış tarzlarını değiştirmek;" (CEDAW m.5/a).

Sözleşme’nin eğitim hakkına ilişkin düzenlemesinde de aynı hususa dikkat çekildiğini görürüz: "Erkeklerin ve kadınların kahplaşmış rolleriyle ilgili kavramların eğitimin her düzeyinden ve biçiminden tasfiye edilmesi için karma eğitim ve bu amaca ulaşılmasına yardımcı olacak diğer eğitim türleri teşvik edilir ve özellikle okul kitapları ve ders programları gözden geçirilir ve bu öğretim metoduna göre uyarlanir." (CEDAW m.10/c).

Toplumsal cinsiyete dayalı şiddetle mücadelede eğitimin rolüne vurgu yapan İstanbul Sözleşmesi’nde de eğitimin niteliğine ilişkin olarak devletlere şu yükümlülük yüklenmektedir: "Taraflar, yerine göre, tüm eğitim seviyelerinde resmi müfredata, kadın erkek eşitliği, toplumsal klişelerden arındırılmış toplumsal cinsiyet rolleri, karşıllklı saygi, kişisel ilişkilerde çatışmaların şiddete başvurmadan çözüme kavuşturulmasl, kadınlara karşı toplumsal cinsiyete dayalı şiddet ve kişilik bütünlüğ̈̈ne saygı gibi konuların, öğrencilerin zaman içinde değişen öğrenme kapasitelerine uyarlanmış bir biçimde dâhil edilmesi için gerekli tedbirleri alacaklardir." (İstanbul Sözleşmesi m. 14).

Görüldüğü üzere, toplumsal cinsiyet eşitsizliği temel haklardan faydalanmayı engelleyen bir insan hakları sorunudur ve toplumsal cinsiyete dayalı roller ve kalıp yargılarla mücadele etmek devletlerin yükümlülüklerindendir. $\mathrm{Bu}$ mücadelenin başlıca araçlarından biri eğitimdir ve eğitimin her kademesinde söz konusu yükümlülük geçerlidir. Hukuk eğitimini de süreçten ayrı düşünemeyeceğimiz için, bu aşamada da toplumsal cinsiyet eşitliğine dayalı bir dönüşüm bir yükümlülük olarak karşımıza çıkmaktadır.

9 Feminist Hukuk Teorisi için, kavramı ilke kez kullanan Ann Scales'in Türkçe’ye çevirilmişşu eserine bakılabilir: Hukuki Feminizm: Aktivizm, Savunma ve Hukuk Kuramı (Dost 2019).

10 Fatma İrem Çağlar Gürgey, “Feminist Hukuk Kuramı’ Nedir?' (2014) 1(5) Hukuk Kuramı 28, 29-30.

11 BM Kadına Karşı Her Türlü Ayrımcılığın Ortadan Kaldırılması Sözleşmesi 1.3.1980 tarihinde imzaya açılmış ve 3.9.1981 tarihinde yürürlüğe girmiştir. Türkiye bakımından Sözleşme 19 Ocak 1986 tarihinde yürürlüğe girmiştir. 
Toplumsal cinsiyet rolleri ve cinsiyetçi kalıpyargılar hukuk sistemi içinde oluşturulur ve hukuk aracılığıyla pekiştirilerek, ayırımcılığa ve insan hakları ihlallerine yol açar. Bu roller ve kalıpyargılar nedeniyle kişilerden, cinsiyetlerine göre belirli şekillerde davranmaları ve davranmamaları ya da belirli rolleri üstlenmeleri beklenir. Bu beklentiler, eşit muamele görmemeye ve ayırımcılığa yol açar $^{12}$. Aşağıdaki bölümlerde, hukuk fakültelerinde okutulan bazı dersler açısından cinsiyet rollerine ve kalıpyargılara dayalı norm ve uygulama örnekleri tartışılmaktadır.

Hukuk eğitimi alan öğrencilerin avukatlık, hâkimlik, savcılık, idari çalışan, meclis ve hükümet üyesi ve benzeri çok geniş yelpazede yer alan mesleklerde aktif rol alacakları ve etkin olacakları düşünüldügünde, hukuka toplumsal cinsiyet açısından bakmanın önemi daha da anlaşılır hale gelir.

\section{B. HUKUK EĞiTIMINDE TOPLUMSAL CINSIYET PERSPEKTIFININ AKTARILMASI}

Dünyada giderek yaygınlaşan eğilim, her disiplinin toplumsal cinsiyet ekseninde gözden geçirilmesi ve kurumların bir toplumsal cinsiyet politikasının olmasıdır. Bu sürecin temelinde mevcut toplumsal yapıların cinsiyetçi olması ve bazen doğrudan bazen ise dolaylı olarak toplumsal cinsiyete dayalı ayırımcılığa neden olmaları yatmaktadır. Ürettikleri bilgiyi toplumla paylaşan üniversitelerin toplumsal cinsiyete ilişkin bir politika belgesinin olması tam da bu nedenle gereklidir. Aynı nedenle hukuk fakültelerinin de toplumsal cinsiyete ilişkin politika belgelerinin olmasının zaruri olduğu vurgulanir.

Toplumsal cinsiyet eşitliğinin hukuk eğitiminde anaakımlaştırılması (mainsteraming), kurumsal, pedagojik ve eğitimle ilgili değişimleri gerektirir: Tüm materyallerin toplumsal cinsiyete duyarlı bir bakış açısıyla gözden geçirilmesi, içerikteki kalıp yargıların ve önyargıların açığa çıkarılması, akademisyenler ve öğrenciler arasında mevzuatı ve hukukun belirli alanlarını yorumlarken toplumsal cinsiyete duyarlı bir yaklaşımın geliştirilmesi gerekir ${ }^{13}$. Toplumsal cinsiyete duyarlı bütçeleme ile bu konudaki çalışma ve projelerin desteklenmesi ve toplumsal cinsiyetle ilgili derslerin de açılması gereklidir $^{14}$.

Hukuk eğitiminin toplumsal cinsiyete duyarlı hale getirilmesi için, ders içeriklerinde, mevzuat kullanımında ve derslerde kullanılan yöntemlerde şu hususlara dikkat edilebilir ${ }^{15}$ :

- Derslerde toplumsal cinsiyet kavramını tanımlamak,

12 Bu konudaki örnekler için bkz. Aslı Şimşek, 'Bir İnsan Hakları İhlali ve Ayırımcılık Biçimi Olarak Toplumsal Cinsiyet Rolleri ve Kalıpyargılar: CEDAW Çerçevesinde Bir İnceleme’ (2020) 11(2) İnönü Üniversitesi Hukuk Fakültesi Dergisi 496-513.

13 Dragica Vujadinovic,'“Gender Mainstreaming in Law and Legal Education', (2015) 3 Belgrade Law Review, 63, https:// www.researchgate.net/publication/314484835_Gender_mainstreaming_in_law_and_legal_education Erişim Tarihi 1 Ağustos 2021.

14 ibid. 63.

15 Bu konuda tartışma ve öneriler için bkz. Gülriz Uygur, Nadire Özdemir, 'Hukuk eğitiminde Toplumsal Cinsiyet Eşitliğine İlişkin Problemler ve Çözüm Önerileri: Etik Temelde Bir Arayış-Dönüşüm İlkesi I’ iç Gülriz Uygur, Nadire Özdemir (edr), Hukuk ve Toplumsal Cinsiyet Çalışmaları (Seçkin 2018) 
- Derste kullanılacak materyalleri seçerken, o materyali toplumsal cinsiyet açısından gözden geçirmek; toplumsal cinsiyete dayalı önyargılarla yazılmış materyalleri mümkün olduğunca önermemek/kullanmamak; kullandığımız materyallerde bu tür önyargılar ve cinsiyetçi ifadeler yer almaktaysa, sorunlu hususlara dikkat çekmek,

- CEDAW ve İstanbul Sözleşmelerini baştan sona inceleyerek, kendi çalışma alanımızla ilişkili konu başlıklarını belirlemek ve bu konu başlıklarını anlatırken ilgili Sözleşmelerin hükümlerine yer vermek, somut olaylarla bağlantılar kurarak değerlendirmeler yapmak, Sözleşme gereklerinin ve devlete yüklediği yükümlülüklerin üzerinden geçmek,

- Anayasa m. 10'da düzenlenen eşitlik ilkesinin uzmanlık alanımız açısından ve toplumsal cinsiyet eşitliği bağlamında doğurduğu sonuçları düşünmek ve derslerde bu konuya yer vermek, somut örneklerle değerlendirmeler yapmak,

- Derslerimizde, ele aldığımız konuda toplumsal cinsiyete dayalı önyargıları örneklendirerek farkındalık yaratmayı amaçlamak,

-.Kendi alanımızda kullandığımız mevzuatın toplumsal cinsiyet eşitliğiyle ilgili hükümlerini derslerde ele almak,

- Grup çalışmalarında, ödevlerde, pratik çalışmalarda vb., toplumsal cinsiyet eşitliğiyle ilgili konular/ kararlar seçmek,

- Sınav sorularını toplumsal cinsiyet eşitliğini gözeterek hazırlamak (örneğin sorularda cinsiyetçi, ayırımcı ifadelere yer vermemek),

- Kurgusal davalar hazırlarken toplumsal cinsiyet eşitliği meselesini de dikkate almak, kurgu olayları toplumsal cinsiyet eşitliği duyarlılı̆̆ı ile kaleme almak,

- Hukuk kliniklerinde toplumsal cinsiyet eşitsizliğiyle ilgili çalışmalar yapmak,

- Dersler sırasında cinsiyetçi dil kullanmamak ve derse katılanların kullanması durumunda müdahale etmek,

- Öğrencilerin derse katılımında toplumsal cinsiyet eşitliğini gözetmek ve katılımları için onları cesaretlendirmenin yollarını aramak.

\section{INCELENEN DERSLER}

\section{A. MEDENI HUKUK}

\section{GENEL OLARAK}

1926 tarihli Türk Medeni Kanunu her ne kadar dönemi için eşitlikçi bir kanun olarak kabul edilse $\mathrm{de}^{16}$ kadın erkek eşitliğini gerçek anlamda sağlamaktan uzak kalmıştır ${ }^{17}$. Bunu gören kanun

16 Ahmet Kılıçoğlu, 'Medeni Kanun Açısından Kadın-Erkek Eşitliği' (1991) (1) Ankara Barosu Dergisi 9, 10.

17 Murat Develioğlu, 'Rupture d'égalité entre hommes et femmes autour de la question du nom de famille en Turquie' (2013) 65(4) Revue Internationale de Droit Comparé 859, 860. Yazar özellkle kadının soyadı konusunda eşitliği sağlayamadığını belirtilmektedir. 
koyucu 2002 yllında kabul edilen 4721 sayılı Türk Medeni Kanunu ile bu eşitsizliği ve değişen hayat koşullarını da dikkate alarak daha modern bir yapıya geçmeye çalışıı̧tır. Hâlihazırda Medeni Hukuku oluşturan kişiler hukuku, aile hukuku, miras hukuku ve eşya hukuku olmak üzere dört alana bakıldığında aile hukuku alanında kadın erkek eşitliğine aykırı düşebilecek kanuni düzenlemelerin hala mevcut olduğu; diğer üç alan açısından kanunda kadın veya erkek olarak bir ayırım yapılmadığ 1 ve kişilerin, cinsiyetlerinden bağımsız olarak malik, zilyet, mirasçı, mirasbırakan gibi ayırımlara tabi tutulduğu görülmektedir. Diğer bir ifade ile örneğin eşya hukuku alanında kanun tarafından malikin kadın veya erkek olması arasında bir ayırıma gidilmediği gibi miras hukukunda da mirasçının veya mirasbırakanın kadın veya erkek olması arasında da bir ayırım yapılmamış ve farklı düzenlemelere tabi tutulmamıştır.

Bununla birlikte, özellikle ataerkil toplumlarda, kişilerin erkekler lehine avantajlı durumlar yaratmak amacıyla farklı yollara başvurduğu da bir gerçektir. Sözgelimi, az önce de ifade edildiği üzere, miras hukukunda yer alan normlar arasında kadın erkek eşitliğini bozacak hükümler yer almamaktadır. Diğer bir ifadeyle, mirasçılık sıfatına sahip sağ kalan eşin kadın veya erkek olması arasında bir fark yoktur. Bunun gibi, Kanunda saklı paya da sahip olan altsoyun kız veya erkek çocuk olması arasında da bir ayırım gözetilmemiştir. Ancak buna rağmen bu alanda erkeklerin menfaatine hizmet eden uygulamaların bulunduğu ve bu durumun zaman zaman mahkeme kararlarına dahi yansıdığı görülmektedir. Örneğin özellikle muris muvazaasının yapılmasına neden olan durumların başında, mirasbırakanın erkek çocuklarını kız çocuklarından üstün tutma çabası gelmektedir ${ }^{18}$. Bunun sebebi mirasbırakanın soyadını devam ettirme isteği veya malvarlığının yönetimini daha iyi yapacağına olan inanç olabileceği gibi ailenin malvarlığını erkeğin yöneteceğine olan inanç da olabilmektedir. Ataerkil toplumlarda sıklıkla karşılaşılan bu inançla mirasbırakanlar kız evlatların buna itiraz etmesini önlemek için muvazaa yoluna gitmektedir. Görüldüğü gibi her ne kadar kanun özelinde eşitliğe aykırı bir düzenleme yoksa da mirasbırakanın bu saiklerle taşınmazını oğulları ya da oğullarından olma erkek torunlarına temlik ettiği Yargıtay kararlarında da sıklıkla görülmektedir ${ }^{19}$. Yargıtay İçtihadı Birleştirme Kararı uyarınca verilen bir kararda eşitliğe aykırı bu tür davranış için bir çözüm getirilmiştir. Kararda durum şu ifadelerle özetlenmişti: “...Bu karar toplumun özel koşul ve gereksinimleri dikkate alınarak çıkarılmıştır. Şöyle ki, özellikle küçük kırsal bölgelerde

18 Selin Sert Sütçü, Miras Bırakanın Muvazaah Hukuki İşlemleri ve Sonuçları (1. Baskı, Seçkin 2018) 69; Eraslan Özkaya, Açıklamalı - İçtihatlı İnançlı İslem ve Muvazaa Davaları (7. Baskı, Seçkin 2017) 427.

19 Yargitay 1 HD, E 2016/14919 K 2019/6764, 19.12.2019: “... miras birakan tarafindan adına kayıtlı iki parça taşınmazın davalı oğluna ölünceye kadar bakma akdi ile 13.08.1999 ve 04.08.2009 tarihlerinde devredildiği, 13.08.1999 tarihinde yapılan ilk temlikle bakım borcunun yerine getirilmesinin taahhüt altına alındiğı, miras birakan adına kayıtlı olan ve mirasçılarına intikal eden başkaca taşınmazın bulunmadiğı, temliklerden davacının haberinin olmadiğı, miras bırakanın uzun süre birlikte yaşadı̆̆ı davalı oğlunu kayırmak suretiyle tüm malvarlığın davalıya devrettiği, ikinci temlik ile makul sınırın aşıldığı toplanan tüm deliller yukarıdaki ilkeler uyarınca irdelendiğinde 139 parsel sayıl taşınmazın devrinin mirasçılarından malların kaçırılması gaysesiyle ve muvaza içerdiği neticesinde varılmıştır. Yargıtay Bilgi Bankası <https:// karararama.yargitay.gov.tr/YargitayBilgiBankasiIstemciWeb/>, Erişim Tarihi 24.12.2020. Yargitay 1 HD, E 2016/12480 K 2019/638, 10.12.2019: “...miras birakan ...un halen hayatta 10 kızı ve tek oğlu varken dava konusu tek taşınmazını davalı oğlu ve gelinine temlikinde bakıp gözetilme koşulunu değil de diğer mirasçılarından mal kaçırma düşüncesini ön planda tuttuğu ve bu iradeyle işlemi gerçekleştirdiği, bakım ve gözetim amacını taşınmazın bir kısmını vermek suretiyle de gerçekleştirebileceği sonuç ve kanaatine varılmaktadır. Muris muvazaası hukuksal nedenine dayalı tapu iptali-tescil isteğine ilişkin davanın kabulüne karar verilmesi gerekir”. Yargıtay Bilgi Bankası <https://karararama.yargitay.gov.tr/ YargitayBilgiBankasiIstemciWeb/>, Erişim Tarihi 24.12.2020. 
kız çocuklarımı mirastan mahrum etmek amacıyla muris, erkek çocuğu ile anlaşarak gerçekte bă̆ı̧̧lama istediği malvarlığını, kötüniyetle satış göstermek suretiyle devir işlemini gerçekleștirmektedir. (...)

Iște, 1974 tarihli $\dot{I B K}$ esas itibariyle muvazaalı tasarruflar karşısında gerek kız çocukların erkek çocuklarla eşit miras hakkına kavuşturmak ve gerekse murisin çocukları arasında eşitliği sağlamak amacıyla çıkarılmış olup, bu düzenlemenin toplumun ihtiyaçlarına cevap verdiği ve hukuk önünde eşitliği sağladığı tartışma götürmeyecek kadar açıktır. Bu çözüm tarzının değiştirilmesini haklı kllacak hiç bir neden görülmemiştir ${ }^{20 "}$.

Görülüyor ki, kimi zaman hukuk normlarının eşitlikçi olması da yeterli olmayabilmekte, bu konuda kanunu dolanarak yaratılan eşitsizliklere karşı mahkemelerin müdahalesine de ihtiyaç olabilmektedir. Ancak aşağıda detaylarıyla görüleceği üzere mahkemelerin bu konudaki hassasiyetine de her zaman rastlamak mümkün olmamaktadır ${ }^{21}$.

Türk Medeni Kanunu açısından genel bir değerlendirme yapıldığında kadın erkek eşitliği konusunda önemli adımların atıldığı ve geçmişte ciddi farklılıklar yaratan birçok hükmün 4721 sayılı Medeni Kanun’un kabulü ile yürürlükten kalktığı açıkça görülmektedir. Buna karşılık günümüzde medeni hukukta tam bir eşitliğin sağlandığını söylemek de güçtür. Özellikle eşitliğe aykırılık teşkil eden hukuk normlarına bakıldığında, kaynak İsviçre Kanununda bu konuların birçoğunda zaman içerisinde olumlu değişikliklere gidilmiş olsa da Türk Medeni Kanununda aynı hızla değişim ve bu konuda bir iyileştirmeye gidilmediği de görülmektedir.

Çalışmada öncelikle Türk Medeni Kanunu’ndaki hukuk normları açısından aykırı olduğu görülen hükümlere yer verilecek, olanak bulunduğu ölçüde kısaca Yargıtay ve Anayasa Mahkemesinin eşitliğe gölge düşürecek söylem ve kararlarından örnekler verilerek durum hakkında bilgi verilmeye çalışılacaktır. Bu konudaki açıklamalara geçmeden önce belirtmekte fayda vardır ki, toplumsal cinsiyet eşitliğine aykırılıklara ilişkin verilecek olan durumlar çalışmada sayılanlar ile sınırlı değildir. Çalışmada sadece özellikle derslerin işlenişi sırasında öğrencilerin dikkatine sunulması önemli olan temel aykırılıklar kaleme alınmaya çalışılmıştır.

\section{MEDENI HUKUK NORMLARI BAKIMINDAN GENEL DEĞERLENDIRME}

Hukuk normlarına geldiğimizde medeni hukuk alanında kadın erkek eşitliğine aykırı kanun hükümlerin gerek geçmişte gerek günümüzde en çok rastlandığı alanın aile hukuku olduğunu söylemek gerekir. 1926 yllında kabul edilen Medeni Kanun'da aile hukuku alanında kadın erkek eşitliğine aykırılık teşkil edecek birçok hüküm bulunmaktaydı. Zamanla Anayasa Mahkemesi tarafından eşitliğe aykırı olduğu gerekçesiyle bu kanun maddelerinin birçoğu iptal edilmiştir. 2002 yılında da 4721 Sayılı Türk Medeni Kanunu kabul edilirken iptal edilen bu maddeler ve İsviçre’deki

20 Yargıtay İçtihadı Birleştirme Kararı E 1989/1, K1990/2, 16.3.1990.

21 Yargı organlarının kimi zaman geleneksel cinsiyet rollerini önde tutarken kimi zaman eşitlikçi normların hayata geçirilmesine katkı sağladığı yönünde bkz. Özgün Çelebi, 'Toplumsal Cinsiyet Eşitliği Bağlamında Kadının Soyadı Ve Soyadının Çocuğa Aktarımı’ (2019) (2) Galatasaray Üniversitesi Hukuk Fakültesi Dergisi 537, 540. 
gelişmeler dikkate alınarak eşitliğe aykırı olan birçok hükme artık kanunda yer verilmemiştir ${ }^{22}$. Ancak ne yazık ki kabul edilen bu Medeni Kanun ile de toplumsal cinsiyet eşitliğinin tam olarak sağlandığını söylemek mümkün değildir. Özellikle soyadı ${ }^{23}$, soybağı ve kadın için bekleme süresi gibi konularda kadın erkek eşitliğinin sağlanabildiğini söylemek oldukça güçtür.

\section{a. Soyadı Bakımından Değerlendirme}

Türk Medeni Kanunu’nun "Kadının soyadı " kenar başlıklı 187. maddesi ${ }^{24}$ uyarınca: "Kadın, evlenmekle kocasinin soyadin alı; ancak evlendirme memuruna veya daha sonra nüfus idaresine yapacağı yazılı başvuruyla kocasının soyadı önünde önceki soyadın da kullanabilir ${ }^{25}$. Daha önce iki soyadı kullanan kadın, bu haktan sadece bir soyadı için yararlanabilir." Madde metnine bakıldı̆̆ında genel olarak kullanılan kişi, birey, eş gibi terimler yerine "kadın ve erkek" terimlerinin tercih edildiği ve böylelikle söylemde bir ayırımcılığa gidildiği net bir biçimde görülmektedir. Söz konusu madde, 2013 yılında değişikliğe uğramadan önceki İsviçre Medeni Kanunu’nun 160. maddesine denk gelmekteydi ${ }^{26}$. Bununla birlikte hâlihazırda üç fikradan oluşan İsviçre Medeni Kanun’un 160. maddesi cinsiyet ayırımcılığı içeren bu maddeden ayrılmıştır. Anılan hüküm uyarınca her eş kendi soyadını korur. Bununla birlikte, müstakbel eşler, aile soyadı olarak gelinin veya damadın soyadını taşımak istediklerini nüfus müdürlüğüne beyan edebilirler. Müstakbel eşler soyadlarını muhafaza ettikleri takdirde, çocuklarının hangi soyadlarını taşıyacaklarına kendileri karar verirler. Haklı hallerde nüfus memuru, müstakbel eşleri bu yükümlülükten kurtarabiliir ${ }^{27}$. Görüldüğü üzere İsviçre kanun koyucusu bu konuda cinsiyet ayırımcılığına izin vermeyen eşitlikçi bir hüküm getirerek eski uygulamasından vazgeçmiştir ${ }^{28}$.

Avrupa İnsan Hakları Mahkemesi, 2004 tarihli Ünal Tekeli kararında Türk Medeni Kanunu’nun 187. maddesinin eşitlik ilkesine aykırı olduğuna karar vermiş ve Türkiye aleyhine tazminata

22 Evlenme yaşı, yerleşim yeri, velayet hakkının yürütülmesi, kadının çalışması, zina ve aile reisi ve benzeri konularında eşitliğe aykırı hükümler yürürlükten kalkmıştır.

23 Kadının soyadına ilişkin düzenlemelerin ve AHİS, Anayasa, CEDAW ve MÖHUK kapsamında detaylı değerlendirilmesi için bkz. Nuray Ekşi, 'Medeni Kanunun Kadının Soyadına İlişkin Hükmünün AİHS, Anayasa, Cedaw ve Möhuk Kapsamında Değerlendirilmesi' (2012) Yeditepe Üniversitesi Hukuk Fakültesi Dergisi Özel Sayıs1, 2011/II - 2012/I, Prof. Dr. Erhan ADAL’a Armağan 311, 331.

24 Maddenin kadın-erkek eşitliği açısından detaylı değerlendirimesi hakkında bkz. Seda İrem Çakırca, 'Turkish Civil Code and CEDAW: Never Shall the Twain Meet?' (2015) 45(62) Annales de la Faculté de Droit d'Istanbul 145, 192.

25 Develioğlu (n 17) 860. Yazar sonradan eklenen bu fikranın da eşitliği tam anlamıyla sağlayamadığını ifade etmektedir. Nitekim halihazır hükümler kocasının rızası olsa dahi aile soyadı olarak kadının soyadını seçmeye imkan vermemektedir.

26 Belirtmekte fayda vardır ki söz konusu değişikliğe temel oluşturan kanun 30.09.2011 tarihli Federal Kanun olmuştur.

27 İsviçre’de 2013 yılında yürürlüğe giren değişiklikler ve Türkiye'deki durum hakkındaki detaylı değerlendirme için bkz. Saibe Oktay Özdemir, 'Soyadı ve ile İlgili İsviçre Medeni Kanunu’nda 2013 Yılında Yürürlüğe Giren Değişiklikler ile Türk Hukukundaki Durumun Karşılaştırılması’ (2016) 22(3) Marmara Üniversitesi Hukuk Fakültesi Hukuk Araştırmaları Dergisi 2017, 2032.

28 Belirtmekte fayda vardır ki İsviçre’ye nazaran Almanya bu konudaki eşitlikçi bakış açısını çok daha evvel, 1993 yılında kabul ettiği aile adıyla ilgili yasayla ortaya koymuştur. Ayrıca kanun artık evli çiftlerin ortak bir aile soyadı seçme zorunluluğunu da kaldırmış böylelikle eşlerin bu konuda anlaşamaması ihtimalinde kadın veya erkekten yana bir tercih yapmak zorunda da kalmamıştır. Konu hakkında detaylı bilgi için bkz. Nazan Moroğlu, 'Kadının Kimlik Sorunu: Kadının Soyadı' (2012) Türkiye Barolar Birliği Dergisi 245, 248. 
hükmetmiştir ${ }^{29}$. Türkiye aleyhine verilen bu karara rağmen hâlihazırdaki kanun maddesinde bir değişiklik yapılmamış; hatta 10.03.2011 tarihinde, anılan hükmün eşitlik ilkesine aykırı olduğu iddiasını inceleyen Anayasa Mahkemesi şu açılamalara dayanarak maddenin eşitlik ilkesine aykırılık oluşturmadığına hükmetmiştir:“(...) yasakoyucunun aile soyadı konusundaki takdir hakkını, aile birliği ve bütünlüğ̈̈nün korunması ve aile bağlarının güçlendirilmesi başta olmak üzere, kamu yararı ve kamu düzeninin gerektirdiği kimi zorunluluklar nedeniyle, eşlerden birisine öncelik tanıyacak biçimde kullanmasının hukuk devletine aykırı bir yönü bulunmamaktadır. Kaldı ki itiraz konusu kuralda kadının başvurusu durumunda önceki soyadını kocasının soyadının önüne ekleyerek kullanabileceği belirtilerek, kişilik hakkı ile kamu yararı arasında adil bir dengenin kurulması da sağlanmiştır.

Kadının evlenmekle kocasının soyadını almasının cinsiyet ayırımına dayanan bir farklılaşma yarattı̆̆ı savı da yerinde değildir. Durum ve konumlarındaki özellikler, kimi kişiler ya da topluluklar için değişik kuralları gerekli kılabilir. Belirtilen gerekçelerle yasakoyucunun takdir yetkisi kapsamında aile soyadı olarak kocanın soyadına öncelik vermesi eşitlik ilkesine aykııllk oluşturmamaktadır ${ }^{30}$."

Bununla birlikte, Anayasa Mahkemesine bireysel başvuru yolunun açılmasıyla konu 2014 yllında tekrar Anayasa Mahkemesinin önüne gelmiş ve Mahkeme, söz konusu madde ve uygulaması ile başvurucunun Anayasảnın 17. maddesinde güvence altına alınan manevi varlığın korunması ve geliştirilmesi hakkının, müdahalenin kanuniliği şartının yerine getirilmemesi nedeniyle ihlal edildiği sonucuna varmış ancak konuyu ayrıca Anayasảnın 10, 12 ve 90. maddelerinin ihlal edildiği yönünden değerlendirmeye gerek görmemiştir ${ }^{31}$. Diğer bir ifadeyle Anayasa Mahkemesi söz konusu maddeyi eşitliğe aykırılık yönünden incelememiştir. Tüm bu gelişmelere ve 17. maddenin ihlal edildiğine kanaat getirilmiş olmasına rağmen Medeni Kanunu’nun 187. maddesinde yine herhangi bir değişiklik yapılmamış, bu nedenle evlendikten sonra kadının sadece kendi soyadını tutabilmesi için mahkemeye başvurması gerekmiştir ${ }^{32}$. Yargitay Hukuk Genel Kurulu da 2014/889 esas, 2015/2011 karar numaralı ve 30.9.2015 tarihli bir kararında "Somut olaya gelince: sebep önemli olmaksızın davacı evlilik birliği içinde sadece kızlı soyismini kullanmak istemektedir. Kızlık soyisminin kullanmak istemek için hakl bir gerekçenin bulunmasına ihtiyaç bulunmamaktadır. Bu hak AİHS 8 ve Anayasanin 17. maddeleri kapsaminda bir insan hakkıdır ve cinsiyete dayali olarak bir ayrima tabi tutulmaksızın erkek ve kadın arasında eşit şekilde uygulanmalıdır. Aksi durum AİHS’nin 14. maddesine aykırılık teşkil edecektir" şeklinde açıllamada bulunarak evli kadının sadece evlenmeden önceki soyadını taşıyabileceğine hükmetmiştir. Görülüyor ki hâlihazır düzenleme kapsamında evli kadın haklı sebebe ihtiyacı olmasa da ancak mahkeme kararı ile kendi soyadını tek başına kullanabilmektedir. Hâlbuki eşit haklara sahip olabilme tıpkı İsviçre Medeni Kanun'daki mevcut düzenleme gibi bir hüküm getirilerek mümkün olur. Belirtmekte fayda vardır ki Yargitay İkinci Hukuk Dairesi anılan bu karardan kısa bir süre önce de "Mahkemenin gerekçesinde belirttĭği Anayasa

29 Ünal v Tekeli Türkiye App no 29865/96 (ECtHR, 16 November 2004).

30 Anayasa Mahkemesi GK, E. 2009/85 K. 2011/49 T. 10.3.2011.

31 Anayasa Mahkemesi 1.B., B. 2013/4439 T. 6.3.2014.

32 Serap Helvacı, 'Avrupa İnsan Hakları Mahkemesinin Ve Anayasa Mahkemesinin Kararları Işı̆̆ında Evli Kadının Soyadı' (2015) 35(1) MHB 157, 166-167. 
Mahkemesinin 19.12.2013 tarihli kararı bireysel başvuru sonucu verilmiş bir karar olup Anayasa mahkemesinin diğer kararları gibi bağlayıcı yanı yoktur Böyle bir yaklaşım "yürürlükte olan yasa hükmüne aykır kararlar verilmesi" sonucunu hasıl eder. Bu ise, Türk Medeni Kanununun benimsediği aile birliğinin ve bütünlüğünün kocanın soyadı üzerinden devamına ilişkin genel prensibi ve kamu düzenini bozar. Öyleyse davanın reddine karar verilmelidir. Açıklanan hususlar gözetilmeksizin yasal olmayan gerekçelerle yazıl şekilde karar verilmesi doğru bulunmamıştır" diyerek eşitliğe aykırı bakış açısını ve uygulamasını da sürdürmeye devam etmiştir ${ }^{33}$.

Kadın erkek açısından soyadı konusunda farklı düzenlemeye gidilmiş olmasının bir diğer dolaylı sonucu "IV. Boşanan kadının kişisel durumu" kenar başlıklı Medeni Kanun’un 173. maddesine yansımıştır. Nitekim evlenme ile kocasının soyadını alan kadının boşanma ile de bu soyadından vazgeçmesi beklenmektedir. Konuyu düzenleyen hüküm uyarınca: "Boşanma hâlinde kadın, (...), evlenmeden önceki soyadın yeniden alır. Eğer kadın evlenmeden önce dul idiyse hâkimden bekârlık soyadın taşımasına izin verilmesini isteyebilir. Kadının, boşandığı kocasının soyadın kullanmakta menfaati bulunduğu ve bunun kocaya bir zarar vermeyeceği ispatlanırsa, istemi üzerine hâkim, kocasının soyadını taşımasına izin verir. Koca, koşulların değişmesi hâlinde bu iznin kaldırılmasını isteyebilir". Görülüyor ki kanun koyucu kadına, sadece evlenmede tercih hakkı tanımamakla kalmamış, boşanmada da kadına bir tercih imkânı vermemiştir. Kadının boşandıktan sonra boşandığı kocasının soyadını kullanabilmesi için ya kocanın buna müsaade etmesi gerektiğini ya da bu soyadını kullanmada üstün menfaati olduğunu ispatlaması gerektiğini hükme bağlamıştır. Eşitliğe aykırılık teşkil eden bu hükmün yanı sıra Yargıtay da haklı sebep sayılan halleri oldukça dar yorumlayarak kadının bu konudaki mağduriyetini devam ettiren kararlar vermeye devam etmiştir. Örneğin, Yargıtay boşanan kadının velayet hakkı kendisine bırakılmış çocukları ile aynı soyadını kullanma isteğini haklı sebep olarak kabul etmemiştir ${ }^{34}$. Sonuç göstermektedir ki, gerek kanun gerekse Yargıtay boşanan kadının soyadını sadece soyadını veren erkeğin menfaatini dikkate alarak kadının kişilik hakları ile menfaatini ikinci plana atma eğilimindedir ${ }^{35}$. Tüm bu açıklamalar göstermektedir ki kadının medeni hal değişikliği erkeğinkinden farklı olarak kendiliğinden soyadının da değişmesine neden olmakta ve soyadının değişmezliği ilkesine de aykırı olarak sadece kadınlara özgü bir sorun olarak karşımıza çıkmaktadır ${ }^{36}$.

\section{b. Çocuğun Soyadı Bakımından Değerlendirme}

Anne ile babanın evli olduğu ihtimalde kadının da aile soyadı olarak kocasının soyadını alması gerektiğinden; çocuk da babanın soyadını almaktadır. Eşler anlaşarak dahi çocuğa geçecek soyadını değiştirememektedir ${ }^{37}$. Kadının evlenirken kocanın soyadının önünde kendi soyadını tutması da bu

33 Yargitay 2 HD, E 2014/16089 K. 2014/23993, 27.11.2014, <https://www.lexpera.com.tr/> Erişim Tarihi 30.09.2021.

34 Yargitay 2 HD, E 2015/12024 K 2015/13284, 23.06.2015, <https://www.lexpera.com.tr/> Erişim Tarihi 30.09.2021.

35 Çelebi (n 21) 569, Sera Reyhani Yüksel, 'Türk Medenî Kanunu Bakımından Kadın-Erkek Eşitliği’ (2014) 18 (2) Gazi Üniversitesi Hukuk Fakültesi Dergisi 175, 196.

36 Çelebi (n 21) 568.

37 Çelebi (n 21) 571; Deniz Ergene, İnsan Hakları Hukukundaki Gelişmeler Ișığında Türk Hukukunda Kadının ve Çocuğun Soyadı Meselesi ve Medeni Kanunda Değişiklik Önerisi' (2011) 31(2) Milletlerarası Hukuk ve Milletlerarası Özel Hukuk Bülteni 123, 139. 
durumu değiştirmemekte, çocuk hem annenin hem de babanın soyadını birlikte alamamaktadır ${ }^{38}$. Hâlihazır düzenlemeler eşlerin evli olduğu durumlarda çocuğun annesinin soyadını almasının mümkün olmadığını açıkça göstermektedir.

Evliliğin sona ermesi halinde kadının kendi soyadına dönmesi sonucu çocuğa da kendi soyadını verip veremeyeceği ise uzun bir süre boyunca bir başka tartışma konusu olmuştur ${ }^{39}$. Anayasa Mahkemesi 2525 Sayılı Soyadı Kanunu’nun 4. maddesinin ikinci fıkrasında yer alan "Evliliğin feshi veya boşanma hallerinde çocuk anasına tevdi edilmiş olsa bile babasının seçtiği veya seçeceği adı alır” hükmünü Anayasanın 10. ve 41. maddesine aykırılık teşkil ettiği için iptal etmiştir ${ }^{40}$. Anayasa Mahkemesinin bu konudaki kararı ne yazık ki ancak 2018 yılında Yargıtay tarafından benimsenebilmiş ve Yargıtay Hukuk Dairesi, 2018 yılında, boşanmış kadının velayeti kendisine verilmiş olan çocuğuna eğer onun üstün yararını ispat edebilirse 'kendi soyadının' verilmesini Aile Mahkemesinden talep edebileceğine karar vermiştir ${ }^{41}$. Belirtmekte fayda vardır ki Yargıtay burada durumu kadın erkek eşitliği açısından ele alarak değil çocuk açısından ve çocuğun üstün menfaati açısından değerlendirerek bu yönde bir karar vermiştir. Hâlbuki burada eşitliği esas alan kaynak kanun İsviçre veya Almanya gibi ülkelerdeki uygulama benimsenir ve evlenince eşlerin aile soyadı belirlenebileceği kabul edilirse; mahkemelerin, boşanma halinde çocuğun soyadı için anne veya baba arasında bir tercih yapmasına gerek olmayacak ve boşanmaya rağmen soyadında değişiklik yapılmasına gerek olmayacağı için çocuğun menfaati de bu durumdan zarar görmeyecektir ${ }^{42}$.

\section{c. Soybağı Bakımından Değerlendirme}

Türk Medeni Kanunu’nda kadın ve erkeklerin farklı uygulamaya tabi tutulduğu bir diğer alan ise soybağıdır. "Genel olarak soybağının kurulması" başlıklı Medeni Kanunu'nun 282. maddesi uyarınca çocuk ile ana arasında soybağı doğumla kurulurken çocuk ile baba arasında soybağı, ana ile evlilik, tanıma veya hâkim hükmüyle kurulmaktadır. Bu düzenlemeye göre erkek ile çocuk arasındaki soybağı açısından esas alınan kriter genetik miras iken kadın açısından genetik mirasa bakılmaksızın

38 Çelebi (n 21) 571; Burak Özen, 'Soyadının Soybağı Yoluyla Kazanılması ve Bu Yolla Kazanılan Soyadında Değişiklik Yapılması' (2010) 16(3-4) Marmara Üniversitesi Hukuk Fakültesi Hukuk Araştırmaları Dergisi 171, 174.

392002 yılına kadar olan gelişme ve tartışmalar hakkında detaylı bilgi için bkz. Haluk Nomer, 'Avrupa Birliği’ne Üye Devletlerde ve Türkiye'de Evlenen Kadının ve Ortak Çocuğun Soyadı' (2002) (22) Milletlerarası Hukuk ve Milletlerarası Özel Hukuk Bülteni 421, 450.

40 Anayasa Mahkemesi, E 2010/119 K 2011/165, 08.12.2011. Kararın detaylı incelemesi için bkz.Tuba Birinci Uzun, 'Aile Soyadı Çıkmazı - Anayasa Mahkemesi’nin Çocuğun Soyadının Velayeti Kendisine Bırakılan Annesi Tarafından Değiştirilmesi Hakkındaki 25 Haziran 2015 Tarihli ve 2013/3434 Başvuru Sayılı Kararının İncelenmesi' (2016) (4) Ankara Barosu Dergisi 97, 137; Konu hakkında detaylı bilgi için bkz. Pelin Işıntan, 'Anayasa Mahkemesinin 8.12.2011 Tarihli Kararı Işığında Türk Hukukunda Velayet Hakkı Kendisine Verilmiş Kadının Çocuğun Soyadını Seçme Hakkı Mevcut Mudur?' (2012) (1) Galatasaray Üniversitesi Hukuk Fakültesi Dergisi 265, 270.

41 Üstün menfaati olduğuna karar verdiği duruma ilişkin bkz. Yargıtay 2 HD, E 2017/1097 K 2018/12772, 12.11.2018, <https://www.lexpera.com.tr/> Erişim Tarihi 30.09.2021. Mahkemenin üstün menfaati bulunmadığı için bu talebi reddettiği karar için bkz. Yargıtay 2. HD, E 2020/2199 K 2020/3166, 22.6.2020, <https://www.lexpera.com.tr/> Erişim Tarihi 30.09.2021.

42 Yabancı hukuklarda evil kadının ve çocuğun soyadı hakkında datyalı bilgi için bkz. Yıldız Abik, Kadının Soyadı ve Buna Bağlı Olarak Çocuğun Soyadı (Seçkin 2005) 144 vd. 
çocuğu doğurmaktır. Bunun bir sonucu olarak da, bir erkek aynı genetik yapıya sahip olmadığı için çocuk ile arasındaki soybağını reddetme hakkına sahip iken, örneğin taşıyıcı anne olduğu için doğurduğu çocuk ile aynı genetik mirasa sahip olmayan bir kadının soybağını reddetmesine Türk hukuk sistemi müsaade etmemektedir ${ }^{43}$. Görülüyor ki kadın ve erkek ile çocuk arasında soybağının kurulması açısından da soybağının reddi açısından da farklı prensipler kabul edilmiştir. Ancak ifade etmekte fayda vardır ki söz konusu düzenleme İsviçre Medeni Kanunu’nun 252. maddesinde de aynen benimsenmiştir.

\section{d. Bekleme Süresi Bakımından Değerlendirme}

Kadın erkek açısından farklı uygulamaya yer veren diğer bir hüküm ise Türk Medeni Kanunu’nun “2. Kadın için bekleme süresi” kenar başlıklı 132. maddesinde yer almaktadır. Buna göre evlenmiş ve boşanmış kadınlar evlenmiş ve boşanmış erkeklerden farklı olarak evliliğin sona ermesinden itibaren üç yüz gün geçmedikçe evlenemez. Evlenebilmeleri için ya kadının önceki evliliğinden hamile olmadığının anlaşılması ya da boşandıktan sonra ve bir daha evlenmeden evvel doğum yapmış olması gerekmektedir. Öncelikle belirtmekte fayda vardır ki söz konusu düzenleme İsviçre’den alınmış olmakla birlikte daha Türk Medeni Kanunu kabul edilmeden 2 yıl önce, 1.1.2000 tarihinde İsviçre de yürürlükten kalkmıştır. Nitekim günümüz teknolojisinde babalığın tespiti ve kadının hamile olup olmadığı bu kadar kolay tespit edilebilirken eşitliğe aykırı böyle bir hükmün halen mevcut olması da son derece anlamsizdir.

\section{YARGI KARARLARINDA}

Medeni Hukuka ilişkin değerlendirmenin başında miras hukuku alanında Yargıtay'ın kararına yer verilmiş ve mahkemelerin mirasbırakanın kadın ve erkek evlat arasında yaratmaya çalıştığı ayırımcılığı önlemek adına gösterdiği çaba gözler önüne serilmiştir. Ancak Yargıtay’n bu alandaki hassasiyetine her zaman rastlamak mümkün olmamaktadır. Gerek Yargıtay kararlarında gerekse Anayasa Mahkemesinin özel hukuk normlarının Anayasa’ya uygunluğuna ilişkin yaptığı denetiminde eşitlikçi bakış açısından ziyade kadının korunmaya muhtaç ve bağımlı bir birey olmasına dayanan gerekçelere rastlanmaktadır. Bu bağlamda mahkemelerin çoğunlukla aile birliği ve kökleşmiş gelenekleri korumaya yönelik bir tutum sergilediği ve bu nedenle de kadın erkek eşitliğini değil toplumsal cinsiyet kalıplarını pekiştiren bir yaklaşım içerisinde olduğu görülmektedir ${ }^{44}$. Yargıtay’n özellikle aile birliğindeki yükümlülükler konusunda, “Türk Aile yapısı” adı altında yine eşitliğe aykırı birçok karara rastlanmaktadır. Örneğin Yargıtay daha yeni tarihli sayılabilecek bir kararında erkeğin fiziksel ve psikolojik şiddet uygulaması karşısında kadının güven sarsıcı davranışları olması ile ev

43 Tülay Aydın Ünver ve Şeyda Dursun Karaahmetoğlu, 'Ana ile Çocuk Arasında Kurulan Soybağının Reddi' iç Zeynep Özlem Üskül Engin (ed), Toplumsal Cinsiyet ve Hukuk (I) (On İki Levha 2019) 302; Rona Serozan, Çocuk Hukuku, (2. Baskı, Vedat 2005) III \$5 29-30; Şükran Şıpka: 'Taşıyıcı Annelik ve Getirdiği Hukuki Sorunlar', <https://www. turkhukuksitesi.com/makale_537.htm> Erişim Tarihi 24.12.2018.

44 Ayşe Seda Gülseven, 'Türk Aile Hukukunda Toplumsal Cinsiyet Rolleri’ (2017) (132) Türkiye Barolar Birliği Dergisi 183, 197. 
işleri ve ortak çocuklar ile ilgilenmemesini eşit kusur saymıştır ki kararda güven sarsıcı davranışların ne olduğu da açıllanmamıştır ${ }^{45}$.

Yukarıda detaylı olarak ele alınan Anayasa Mahkemesi kararları da göz önünde bulundurulduğunda Anayasa mahkemesinin geçmişe nazaran daha eşitlikçi bir bakış açısıyla değerlendirme yapmaya başladığı görülmekle birlikte kamu düzenini koruma adı altında bazı konularda direndiği anlaşılmaktadır. Özellikle soyadı ve soybağı gibi soyun devamı konularda ataerkil bakış açısından tam anlamıyla sıyrilabildiğini söylemek oldukça güçtür.

\section{B. CEZA HUKUKU (CEZA GENEL HUKUKU, CEZA ÖZEL HUKUKU, CEZA MUHAKEMESI HUKUKU, INFAZ HUKUKU)}

\section{GENEL OLARAK}

İnsan Hakları Evrensel Bildirgesi ${ }^{46}$ 1. maddesinde; "Bütün insanlar özgür, onur ve haklar bakımından eşit doğarlar. Akıl ve vicdana sahiptirler, birbirlerine karşı kardeşlik anlayıșıyla davranmalıdırlar." hükmünü getirirken 2. maddesi ile de; "Herkes, ırk, renk, cinsiyet, dil, din, siyasal veya başka bir görüş, ulusal veya sosyal köken, mülkiyet, doğuş veya herhangi başka bir ayrrm gözetmeksizin bu Bildirge ile ilan olunan bütün haklardan ve bütün özgürlüklerden yararlanabilir." düzenlemesini yapar. Ardından 7. madde ile; "Herkes yasa önünde eşittir ve ayrım gözetilmeksizin yasanın korunmasindan eşit olarak yararlanma hakkina sahiptir" der.

Avrupa İnsan Hakları Sözleşmesi ${ }^{47}$ ise; İnsan haklarına saygı yükümlülï̈̆̆̈i başlı̆̆ı altında "Yüksek Sözleşmeci Taraflar kendi yetki alanları içinde bulunan herkesin, bu Sözleşme’nin birinci bölümünde açıklanan hak ve özgürlüklerden yararlanmalarını sağlarlar." düzenlemesinin ardından 14. madde ile Ayırımcılık yasağı başlığı altında; “Bu Sözleșme’de tanınan hak ve özgürlüklerden yararlanma, cinsiyet, ırk, renk, dil, din, siyasal veya diğer kanaatler, ulusal veya toplumsal köken, ulusal bir azınlı̆̆a aidiyet, servet, doğum başta olmak üzere herhangi başka bir duruma dayah hiçbir ayrımcillk gözetilmeksizin sağlanmalıdır." diyerek açıkça ayırımcılık yasağını düzenler.

Türk Hukuku bakımından üst norm olan Anayasa 10. maddesi ${ }^{48}$ ile Kanun önünde eşitlik başlı̆̆ altında; "Herkes, dil, ırk, renk, cinsiyet, siyasi düşünce, felsefi inanç, din, mezhep ve benzeri sebeplerle ayırım gözetilmeksizin kanun önünde eșittir./ Kadınlar ve erkekler eşit haklara sahiptir. Devlet, bu eşitliğin yaşama geçmesini sağlamakla yükümlüdür. Bu maksatla alnacak tedbirler eşitlik ilkesine aykurı olarak yorumlanamaz./ Çocuklar, yaşllar, özürlüler, harp ve vazife şehitlerinin dul ve yetimleri ile malul ve gaziler için alınacak tedbirler eşitlik ilkesine aykırı sayılmaz./ Hiçbir kişiye, aileye, zümreye veya sinıfa

45 Yargitay 2 HD, E 2021/1736 K 2021/2890, 12.04.2021, Yargitay Bilgi Bankası <https://karararama.yargitay.gov.tr/ YargitayBilgiBankasiIstemciWeb/>, Erişim Tarihi 30.09.2021. Aynı yönde Yargıtay 2 HD, E 2016/15692 K 2018/6093, 03.05.2018, <https://www.lexpera.com.tr/> Erişim Tarihi 30.09.2021.

46 <http://www.multeci.org.tr/wp-content/uploads/2016/12/Insan-Haklari-Beyannamesi-1.pdf $>$ Erişim Tarihi 04.05.2021.

47 <https://www.echr.coe.int/Documents/Convention_TUR.pdf > Erişim Tarihi 04.05.2021.

$48<$ https://www.mevzuat.gov.tr/mevzuat> Erişim Tarihi 04.05.2021. 
imtiyaz tanınamaz./ Devlet organları ve idare makamları bütün işlemlerinde kanun önünde eşitlik ilkesine uygun olarak hareket etmek zorundadırlar." düzenlemesini getirir ve ardından 11. maddede; Anayasanın bağlayıcılı̆̆ı ve üstünlï̆̆̈̈ başlığı altında; "Anayasa hükümleri, yasama, yürütme ve yargı organlarını, idare makamlarını ve diğer kuruluş ve kişileri bağlayan temel hukuk kurallarıdır./ Kanunlar Anayasaya aykırı olamaz." diyerek Devletin tüm organ, kurum ve kurulları ile Anayasa kurallarına bağlı olduğunu ve yürürlüğe girecek mevzuatın da Anayasa’ya aykırı olamayacağını açıcça belirler. Ayrıca 90. maddesinde Milletlerarası andlaşmaları uygun bulma başlığı altında, "Usulüne göre yürürlüğe konulmuş Milletlerarası andlaşmalar kanun hükmündedir. Bunlar hakkında Anayasaya aykırılık iddiası ile Anayasa Mahkemesine başvurulamaz. Usulüne göre yürürlüğe konulmuş temel hak ve özgürlüklere ilişkin milletlerarası andlaşmalarla kanunların aynı konuda farklı hükümler içermesi nedeniyle çıkabilecek uyuşmazlıklarda milletlerarası andlaşma hükümleri esas alınır.” açık hükmü ile taraf olduğumuz Sözleşmeler bakımından da Sözleşmelerin üstünlügünü ve özellikle iç hukuk ile uluslararası hukuk çatışmasında evrensel hukuk değerlerini koruma amacı güden ve bu nitelikte hüküm içeren antlaşmaların esas alınması zorunluluğunu kabul ederek, üstün ve uygulanacak normu insan hakları lehine belirlemiş ve tavrını netleştirmiştir.

Bugün genel olarak belirttiğimiz üst normlar bazında eşitlik ilkesinin esas alınması ve ayırımcılık fiillerinin her türünün hayatın her alanından çıkartılması zorunluluğu, konunun tüm taraflar özelinde bağlayıcılığg ve bu hususta istisna kabulünün mümkün olmadığ

Ceza mevzuatı bakımından derinlemesine irdeleme bu çalışmanın sınırlarını aşacak niteliktedir. Bu nedenle belirtmeliyiz ki, çalışmamızda dikkat çeken bazı temel hususların gündeme getirilmesi ve verilen örneklerle konu üzerinde düşünmeyi sağlamak amaçlanmıştır.

\section{TÜRK CEZA KANUNU BAKIMINDAN GENEL DEĞERLENDIRME}

\section{7 sayılı Türk Ceza Kanunu ${ }^{49}$ Adalet ve kanun önünde eşitlik ilkesi başlığını taşıyan}

3.maddesinin ikinci fikrasında; "(2)Ceza Kanununun uygulamasında kişiler arasında ırk, dil, din, mezhep, milliyet, renk, cinsiyet, siyasal veya diğer fikir yahut düşünceleri, felsefi inanç, milli veya sosyal köken, doğum, ekonomik ve diğer toplumsal konumları yönünden ayrım yapılamaz ve hiçbir kimseye ayrıcalık tanınamaz." hükmü yer almaktadır. 765 sayılı mülga Türk Ceza Kanunu’nda bulunmayan ve gerekliliği tartışmalı olsa da ${ }^{50}$ var olması konunun hassasiyetine binaen kabul edilebilir olan bu hüküm Ceza Kanunu uygulamasında herkese eşit davranılması gerektiğini ve hiçbir kimseye, hiçbir gerekçe ile ayırımcılık yapılamayacağını ifade eder. Ceza Kanunu'nun 122. maddesi ise Nefret ve ayırımcılık suçu başlı̆̆1 altında; "(1)Dil, ırk, milliyet, renk, cinsiyet, engellilik, siyasi düşünce, felsefi inanç, din veya mezhep farklılı̆̆ından kaynaklanan nefret nedeniyle; a)Bir kişiye kamuya arz edilmiş olan bir taşınır veya taşınmaz malın satılmasını, devrini veya kiraya verilmesini,/ b)Bir kişinin kamuya arz edilmiş belli bir hizmetten yararlanmasını,/ c)Bir kişinin işe alınmasını,/ d)Bir kişinin olağan bir ekonomik etkinlikte bulunmasını, / engelleyen kimse, bir yıldan üç yıla kadar hapis cezası ile cezalandırılır." hükmünü getirmiştir ki, benzer bir düzenleme mülga Ceza Kanunu’nda bulunmamaktadır. Önemli

49 Nur Centel, Hamide Zafer ve Özlem Çakmut, Karşılaştırmalı ve Tablolu Türk Ceza Kanunu ve İlgili Mevzuat, (18.Bası, Beta 2020) 8, 84 .

50 Konuya ilişkin ayrıntılı bilgi için bkz. Nur Centel, Hamide Zafer ve Özlem Çakmut, Türk Ceza Hukukuna Giriş, (11.Bası, Beta 2020) 5 . 
bir adım olmakla birlikte yeri gelmişken hemen ifade edilmelidir ki, TCK m.122 düzenlemesi gerçek anlamda nefret ve ayırımclık suçlarını kapsayan ve yaptırıma tabi kılan bir yapıyı haiz değildir ${ }^{51}$.

Ceza Hukuk normlarının ataerkil bir bakış açısıyla düzenlendiği, bu bakışın önyargılardan temelini aldığı ve süreklilik arz ettiği ve bu nedenle de eşitlik temelli olmaktan uzak olduğu, dolayısıyla "adaletsiz" bulunduğu ifade edilmektedir ${ }^{52}$. Bu çıkarımın özellikle 765 sayılı mülga Türk Ceza Kanunu düzenlemesini ele aldığımızda yadsınamaz bir gerçeklik olduğu ortadadır.

Öncelikle 5237 sayılı Türk Ceza Kanunu kişilere karşı suçları genel hükümlerden hemen sonra düzenleyerek insana önem verdiği bir, devlete karşı işlenecek suçlar yerine insana karşı işlenecek suçların daha önemli olması nedeniyle öncelik gerçekleştirildiği ve kanun yapıcının bu konuya gösterdiği hassasiyetin, metnin oluşum felsefesinden kaynaklandığı ifade edilmiştir.

5237 sayılı Türk Ceza Kanunu ile birlikte özellikle kanun yazım usulüne genel olarak baktığımızda kullanılan terim ve kavramlarda -yetersiz de olsa - ciddi değişiklikler yapıldığını ve özellikle eşitlik, ayırımcılık bağlamında sorunlu düzenlemelerin kanun kapsamından çıkarıldığını görüyoruz. $\mathrm{Bu}$ kapsamda; mülga 765 sayılı Türk Ceza Kanunu’nun dokuzuncu babının birinci faslının "adam öldürmek cürümleri” başlı̆̆ ${ }^{53}$ ile maddelerde geçen "adam öldürme" ifadeleri, 5237 sayılı Türk Ceza Kanunu’nda değiştirilmiş, yerine madde metninde "insan" ifadesi kullanılmış ve Kanun’un ikinci kısmının başlığı da "kişilere karşı suçlar" olarak düzenlenmiştir. Bu husus metnin bütününe yansımış ve düzenlemelerde, insan, kişi, kişiler, herkes, bir kimse gibi genel ifadeler kullanılmıştır.

Mülga Kanun madde düzenlemeleri içinde geçen ${ }^{54}$, "üvey evlat, evlatlık, karı, koca, babalık, analık, kız - kadın, evli kadın, kızlık bozma, kadın oynatma, ırz, iffet, şerefi kurtarmak saiki” vb. kelimeler 5237 sayılı Türk Ceza Kanunu’nda temelde yer bulmamıştır; daha doğru bir ifade ile ayırıcı bir dil ile yazılan kavram ve metinler -eleştirilecek yanları bulunmakla birlikte- toplumsal değişim, eşitlik, toplumsal eşitlik ve çağın gerekleri doğrultusunda ya hiç alınmamış ya da eşitlik temelli kavramlara dönüştürülerek kendilerine yer bulabilmişlerdir. Örnek vermek gerekirse yeni kullanılan kavramlar: Eş, çocuk (üvey, öz, evlatlık ayırmaksızın), alt-üst soy, cinsel saldırı, cinsel dokunulmazlık, insan (kız-kadın-erkek ayırmaksızın) gibidir. Nitekim 5237 sayılı Türk Ceza Kanunu’nda ırza geçme suçu söz konusu olduğunda fail ve mağdurun evlenmesinin erteleme ve düşme nedeni kabul edilmesine ilişkin hüküm yer almamıştır. Ayrıca evli ve bekar kadın, bakire olan ve olmayan kadın ayrımlarına yer verilmemiștii ${ }^{55}$.

51 Bu konuda ayrıntılı bilgi için bkz. Özlem Y. Çakmut ve Anıl Akyıldız, "Sporda Ayrımcılık ve Türk Ceza Hukuku” (2021), III (2), İstanbul Spor Hukuku Dergisi, 3, 8 vd.; Ulaş Karan, “Türk Hukukunda Ayrımcılık Yasağı ve Türk Ceza Kanunu’nun 122.Maddesinin Uygulanabilirliği” (2007), 20 (73), Türkiye Barolar Birliği Dergisi, 146, 170 vd.

52 Gülriz Uygur, “Toplumsal Cinsiyet ve Adalet: Hukuk Adaletsizdir”, (2015), 4, Ankara Barosu Dergisi, 121, 122, <https:// acikders.ankara.edu.tr/pluginfile.php/33627/mod_resource/content/0/Toplumsal\%20Cinsiyet\%20ve\%20Hukuk.pdf > Erişim Tarihi 04.05.2021.

53 Nur Centel, Hamide Zafer ve Özlem Çakmut, Türk Ceza Kanunu, Ceza Muhakemeleri Usulü Kanun ve Yeni Türk Ceza Kanunu, (4.Bas1, Beta 2004), 245.

54 Bu konuda ayrıntılı bilgi için bkz. Mihriban Toluay, İnsan Hakları Hukukunda Cinsiyet Temelinde Ayrımcılık Yasağı, (1.Bası Onikilevha 2021), 73 vd.

55 Nur Centel, "Yeni Türk Ceza Yasası Ve Kadın”, 1, 7, <http://nurcentel.com/makaleler/yenitckvekadin.pdf > Erişim Tarihi 04.05.2021. 
Suçların düzenlenmesinde özellikle kırılgan kesimlerin haklarının ve hukuki menfaatlerinin korunması bakımından hassas olunma gayreti -bazı yönlerden eksik kalsa da- metne yansımış görünmektedir: Bu kapsamda; bazı suçların düzenlendiği kısımların başlığı değiştirilmiş (Cebren Irza Geçen, Küçükleri Baştan Çıkaran ve İffete Taarruz Edenler yerine Cinsel Dokunulmazlığa ${ }^{56}$ Karşı Suçlar başlığı; Kız ve Kadın ve Erkek Kaçırmak başlı̆̆ı yerine Hürriyete Karşı Suçlar/Kişiyi Hürriyetinden Yoksun Kılma başlı̆̆ı kullanılmıştır.). Yine bazı fiiller suç kapsamına alınmış (kısmen ensest fiilleri, töre saikiyle insan öldürme gibi), bazı suç teşkil eden fiiller bakımından ayırımcı uygulamaları doğuran düzenlemeler, ki bir kısmı süreçte mülga Kanun yürürlükte iken Anayasa Mahkemesi'nin iptal kararları ile yürürlükten kaldırılmış (kadın ve erkeğin zina fiillerini suç sayan düzenlemenin eşitlik ilkesine aykırı bulunarak iptal edilmesinde olduğu gibi), diğer bir kısmı ise yasama organının tasarrufu ile kaldırılmış (fuhuş ile meşgul olan kadınlara karşı işlenen cinsel saldırı suçlarında indirim yapılmasının öngörüldügü düzenleme, zina halinde yakalanana karşı işlenen öldürme veya yaralama fiillerinde indirim yapılmasının öngörüldügü madde gibi), bir kısmı da yeni Kanun'un yapımı sürecinde alınmayarak suç olmaktan çıkartılmıştır (evlenmek vaadi ile kızlık bozma suçu, şeref saiki ile yeni doğan çocuğun öldürülmesi suçu gibi). Öte yandan özellikle cinsel saldırı suçunda eşe karşı işlenen cinsel saldırı fiili, diğer bir ifade ile evlilik içi cinsel saldırı fiili suç kapsamı içine alınmıştır. Eş olan kadına karşı klasik bakış açısından uzaklaşılması adına önemli bir adım olsa da bu suçun unsurları bakımından basit cinsel saldırı fiilinden farklı olması ve soruşturma ve kovuşturmasının şikayete tabi tutulması gerçek anlamda fiil ile korunmak istenen hukuki menfaat ihlalinin önlemekten uzak tutmakta ve suç normu ile beklenen amaca hizmet etmeyi mümkün kılmamaktadır ${ }^{57}$. 5237 sayılı Türk Ceza Kanunu m.104'de yer alan reşit olmayanla cinsel ilişki suçu bakımından klasik anlayışı temsil eden cinsel ilişki kavramının kullanılması ve doğal sonucu olarak failin erkek olması zorunluluğunun kabulü sorunlu bir düzenleme olarak karşımıza çıkmaktadır.

Mülga Türk Ceza Kanunu’nda özellikle cinsel özgürlüğe yönelik suçlar incelendiğinde korunan hukuki menfaatin kadının salt cinsel özgürlüğü, dokunulmazlığı ve onurunun olmadığı, aile kurumu içinde ele alınan kadına önem atfedildiği, ailenin kutsallı̆̆ı nedeniyle o küçük topluluğun bireyi olan kadının korunduğu gerçeği ile karşı karşıya kalırız ${ }^{58}$.

5237 sayılı Türk Ceza Kanunu'nda öldürme fiilinin töre saiki ile işlenmesi suçun nitelikli hali olarak düzenlenmiş durumdadır. Ancak bu noktada önemle ifade edilmelidir ki, töre saiki yerine benimsenmesi gereken kavram "namus saiki” olmalıydı. Özellikle kadın-erkek eşitliği bakımından konuyu ele aldığımızda geleneksel ve ataerkil yapının normlara olan yansımasının yarattığı ayırımcı dilin ortadan kaldırılması insan öldürme suçlarında "namus saiki” kavramının benimsenmesi ve özellikle bu saikle işlenen suçlarda haksız tahrik indiriminin uygulanmasının önüne geçecek zorlayıcı şartların kabulü ile mümkün olabilecektir. Namus cinayetlerinin, öldürme suçu kapsamında nitelikli

56 Dokunulmazlık kavramının kullanılmasının hatalı olduğu konusunda bkz. Özlem Yenerer Çakmut, "Cinsel Suçlarda Hukuksal Boyut”, (2018), 4(1), 65, 66, Türkiye Klinikleri Adli Tip - Özel Konular, <https://www.turkiyeklinikleri.com/ article/tr-cinsel-suclarda-hukuksal-boyut-81435.html> Erişim Tarihi 04.05.2021.

57 Centel (no 55) 8.

58 Toluay (no 54) 74 . 
hal içine alınmamış olması önemli bir eksikliktir ${ }^{59}$. Haksız tahrik ve takdiri indirim nedenlerinin uygulama örnekleri bakımında özellikle kullanılan dil ve belirlenen gerekçeler dikkat çekici bir görünüm arz etmektedir. Bu noktada namus kavramı ile özdeşleşen ve ataerkil bir yapının yansıması olan ifadelerin gerekçede baskın olması ve indirim nedeni olarak yer alması toplumsal eşitlik temeline aykırı düşmekte ve bu saikle işlenen insan öldürme suçlarının mazeretini oluşturmaktadır. $\mathrm{Bu}$ nedenle kullanılan ifadeler, işlenen fiilleri haklı kılmamalı, tam tersine toplumsal huzura vurulan damganın bir nişanesi olarak kabulü mümkün görülmeyen eylemler olduklarını ifade eden ve tolerans gösterilmesi mümkün bulunmayan fiiller olarak cezalandırılmalıdır.

Ceza Hukukunun temel ilkesi olan kanunilik kapsamında yaptırımların kanun ile belirlenmesi zorunludur. Türk Ceza Kanunu'nda yaptırımlar hapis ve adli para cezası olarak belirlenmiştir. Kısa süreli hürriyeti bağlayıcı cezalar bakımından seçenek yaptırımlar bulunmakla birlikte uygulama alanı dar ve sınırlıdır. Yaptırım çeşitliliğinin olmaması bireyselleştirme bakımından kırılgan grupların özelliklerinin dikkate alınamamasını sonuçlamaktadır. Bu nedenle yaptırımların çeşidinin artırılması kırılgan gruplar bakımından daha anlamlı ve cezanın amacını sağlamak bakımından da daha işlevsel olacaktır. Cinsel saldırı ve çocuğun cinsel istismarı suçları bakımından zincirleme suç hükümlerinin uygulama dışı bırakılması bu yöndeki suçların işlenmesi bakımından caydırıcı bir etki sağlayacaktır kanaatindeyiz, bu yolla toplumsal eşitlik kurallarının cinsel suçlar bakımından işlevsel hale getirilmesi söz konusu olabilecektir.

\section{CEZA MUHAKEMESI HUKUKU NORMLARI BAKIMINDAN GENEL DEĞERLENDIRME}

Ceza muhakemesi hukukunda da toplumsal eşitsizlik örneklerine ilişkin birçok husus ile karşılaşmak mümkündür. Çalışmanın sınırları nedeniyle birkaç önemli ve dikkat çekici hususu vurgulamakla yetinmek durumundayı.

Ceza muhakemesi hukukunda önemli delil elde etme araçlarından biri beden muayenesidir. Beden muayenesi ile insan vücudu incelenmektedir. Tibbi müdahale teşkil eden bu muayene, mağdurun rızası ile gerçekleştirilmekle birlikte, suç söz konusu olduğunda, özellikle cinsel suçlar, mağdurun bedeninden elde edilecek delillerin önemi nedeniyle çoğunlukla kadınların veya çocukların defalarca bu muayeneye maruz bırakılması söz konusu olmakta ve her defasında yaşanan travma ile aynı acı tekrarlanmaktadır. Her ne kadar şartları açıkça düzenlenmiş bulunsa da müdahale niteliği itibarıyla, özellikle kırılgan gruplar üzerinde, önemli etkiler yaratmaktadır. Kadınların, koşullar elverdikçe kadın doktor tarafından muayene edileceğine ilişkin hüküm, eleştirilmekle birlikte, 5271 sayılı Ceza Muhakemesi Kanunu’nda yer almış bulunmaktadır.

Özellikle genital muayene Türkiye’de, beden muayenesine ilişkin ayrıntılı hükümler ve 5237 sayılı Türk Ceza Kanunu’nda kabul edilen genital muayene suçu (TCK m.287) öncesinde, kadınlar bakımından oldukça tartışmalı ve kabulü mümkün olmayan durumların yaşanmasına neden olmaktaydı. Okula giden veya yurtlarda kalan kız çocuklarının gerek aileleri veya gerekse okul/yurt müdürleri

59 Benzer yönde bkz. Toluay (no 54) 78 vd.; Centel (no 55) 12. 
tarafından bekaret kontrolü amacıyla, genital muayeneleri için doktor kontrolüne gönderilmeleri, tarifi imkansız travmalara neden olduğu gibi, insan onuru ile bağdaşmayan aşağılayıcı muameleye maruz kalma yasağına ve dolayısıyla toplumsal eşitlik ilke ve esaslarına aykırılık oluşturmaktaydı. Getirilen düzenlemeler ile çağ dışı bu uygulamanın devamı mümkün olmaktan çıkartılmış, ilgililer hakkında yaptırım öngörülen suç fiilleri haline getirilmiştir ${ }^{60}$.

Öte yandan adalete erişim bakımından yasal olmasa da uygulamada kadınlar adına ortaya çıkan eşitsizlik toplumsal eşitlik idesinin gerçekleşmesini engellemektedir ${ }^{61}$.

\section{INFAZ HUKUKU NORMLARI BAKIMINDAN GENEL DEĞERLENDIRME}

5275 sayılı Ceza ve Güvenlik Tedbirlerinin İnfazı Hakkında Kanun'un İnfazda temel ilke başlı̆̆ ile düzenlediği 2.maddesine göre; “(1)Ceza ve güvenlik tedbirlerinin infazına ilişkin kurallar hükümlülerin ırk, dil, din, mezhep, milliyet, renk, cinsiyet, doğum, felsefî inanç, millî veya sosyal köken ve siyasî veya diğer fikir yahut düşünceleri ile ekonomik güçleri ve diğer toplumsal konumları yönünden ayırım yapılmaksızın ve hiçbir kimseye ayrıcalık tanınmaksızın uygulanır./ (2)Ceza ve güvenlik tedbirlerinin infazında zalimane, insanlık dışı, aşağılayıcı ve onur kırıcı davranışlarda bulunulamaz.”.

İnfaz Kanunu getirdiği normlarda tutuklu ve hükümlüler için hiçbir gerekçe ile ayırımcılık yapılmayacağını hükme bağlamış ve uygulamanın pozitif ayırımcılık dışında (kadınlar için ayrı ceza evleri inşası, kimi hükümlülerin özel durumları nedeniyle bireyselleştirme araçlarından faydalanılarak farklı infaz koşullarına tabi tutulmaları gibi esaslar) negatif ayırımcılık uygulamalarının yapılmaması esasını benimsemiştir.

Bu kapsamda İnfaz Hukukunda kırılgan gruplar için (kadın, çocuklu kadın, yaşlılar (65/70/75 yaşındaki mahkumlar), engelliler için belli bir ağırlığa kadar olan cezalarının çektirilmesi bakımından diğer mahkumlara göre daha lehe olan özel infaz usulleri benimsenmiştir. Örneğin, geceleri infaz, hafta sonları infaz, infazın ertelenmesi, seçenek yaptırımlardan faydalanma, çocuklar için benimsenen infaz uygulamaları vb. Çocuklar ve belli bir yaş üzerindeki mahkumlar için cezanın ertelenmesi kurumu bakımından daha lehe hükümler benimsenmiştir.

Öte yandan yine de gözden geçirilmesi gereken ve daha hassas düzenlemelere ihtiyaç duyan durumlar yok değildir. Kısaca birkaç tanesine vurgu yapmak gerekirse: İnfaz kurumlarında kadın mahkumların özel günlerine ilişkin hijyenik ped gibi ihtiyaçlarının devlet tarafından ücretsiz karşılanmaması önemli bir eksikliktir. Çocukların belli bir yaşa kadar anne ile birlikte kalmasına olanak sağlanması önemli olmakla birlikte, diğer mahkumlarla birlikte aynı ortamda kalıyor olmaları çocuk gelişimi

60 Özlem Y. Çakmut, "Yargı Kararları Işı̆ğında Genital Muayene Suçu (TCK m.287)", iç Yener Ünver ve İ.Hamit Hancı (edr), V. Uluslararası Sağlık Hukuku Kongresi, Özyeğin Üniversitesi Hukuk Fakültesi, Adli Bilimciler Derneği, Balıkesir Barosu, (Seçkin 2020), 125, 126.

61 Konuya ilişkin ayrıntılı bilgi için bkz. Duygu Hatipoğlu Aydın, "Kadınların Adalete Erişimi”, (2015), 4, ABD, 77, 80 vd., $<$ https://dergipark.org.tr/en/download/article-file/398470 > Erişim Tarihi 09.05.2021; Mary Jane Mossman, "Shoulder To Shoulder": Gender And Access To Justice", 350, $351 \mathrm{vd}$. <https://digitalcommons.osgoode.yorku.ca/cgi/viewcontent. cgi? article $=2545 \&$ context=scholarly_works $>$ Erişim Tarihi 09.05.2021. 
açısından sorunludur. Yine cinsel yönelimi farklı olan bireyler bakımından ayrı cezaevi modelinin benimsenmemesi sıkıntıların yaşanmasına neden olmaktadır. Ayrıca farklı beslenme alışkanlıkları olanlar bakımından (vejeteryan, vegan vb.) ayrı bir uygulama yapılmaması sorun yaratmaktadır.

\section{YARGI KARARLARINDA}

Yargı kararlarına ilişkin açıklama öncesinde önemle ifade edilmelidir ki, yargı mensubu olan hakim ve savcılar bakımından, kadın ve erkeklerin sayısal karşılaştırması yapıldığında erkek yargı mensuplarının sayılarının, kadınlara göre oldukça fazla olduğu görülmektedir ${ }^{62}$. Benzer durum avukat sayılarına da yansımışıır ${ }^{63}$. Zaman içinde artışlar olsa da oransal olarak belirgin bir değişiklik görülmemektedir. Biraz daha iyi olmakla birlikte maalesef benzer durum Hukuk Fakülteleri akademik kadrosu özelinde de görülmektedir ${ }^{64}$. Özellikle kamu otoritesine bağlı çalışılan meslekler bakımından bu farkın aynı biçimde şekillendiğini ifade etmek yanlış olmayacaktır. İște bu durum, yargı kararlarına da ataerkil bir bakış açısının yansımasını, getirmekte; değişim istenildiği hızda gerçekleşememektedir.

\section{a. Anayasa Mahkemesi Kararları Bakımından}

Anayasa Mahkemesi hukuk devleti ilkesinin esaslarından biri olarak gördüğü eşitlik ilkesini, önüne gelen davalar bakımından ele almış ve irdelemiştir ${ }^{65}$. Mahkemèye göre; “...yasaların uygulanmasında dil, ırk, renk, cinsiyet, siyasî düşünce, felsefî inanç, din ve mezhep ayriliğ gözetilmeyecek ve bu nedenlerle eşitsizliğe yol açılmayacaktır. Bu ilkeyle, birbirleriyle ayn durumda olanlara ayrı kuralların uygulanması ve ayrıcalkk kişi ve toplulukların yaratılması engellenmektedir. Yasa önünde eşitlik, herkesin her yönden ayn kurallara bağh olacağı anlamına gelmez. Kimilerinin Anayasa'nın 13. maddesinde öngörülen nedenlerle değişik kurallara bağh tutulmaları eșitlik ilkesine aykırılık oluşturmaz. Durum ve konumlarındaki özellikler, kimi kişiler ya da topluluklar için değişik kuralları ve değģşik uygulamaları gerektirebilir. Aynı hukuksal durumlar aynı, ayrı hukuksal durumlar ayrı kurallara bağl tutulursa Anayasa'da öngörülen eşitlik ilkesi zedelenmez." (AYMK, 24.11.1999-1999-27/ 1999-42 sayllı karar). Benzer kararları olan Anayasa Mahkemesi, haklı neden ölçütünü kullanarak, kanun önünde eşitlik ilke ve esası bakımından, yasayla getirilmiş ve farklılığı haklı kılan bir nedene dayanıldığı durumda, diğer bir ifade ile haklı nedenin varlığı kanaatine varıldığında, düzenlemenin Anayasảya aykırı olmadığı

62 Erkek hakim ve savcıların sayısı 11158; kadın hakim ve savcı sayısı ise 4146'dır. <https://www.hsk.gov.tr/Eklentiler/ Dosyalar/39c8a8cb-7600-4159-933b-48881447f0d4.pdf> Erişim Tarihi 04.05.2021.

63 31.12.2019 itibarıla kadın avukat sayıs1 50184; erkek avukat sayısı ise 70507'dir. Bkz. <https://www.barobirlik.org.tr/ Haberler/2019-avukat-sayilari-31122.019.81078 > Erişim Tarihi 04.05.2021.

64 Her geçen gün sayıları artıyor olsa da 93 Hukuk Fakültesi’nin bulunduğu dönemde yapılan bir araştırmada erkek akademisyen sayısı 1836 iken kadın akademisyen sayısı 1609 olarak belirlenmiştir. Bkz. <https://www.researchgate.net/ publication/342511353_Turkiye'de_Akademide_Cinsiyet_Esitsizligi_Raporu_2020_Gender_Inequality_Report_at_ the_Academy_in_Turkey_2020 > Erişim Tarihi 04.05.2021.

65 Konuya ilişkin detaylı bilgi için bkz. Jülide Gül Erdem, "Yargı Kararlarında Kanun Önünde Eşitllik İlkesi Ve Kadın Erkek Eşitliği”, (2017), 4 (8), Akademik Hassasiyetler, 19, 28, <https://dergipark.org.tr/tr/download/article-file/394590 > Erişim Tarihi 04.05.2021. 
sonucuna varmaktadır ${ }^{66}$. Anayasa Mahkemesi kararlarında kullandığg haklı neden kavramına verdiği anlamı şu şekilde açıklamaktadır: “... Anayasa Mahkemesinin kararlarının anlam ve öneminin tüm ağırlı̆̆ını taşıyan "haklı neden” ve "kamu yararı" kavramlarına, öğretide, eşitliği bozduğu ileri sürülen sınıflandırma ya da ayrımın, a) ANLAŞILABİLIR, b) AMAÇLA İLGİLI, c) MÂKUL VE ÂDİL olması ölçütleriyle hakuksal biçim ve içerik kazandırılmaktadır. Getirilen düzenleme herhangi bir biçimde, birbirini tamamlayan, birbirini doğrulayan ve birbirini güçlendiren bu üç ölçütten birine uymuyorsa, eşitlik ilkesine aykırı bir yön vardır, denebilir. Çünkü, eşitliği bozduğu ileri sürülen kural, haklı bir nedene dayanmamakta ya da kamu yararı amacıyla yürürlüğe konulmamış olmaktadır. Başlangiçta varolan uyum içindeki bu koşullar, zamanla aralarındaki bağın çözülmesi halinde de Anayasa kurallarına aykırı hale gelebilirler.", (AYMK, 24.11.1999-1999-27/ 1999-42 sayılı karar) ${ }^{67}$.

Anayasa Mahkemesi kararlarından kadın-erkek eşitliğine de değinmiştir ${ }^{68}$. Bu konudaki Yüksek Mahkeme görüşünün zaman içinde olumlu ve çağı yakalar biçimde değiştiğini de ifade etmek yanlış olmayacaktır. Nitekim Anayasa Mahkemesi’nin -kabul etmemiz ve katılmamız mümkün olmayan, ancak bir anlayışı temsil etmesi bakımından önemli bulduğumuz kadın-erkek eşitliği ötesinde kadınlar arasında iffetli olma/olmama kriterine değinerek 765 sayılı mülga Türk Ceza Kanunu m.438'in Anayasa’ya aykırılı̆̆ı konusunda verdiği bir kararında; “... fuhşu kendine meslek edinen bir kadını zorla kaçıran veya ırzına geçen bir kişiye verilecek cezanın, aynı eylemleri iffetli bir kadına karşı gerçekleştiren kişiye verilecek cezadan daha az olmasının hakl bir nedene bağlı bulunup bulunmadığının saptanması zorunludur. Devlet, toplumsal barışı, kamu düzenini, bireylerin güven ve huzurunu sağlamakla yükümlüdür. Kimi durumlarda Devlet, bu yükümlülüğ̈̈nü alacağı ceza önlemleri ile yerine getirmeye çalışır. Yasakoyucu, bu konuda bir düzenleme yaparken kişi yararı kadar kamu yararını da gözönünde bulundurmak zorunda olduğundan, kimi suçların niteliğini, işlenme biçimini, toplum için verdiği zararı da gözeterek değişik cezalar verilmesini öngörebilir. Cezanın belirlenmesinde suçtan zarar görenin kişiliği ve ona verilen zararın azlĭ̆ı veya çokluğu da etkilidir. Yasakoyucu değişik eylemler için değişik cezalar yanında daha hafif bir eylem için daha ă̆ır bir cezayı da uygun görebilir. Irza geçmek ve kaçırmak suçlarının fuhşu kendine meslek edinen bir kadına karşı işlenmesinde, bu kişinin uğradığı zarar ile aynı eylemlerin iffetli bir kadına karşı yapılması durumunda onun gördüğ̈̈ zarar eşit sayılamaz, iffetli bir kadının zorla kaçırılması veya ırzına geçilmesi onun onurunu, toplumdaki ve yaşadığı ortamdaki saygınlı̆̆ını, giderilmesi olanaksız ölçüde kıracaktır. Oysa, aynı eylemlerle karşılaşan fuhşu meslek edinmiş bir kadının bu ölçüde zarar gördü̈̆̈̈nü ileri sürmek ve kabul etmek güçtür. Fahişe, fuhşu kendisine meslek edinmiş, onu ticarî bir iş kabul etmiş olduğundan bu tür kadınların kişi ve cinsel özgürlükleri iffetli kadınlarınki kadar bozulmuş sayılamaz. Kaçırmak ve ırza geçmek eylemleri iffete karşı işlenen birer suç olması ve bu eylemlerle karşılaşan fuhşu meslek edinen birkadının uğrayacă̆ı zararın, iffetli bir kadının uğrayacă̆ı zarara göre çok daha az olacă̆ı gerçeğinden hareket eden Yasakoyucu bu nedenle Türk Ceza Yasasinın 438. maddesi ile böyle bir ayırıma yer vermiştir. Şu halde, fuhşu kendisine meslek edinen kadınlara karşı işlenen zorla

66 Erdem (no 65) 28.

67 Anayasa Mahkemesi kararı için bkz. <https://normkararlarbilgibankasi.anayasa.gov.tr/ ND/1991/40?KararNo=1991\%2F40 > Erişim Tarihi 04.05.2021.

68 Konuya ilişkin detaylı bilgi için bkz. Erdem (no 65) 35. 
kaçırmak veya ırza geçmek suçlarında böyle bir kadının uğradığı zararın aynı eylemlerle karşılaşan iffetli bir kadının uğradığı zarara göre daha az olması bu ayırımın haklı nedenini oluşturmaktadır. Bu bakımdan eşitlik ilkesine aykırı olduğu iddia edilen itiraz konusu Türk Ceza Kanunu'nun 438. maddesi, bu eylemlerle karşılaşan kadınların değiş̧ik durumlarından kaynaklanan zorunluluklara ve dolayısılla haklı nedenlere dayandığından Anayasa’nın 10. maddesinde açıklanan eşitlik ilkesine aykırı değildir.", biçiminde hüküm kurmuştur (AYMK, 29.11.1990-1990-30/1990-31 sayılı karar) ${ }^{69}$.

Konuya ilişkin verdiği bir başka kararında; "Anayasa Mahkemesi 10.3.1964 günlü Resmi Gazete'de yayımlanmış olan 25.10.1963 günlü Esas: 1963/ 148 Karar: 1963/256 sayıl kararında: "Cinsiyet yasa önünde eşitliği engelleyen bir neden değildir" açıklamasılla, kadın erkek eşitliğini belirgin duruma getirmiş̧tir. Kadın erkek eşitliği, kadının erkekle eşit konuma getirilmesi olarak yorumlanmalıdır. Bunun aksi, yani erkeğin, daha kısıtl haklan olan kadınla eşit duruma getirilmesi eşitlik kuralın olumsuz yönde yorumlama ve uygulama anlamına gelir. Oysa, kadın-erkek eşitliğinin amacı, her iki cinsin benzer ancak eşit olmayan yönlerinin olumlu doğrultuda hukuksal olarak eşit duruma getirilmesidir. Kuşkusuz, benzemeyen yönleri için yapılan farkl hukuksal düzenlemeler - örneğin kadına doğum izni verilmesi gibi - bu eșitliği etkilemez. Zira kadin ve erkeğin benzemeyen yönlerine ilişkin hukuk kurallarının amacı, eşitlĭgi sağlamak değil; her iki cinsin farklı özelliklerine hukuksal alanda çözüm getirmektir. Kadınla erkeğin eşitliği, iki cins arasındaki eşitsizliği yaratan değer yargılarının değiştirilmesini gerektirir. Çağlar boyu toplumların büyük kesiminde erkeğin kadına üstünlüğü yerleşik bir değer yargısı durumuna getirilmiş ve bu yargııın temelinde, kadının âciz, erkek tarafindan korunmaya muhtaç bir varlı (inbeccillitas sexus) olduğu varsayımı yer almıştır. Örneğin, onbirinci yüzyılda Çin felsefesi, kadının en aşağı bir mahlûk olduğunu, birlikte yaşadığı kişiler tarafindan acı çektirilmesinin doğal bulunduğunu savunuyordu. Ortaçağ Avrupa'sında da kadının eziyet edilmeye kendisini alş̧tırması öğretiliyor; erkeğin karısını dövmesi kilise hukukunda haklı bulunuyordu. Kocasını tehdit eden, hırsızlı yapan, rahibe karşı çıkan kadın öldürülüyordu. Semavi dinlerin kadının özgürlüğ̈̈nde ve haklarını kullanmada olumlu katkıları olmuşsa da, uygulamada kadın ve erkek eşitsizliği giderilememiștir.", (AYMK, 29.11.1990-1990-30/1990-31 sayll karar) ${ }^{70}$.

Anayasa Mahkemesi yine kadının zina fiilini suç olarak düzenleyen 765 sayılı mülga Türk Ceza Kanunu m. 440’a ilişkin verdiği bir başka kararında ise, "Türk Ceza Kanunu’nun 440. maddesinde, karının zinasının suç oluşturacağı öngörülmüş, kocanın zinasını suç sayan 441. maddesi ise Anayasa Mahkemesince iptal edilmiştir. Böylece, kocanın zinası suç olmaktan çıkmıştır. Evlilik birliğinin tarafları olarak karı ile aynı hukuksal konumda olması gereken koca için zinanın suç olmaktan çıkmasına karşın, karı için suç sayılmaya devam etmesi Anayasa'nın 10. maddesindeki "eşitlik" ilkesine aykırıllk oluşturmaktadır." hükmü iptal etmiştir (AYMK, 23.06.1998-1998-3/1998-29 sayılı karar) ${ }^{71}$.

69 AnayasaMahkemesikararıiçinbkz.<https://normkararlarbilgibankasi.anayasa.gov.tr/ND/1989/3?KararNo=1989\%2F3> Erişim Tarihi Erişim Tarihi 04.05.2021.

70 Anayasa Mahkemesi kararı için bkz. <https://normkararlarbilgibankasi.anayasa.gov.tr/ ND/1990/31?KararNo=1990\%2F31 > Erisim Tarihi 04.05.2021.

71 Anayasa Mahkemesi kararı için bkz. ND/1998/28?KararNo=1998\%2F28 > Erişim Tarihi 04.05.2021. 


\section{b. Yargıtay Kararları Bakımından}

Yargitay tarafından verilen kararlarda kullanılan dilde, toplumsal değerlerin, örf-adetin, geleneksel bakış açısının, kadın-erkek ilişkisinde taraflara yüklenen toplumsal rollerin yansımalarına sıklıkla rastlanmaktadır. Özellikle cinsel özgürlük ve dokunulmazlığa karşı suçlarda durum çok daha fazla görünür hale gelmektedir. 765 sayılı mülga Türk Ceza Kanunu döneminde, son dönemlerde azalmaya başlasa da, daha yoğun olarak izlenen bu durum, 5237 sayılı Türk Ceza Kanunu döneminde, çağın getirdiği gelişmelere de paralel olarak, daha azalmış durumdadır, ancak sonlandığını ifade etmek mümkün değildir.

Özellikle mülga Ceza Kanunu döneminde, yürürlükte bulunan suçların unsurları nedeniyle verilen kararlar toplumsal cinsiyet eşitliği bağlamında oldukça sorunlu, ayırımcı ifadeleri içinde barındırmaktadır. Yargıtay, mülga Ceza Kanunu’nun 423. maddesi kapsamında verdiği kararlarda kızlık bozma kavramını kızlık zarının yırtılması olarak ele almış ve suçla korunan hukuksal menfaatin bizzat kızlık zarı olduğu ifade edilmiştir ${ }^{72}$. Keza ırza geçme suçu bakımından madde düzenlemesi gereği failin sadece erkek olabileceği belirtilmiştir ${ }^{73}$. Ayrıca ırza geçme suçunda fiil, mağdurun mayubiyetine - ayıpl olmasına - neden olmuşsa cezanın artırılması öngörülmüştü (mülga 765 sayılı TCK m.418/2).

Mülga 765 sayılı Türk Ceza Kanunu döneminde de 5237 sayılı Türk Ceza Kanunu döneminde de yargı kararlarında dikkat çekici eşitlik ilkesine aykırı ayırımcı ifadelerin yer almasına ve uygulamaların yapılması neden olan başka bir ceza hukuku kurumu daha bulunmaktadır: Haksız tahrik. Hangi fiil ve söylemlerin haksız tahrik oluşturacağının belirlenmesinde kadın ve erkek arasında ayrım olduğu ve erkekten yana tavır alındığı maalesef Yargıtay kararlarında dikkati çeken bir durumdur. Haksız tahrik indiriminin uygulandığı bazı örnekler: Kadının; evde sigara içmiş olması, yemek hazırlamamış bulunması, izinsiz alışveriş yapmış olması, boşanmak istemesi gibi ${ }^{74}$. Şu kararlar dikkat çekicidir: “... her ne kadar katılan uyuyakaldiğı için zil sesini duymadığın beyan etmiş ise de sanık ile katılanın arasındaki geçimsizlik nedeniyle katılanin saniğ isteyerek kapıda bekletme ihtimalinin bulunduğu, bu nedenle sanık lehine yorumla sanık hakkında haksiz tahrik indirimi yapllmasinda bir isabetsizlik bulunmadiğindan...”, (Y3CD, 01.10.2013-2012-28544/2013-33263); “...mağdurenin eşinden izinsiz terlik satın alması ve eve gelen eşi sanığa yemek hazırlanmamış olması şeklindeki hareketlerinin samı lehine tahrik hükümlerinin uygulanmasın gerektirip gerektirmediğinin kararda tartışılması gerekir.", (Y2CD, 29.03.2000-3033/3281); “...katılan ve mağdur grubunun 'bir kıza sahip çıkamıyor, ne biçim erkek' şeklinde söz atmaları bardağ taşıran damla olmuştur. Kavgada, kendine güvenen hangi Türk erkeği olursa olsun bu sözün altında kalmak istemez. İnsanların özellikle bu tür suç işlemelerinde ulusal, töresel ve ahlaki ön yargıların ve alışkanlikların büyük rolü vardır. Değer yargıları itibariyle Türk erkeğinin karakteristik yapısl, kolay kolay bu sözü kendisine sindiremez.", (YCGK,

72 Yargitay Ceza Genel Kurulu, E. 359, K. 24, 19.01.1976; Yargitay Ceza Genel Kurulu, E. 105, K. 128, 14.12.1990. Kararlar için bkz. Toluay (no 54) 166.

73 Yargitay Ceza Genel Kurulu, E. 101, K. 56, 04.06.1990. Karar için bkz. Toluay (no 54) 167. Ayrıca bkz. Sulhi Dönmezer, Umumî Âdap ve Aile Nizamı Aleyhine Cürümler, (İstanbul Üniversitesi Yayınları 1945), 29; Ayhan Önder, Türk Ceza Hukuku, Özel Hükümler, (4. Bası Filiz Kitabevi 1994), 444. 
28.06.2011-114/150); “...Maktul ile sanığın annesi arasındaki ilişkinin cinsel ilişki boyutuna ulaşttğına dair delil bulunmamakta ise de; maktulün evliliği devam eden, eşi ve çocuklarıla birlikte yaşayan bir bayanın evine gündüzleyin gelmesi, sanı̆̆ı daha önce maktulü birkaç kez evlerinin önünde görmesi nedeniyle annesiyle maktul arasında ilişki olduğundan şüphelenmesi ve olay günü de maktulü ailece birlikte yaşadıkları evin içinde annesinin yanında görmesi, kendisinin eve mutfak kapısından girdiği sırada daire kapısından çıkan maktulün apartmanın girişinde babasıyla tartışmaya başlaması hususları birlikte değerlendirildiğinde, haksız tahrikin ulaştığı boyuta göre yerel mahkemece TCK'nun 29. madde uyarınca alt sinırdan uzaklaşılmak suretiyle takdir edilen haksız tahrik indiriminin adil ve yerinde olduğunun kabulü gerekmektedir" (YCGK, 20.5.2014-2013-1-528/2014-269) ${ }^{75}$.

Öte yandan, Yargıtay tarafından verilen kararlarda zaman zaman kadın ve erkek ayrımını ortaya koymak amacıyla kavramlara ilişkin farklı ifadeler kullanıldığı görülmektedir. Özellikle ve çoğunlukla cinsel suçlar bakımından yapılan bu ayrıştırma; "Sanığın, mağdurenin ellerinden tutarak "gel benim evime gidelim, seninle birlikte olmak istiyorum" şeklinde sözler söylediği iddia edilmiş olması karşısında, delillerin takdiri ve suç niteliğinin tayini görevinin üst dereceli Asliye Ceza Mahkemesine ait bulunduğu..." ${ }^{.76}$, toplumsal eşitlik esasına uygun görünmemektedir.

\section{TICARET HUKUKU (TICARI IŞLETME HUKUKU, ŞIRKETLER HUKUKU VE KIYMETLi EVRAK HUKUKU)}

Aşağıda ticaret hukukunda toplumsal cinsiyet eşitliğini ilgilendiren düzenlemeler üzerinde bir değerlendirme yapılırken, 6102 sayılı Türk Ticaret Kanununun (TTK) ${ }^{77}$ sırasıyla "Başlangıç" kısmı (m. 1 ila 10) ile "Ticari İsletme" (m. 11 ila 123), "Ticaret Şirketleri” (m. 124 ila m. 644) ve "Kıymetli Evrak" (m. 645 ila m. 849) olmak üzere ilk üç kitabında yer alan hükümleri esas alınacak ve ilgili ikincil mevzuata da yeri geldikçe değinilecektir. Ayrıca Türkiyede ticaret hayatında kadının yeri hakkında da kısaca bilgi verilmeye çalışılmıştır. Ancak daha önce de ifade edildiği gibi, bu kısımda da derslerin işlenişi sırasında öğrencilerin toplumsal cinsiyet ile ilgili dikkatlerine sunulmasının önemli olduğu düşünülen temel sorunlar kaleme alınmıştır.

\section{TÜRK TICARET KANUNUNUN BAŞLANGIÇ KISMI ILE TICARI IŞLETME, TICARET ŞIRKETLERI VE KIYMETLI EVRAK KITAPLARINDA KULLANILAN DIL BAKIMINDAN GENEL DEĞERLENDIRME}

Hükümlerin içeriğinin incelenmesine geçilmeden önce TTK'da genel olarak cinsiyete dayalı ayrıştırıcı bir dil kullanılmadığı belirtilmelidir. Kanunda "kadın" veya "erkek" kelimelerine hiç yer verilmemiş;

75 Hülya Aksakal, "Yargıtay Kararlarında Toplumsal Cinsiyet Eşitsizliği: “Erkekler Lehine İşleyen Haksız Tahrik Kurumu”', (2018), 1, Suç ve Ceza, Ceza Hukuku Dergisi, 25, 35-36, 38, <https://tchd.org.tr/Uploads/20181\%202.4.18.pdf\#page=28 $>$ Erişim Tarihi 09.05.2021.

76 Yargıtay 5CD, E. 2006-13201, K. 2007-7, 22.01.2007, aktaran, Leyla Çakıcı Gerçek, "Yargıtay Kararlarılla Cinsel Taciz Suçu”, (2011), 60 (1), AÜHFD, 47, 59, < https://dergipark.org.tr/tr/download/article-file/624642 > Erişim Tarihi 07.05.2021.

77 Türk Ticaret Kanunu, Kanun Numaras1: 6102, Kabul Tarihi: 13.01.2011, RG 14.02.2011/27846. 
bunlar yerine "taraf", "kişi”, "kimse”, "tacir”, "ilgili”, "işletme sahibi”, "hak sahibi”, "hamil”, "dilekçe sahibi" ya da "düzenleyen” gibi ifadeler tercih edilmiştir. Bu kelimeler dışında Kanunun ikinci kitabı olan “Ticaret Şirketleri” ile ilgili hükümlerde ise ayrıca "ortak”, "pay sahibi", "kurucu”, "üye”, "yönetici”, "tevdi eden" veya "müdür" gibi cinsiyetsiz kavramlara yer verilmiştir. Bu kısımda cinsiyete gönderme yapan bir ifade örneği olarak sadece TTK m. 195/4 anılabilir. Hüküm, şirketler topluluğunda hâkim şirketlerin "ana", bağlı şirketlerin de "yavru” şirket konumunda olduğunu açıklamaktadır.

Öte yandan, Kanunda bu eşitlikçi tutumun aksine bazı örneklerle de karşılaşılmaktadır. Konumuz kapsamındaki iki hükümde "adam" kelimesi kullanılmıştır" 78 Bunlardan birincisi, tacir olmanın sonuçlarından biri olan "basiretli bir iş adamı gibi hareket etme" zorunluluğunu düzenleyen TTK m. 18/2'dir. İkincisi ise aynı yükümü kollektif şirketlerde tasfiye memurları için getiren TTK m. 286/1'dir. "Basiretli bir iş adamı gibi hareket etme" yükümü, tacirin ticari işletmesiyle ilgili faaliyetlerinde kendi yetenek ve imkânları gereği ondan beklenebilecek özeni değil; aynı ticaret dalında faaliyet gösteren tedbirli ve öngörülü bir tacirden beklenen objektif özeni göstermesinin gerekli olduğunu öngörür ${ }^{79}$. Doktrinde ifade edildiği gibi, burada sorun, olumlu kabul edilen özellik ve yeterliliklere sahip bir insan olmanın "erkek" olmakla özdeşleştirilmiş; böylece kadın aleyhine cinsiyetçi bir dile yer verilmiş olmasidir ${ }^{80}$.

Şüphesiz, Kanunda "basiretli bir iş adamı gibi hareket etme" ifadesine yer verilmesi, erkekler dışında kalan tacirlerin bu yükümden muaf oldukları veya bu yükümü yerine getiremeyecekleri gibi bir anlayışın benimsendiği anlamına gelmez. Bu nedenle, bu ibare yerine rahatlıkla "basiretli bir iş insanı" ifadesi kullanılabilirdi ve böylece çok daha eşitlikçi bir yaklaşım benimsenmiş olurdu. Hatta Kanunun diğer maddeleri ile terim birliği sağlanması açısından TTK m. 110/2'de olduğu gibi "basiretli bir tacir" ibaresine de yer verilebilirdi ${ }^{81}$.

\section{TICARI IŞLETME HUKUKU NORMLARI BAKIMINDAN GENEL DEĞERLENDIRME}

Kanunun başlangıç kısmı ve ilk kitabı olan “Ticari İşletme” ile ilgili hükümler incelendiğinde, tacir olmak veya ticari bir işle uğraşmak bakımından cinsiyete dayalı herhangi bir ayrım gözetilmediği söylenebilirr ${ }^{82}$. TTK'da bulunmamasına rağmen, konuya ilişkin cinsiyetçi bir yaklaşım 1926 tarihli eski Türk Medeni Kanununda (eTMK) benimsenmiş durumda idi. eTMK m. 159 gereği, evli kadının

78 TTK’nın konumuz kapsamı dışındaki diğer hükümlerinde toplam 64 defa "adam” kelimesi geçmektedir. Bunlardan ikisi Kanunun "Taşıma İşleri” kitabında (m. 879; m. 929) ve kalanlar ise "Deniz Ticareti” kitabında "gemi adamı" ve "taşıyanın adamları" şeklinde yer almaktadır. Bu maddeleri toplu halde görmek için bkz. Damla Songur, "Toplumsal Cinsiyet Eşitliği Perspektifinden Ticaret Hukuku ve Uygulamasına Genel Bakış’ iç Gülriz Uygur ve Nadire Özdemir (edr) Hukuk ve Toplumsal Cinsiyet Çalışmaları (Seçkin 2018) 416, dn. 16.

79 ibid 416; Sabih Arkan, Ticari İşletme Hukuku (24. Baskı, Banka ve Ticaret Hukuku Araştırma Enstitüsü 2018) 151; Mehmet Bahtiyar, Ticari İşletme Hukuku (21. Baskı, Beta 2020) 119.

80 Songur (n. 78) 416.

81 Aynı yönde bkz. ibid 417. Songur, "basiretli bir iş adamı" yerine "tedbirli bir tacir" (TTK m. 928/2) ya da "tedbirli bir yönetici” (TTK m. 369/1) yahut “basiretli yönetici” ibarelerinin de kullanılabileceğini ifade etmiştir. Kanaatimizce, salt tedbir kelimesi "basiret” kavramını tam olarak karşılamadığı ve "yönetici” ile "tacir” kavramları ise birbirlerinden çok farklı anlamlar taşıdığı için yazarın bu görüşüne katılamıyoruz.

ibid 414 . 
bir iş görme ve meslekle uğraşması eşinin iznine bağlanmıştı. Ancak bu hüküm, 1990 yllında Anayasa Mahkemesi tarafından Anayasa’ya aykırı bulunarak iptal edilmiş ${ }^{83}$ ve böylece kadınların eşlerinden izin almaksızın ticari hayatta yer almalarının önü kanunen açılmıștı ${ }^{84}$.

Tacir sıfatının kazanılmasında olduğu gibi, tacir olmanın sonuçları açısından da cinsiyeti esas alan bir ayrım yapılmamıştır. Yukarıda da belirtildiği üzere, bunlardan biri olan "basiretli bir iş adamı gibi davranma" yükümü cinsiyeti fark etmeksizin bütün tacirler bakımından uygulanır. Benzer şekilde, ticaret siciline kayıt, ticaret unvanı veya işletme adı kullanma, ticari defterler tutma, cari hesap sözleşmesi akdetme ve 6098 sayılı Türk Borçlar Kanununda (TBK $)^{85}$ düzenlenen diğer tacir yardımcıları da dâhil olmak üzere, acenteliğe ilişkin hükümlerde öngörülen şartlar, ortaya çıkan hukuki sonuçlar ve yükümlülükler açısından da cinsiyete dayalı hiçbir ayrım bulunmamaktadır.

Konumuz kapsamında değinmemiz gereken tek hukuki düzenleme haksız rekabeti ilgilendirmektedir. Haksız rekabetin özel bir hali olan "haksız ticari uygulamalar", 6502 sayılı Tüketicinin Korunması Hakkında Kanun (TKHK) ${ }^{86}$ m. 61, m. 62, m. 63 ve m. 84 hükümlerine dayanılarak çıkarılan "Ticari Reklam ve Haksız Ticari Uygulamalar Yönetmeliğı”"87 ile düzenlenmiştir. Uygulama alanı TTK’nın haksız rekabete ilişkin hükümlerine nazaran sınırlı olmakla birlikte, Yönetmelik, tüketicilerin ekonomik çıkarlarının korunması amacıyla aldatıcı ve yanıltıcı reklamlar ile tüketicilere yönelik aldatıcı veya dürüstlük kurallarına aykırı ticari uygulamaları yasaklamaktadır. Yönetmeliğin iki ayrı maddesinde "cinsiyeti" dikkate alan düzenlemeler getirilmiştir:

Bunlardan birincisi, reklamlarla ilgili temel ilkelerin düzenlendiği m. 5’tir. Buna göre, reklamlar, "dil, ırk, renk, cinsiyet... ve benzeri özelliklere yönelik kötüleme, istismar, önyargı veya ayrımcılık içeremez" (m. 5/1/d bendi). Hükümde açıkça cinsiyete de dayalı ayırımcılık yasağı getirilmiştir. Bu noktada reklamın konusu olan mal veya hizmetin kadın ya da erkeğe hitap etmesi ile reklamda cinsiyete yönelik bir ayırımcılık yapılması birbirinden ayrılmalıdır. Bilindiği gibi, her reklam belirli bir hedef kitleye yönelir. Hedef kitle, mal ya da hizmeti satın alan yahut alacak olan kişi ve gruplar ile mal veya hizmeti satın almayan ancak satın alınmasına karar veren veya satın alınmasına etki eden kişilerdir (çocuklar, eşler, arkadaşlar vs.). Reklamın hedef kitlesi belirlenirken yaş, cinsiyet, meslek, gelir, ilgi alanları gibi unsurlar dikkate alınır ${ }^{88}$. İște kadınlar da reklamcılar tarafından iki nedenle reklamda kullanılmaktadır: Reklamın hedef kitlesi oldukları için veya başkalarını etkilemek ve ikna etmek için. Erkeklerin hedef kitle olduğu reklamlarda kadınların güzel, çekici, genç kadın olarak sunumu

83 Anayasa Mahkemesi, E 1990/30 K 1990/31, 29.11.1990.

84 Bahtiyar (n. 79) 109; Aynur Yongalık, 'Pozitif Ayrımcılığın Aracı Olarak Hukuk: Şirket Yönetim ve Denetim Kurullarında Kadın Kotası Uygulaması', iç Fatma Güven Lisaniler ve Süheyla Üçışık Erbilen (edr) Toplumsal Cinsiyet Eşitliği ve Hukuk: 4. Uluslararası Kadın/Toplumsal Cinsiyet Çalışmaları Konferansı, Bildiri Özetleri Kitabı (2012) 5; Songur (n. 78) 414-415.

85 Türk Borçlar Kanunu, Kanun Numarası: 6098, Kabul Tarihi: 11.01.2011, RG 04.02.2011/27836.

86 Tüketicinin Korunması Hakkında Kanun, Kanun Numarası: 6502, Kabul Tarihi: 07.11.2013, RG 28.11.2013/28835.

87 Ticari Reklam ve Haksız Ticari Uygulamalar Yönetmeliği, RG 10.01.2015/29232.

88 Ferzinde Kaya, 'Reklam ve Pazarlama Stratejileri: Bir Reklamda Olması Gerekenler' (2018) 3(5) Mecmua Uluslararası Sosyal Bilimler Dergisi 99, 101. 
ikinci ihtimale bir örnektir ${ }^{89}$. Bu durum, Yönetmelik m. 5/1/d bendini her zaman ihlal etmese de, kadınların reklamda cinsel meta haline getirilmesi de cinsiyet eşitliğine zarar veren bir tutumdur.

İkincisi ise fiyat bilgisi içeren reklamlara ilișkin m. 13/3’tür. Madde gereği, fiyat içeren reklamlarda “tüketicinin yaş, cinsiyet, sağlık durumu gibi özellikleri” nedeniyle bir vergi, resim, harç veya ücretin hesaplanamaması durumunda bu unsurların fiyata dâhil olmadığg ve toplam fiyatın hesaplanma yöntemi reklamlarda açıkça belirtilir.

Öte yandan, ticaret hukuku açısından cinsiyet eşitsizliğinin daha çok uygulamada ortaya çıktığını ve ticaret hayatına katılan kadın ve erkek sayısının eşit olmadığını söylemek mümkündür. "Türkiye Kadın Girişimciler Derneği” (KAGİDER) tarafından 2018 yılı verileri esas alınarak kadın girişimciler (tek başına ya da ortaklarıyla birlikte sermaye koyarak üretim amacıyla bir işe başlayan kadınlar) ${ }^{90}$ üzerinde yürütülen ve 2019 'da sonuçları yayımlanan araştırmaya göre, Türkiye girişimciliğin yüksek oranda bir kariyer tercihi olarak görüldügü az sayıda ülkeden biri olmasına rağmen, kadın girişimcilerin sayısı erkek girişimcilerin yarısından daha azdır. Kadın girişimcilerin oranı \%9 civarında kalmaktadır ${ }^{91}$.

Kadın girişimcilerin kurdukları girişimlerin faaliyet alanları incelendiğinde ise önde gelen sektörün hizmet sektörü (eğitim, danışmanlık, halkla ilişkiler, tekstil, sağlık) olduğu göze çarpmaktadır ${ }^{92}$. Öğretide bu tercihin, biyolojik açıdan sahip olunan cinsiyet özellikleri yanında daha az sermaye ve donanım gerektirmesi ve kadına iş ve aile yaşamını dengeleme olanağı sağlaması gibi sebeplerden kaynaklandığı ileri sürülmüştür ${ }^{93}$. Ancak kanımızca, bu yorum cinsiyetçi olup kadına verilen toplumsal rolün ve kadına yönelik beklentilerin etkisi altında kalmıştır.

Ülkemizde kadın girişimcileri teşvik etmek ve geliştirmek amacıyla bazı kurum ve kuruluşlar tarafından çeşitli destek programları yürütüldüğü belirtilmelidir. Bunlar arasında, Küçük ve Orta Ölçekli İşletmeleri Geliştirme ve Destekleme İdaresi Başkanlığınca (KOSGEB) verilen "Kadın Girişimci Kredi Desteği”", Türkiye Odalar ve Borsalar Birliği (TOBB) bünyesinde kadın girişimcilere eğitim vermek ve iş fikirlerini hayata geçirmeleri için destek sağlamak üzere kurulan

89 Duygu Dumanlı, 'Reklamlarda Toplumsal Cinsiyet Kavramı ve Kadın İmgesinin Kullanımı; Bir İçerik Analizi’ (2011) 1(2) Yalova Sosyal Bilimler Dergisi 132, 134. Zaman içinde yaşanan toplumsal değişimin reklamlardaki kadın imgesi üzerindeki etkisi hakkında ayrıntılı bilgi için ayrıca bkz. Dumanlı (n. 89) $135 \mathrm{vd.}$

90 Girișimci kavramı ve girişimcilik türleri hakkında ayrıntılı bilgi için ayrıca bkz. Burcu Kılınç Savrul ve Dalga Akyüz, ‘Türkiye Ekonomisinde Kadın Girişimcilerin Mevcut Durumu ve Geliştirilmesine Yönelik Çözüm Önerileri' (2016) 11(1) ÇÖMÜ Girişimcilik ve Kalkınma Dergisi 165, 170 vd.

91 Türkiye Kadın Girişimciler Derneği (KAGİDER), 'Türkiye Kadın Girişimcilik Endeksi - 2019 Araştırma Raporu' (Cinsiyet Eşitliği İzleme Merkezi, 2019) <https://dspace.ceid.org.tr/xmlui/handle/1/427> Erişim Tarihi: 20.04.2021.

92 Sevtap Keskin, 'Kadın ve Erkek Girişimciler Arasındaki Farklılıklar' (2017) 1(1) Mersin Üniversitesi Sosyal Bilimler Enstitüsü e-Dergi 64, 68. Aynı yönde bkz. Kılınç Savrul ve Akyüz (n. 90) 167. Kadın ve erkek girişimciler arasında görülen amaç, yaptıkları hazırlık, yaş, iş stratejileri, kurdukları organizasyon, beklentileri, kaynak ve sektör seçimi gibi çeşitli farklılıklar hakkında ayrıntılı bilgi için ayrıca bkz. Keskin (n. 92) 67 vd.

93 Keskin (n. 92) 67; Nazan Yelkikalan, 'Başarılı Girişimcilikte Cinsiyetin Rolü: Kadın Girişimciler' (2006) 1(1) ÇÖMÜ Girişimcilik ve Kalkınma Dergisi 45, 50.

94 Ayrıntılı bilgi için ayrıca bkz. KOSGEB Kadın Girişimci Desteği <https://devletkredileri.com/kosgeb-kadin-girisimcidestegi/> Erişim Tarihi 22.04.2021. 
"Kadın Girişimciler Kurulu"95 ya da Aile ve Sosyal Hizmetler Bakanlığınca sağlanan faizsiz ve uzun vadeli kredi desteği sayılabilir ${ }^{96}$. Tüm bu olumlu gelişmelere rağmen, kadın girişimcilerin oranı göz önünde alındığında, teşvik programlarının yeterli düzeyde olduğunu söylemek pek mümkün gözükmemektedir. Kadınları ekonomik hayata çeken, eğitim ve bilinç düzeylerini yükselten, onları cesaretlendiren ve girişimcilik özelliklerini güçlendiren yeni politikalara ihtiyaç duyulduğu açıktır ${ }^{97}$.

\section{3. ŞIRKETLER HUKUKU NORMLARI BAKIMINDAN GENEL DEĞERLENDIRME}

TTK’nın ikinci kitabı olan “Ticaret Şirketleri” ile ilgili hükümler incelendiğinde de ne genel hükümler arasında ne de şirket tiplerine özgü özel hükümlerde cinsiyetçi bir söyleme yer verildiği söylenebilir.

Ticaret şirketlerinin sözleşmelerinde bulunması gereken unsurlar arasında ortakların, yönetici veya temsilcilerin cinsiyetine ilişkin bir bilgiye yer verilmemiş; ortak, yönetici ya da temsilci olma ehliyeti, yetkileri, hak ve yükümlülükleri bakımından cinsiyete dayalı bir ayrıma da gidilmemiştir. Hatta anonim (TTK m. 357) ve limited şirketlerde (TTK m. 627) geçerli olan "eşit işlem ilkesi”, pay sahiplerinin/ortakların eşit şartlarda eşit işleme tâbi tutulacaklarını kanunen güvence altına almıştır. İlke, sadece aynı durumda bulunan pay sahipleri/ortaklar arasında eşitliği kabul ettiğinden kural olarak nispi niteliktedir. Ancak aynı zamanda Anayasa'ya da aykırı olan özellikle dil, din, ırk, cinsiyet, siyasi düşünce, felsefi inanç ve mezhep ayrılığı gibi farklılıklar temel alınarak gerçekleştirilen işlemlerde eşitlik ilkesi mutlak şekilde uygulanmalıdır ${ }^{98}$. Dolayısıyla örneğin, sırf kadın olduğu için bir pay sahibinin kâr payının erkek pay sahiplerinden daha az hesaplanması ilkeye aykırılık teşkil eder ${ }^{99}$.

Diğer taraftan, TTK'da şirket ortakları, yönetici veya temsilcileri arasında kadınların bulunması zorunluluğuna yer verilmemiştir. Buna karşılık, Sermaye Piyasası Kurulu (SPKr) tarafından kurumsal yönetim ilkelerini belirlemek üzere 6362 sayılı Sermaye Piyasası Kanunu (SPKn) ${ }^{100}$ m. 17’ye dayanılarak yayımlanan II-17.1 sayılı "Kurumsal Yönetim Tebliği"101 ile hemen aşağıda açıklayacağımız üzere, farklı bir anlayış benimsenmiştir. Tebliğde, payları borsada işlem gören anonim şirketler için uyulması zorunlu olan ilkeler tek tek sayılmıştır (II-17.1 sayılı Tebliğ m. 5/1). Uyulması zorunlu tutulmayan tavsiye niteliğindeki ilkeler bakımından "uygula, uygulamıyorsan açıkla" (comply or explain) prensibi geçerlidir (II-17.1 sayılı Tebliğ m. 8/1).

95 Resmi web sayfası için bkz. https://www.tobb.org.tr/TOBBKadinGirisimcilerKurulu/Sayfalar/AnaSayfa.php.

96 Ayrıntılı bilgi ve diğer örnekler için ayrıca bkz. Kamuajans, ‘Girişimci Kadınlara 2021 Yılı Destek Veren Kamu Kurumları ve Sivil Toplum Örgütleri' (Kamuajans, 16.06.2021) <https://www.kamuajans.com/> Erişim Tarihi: 26.09.2021.

97 Aynı yönde bkz. Kılınç Savrul ve Akyüz (n. 90) 182.

98 Şükrü Yıldız, Anonim Ortaklıkta Pay Sahipleri Açısından Eşit İşlem İlkesi (Seçkin 2004) 88; Akın Murat Yusuf ve Setenay Yağmur, 'Türk Anonim Şirketler Hukukunda Eşit İşlem İlkesinin Uygulanması Açısından Objektif Kriter Kavramı' (2018) 13(144) Terazi Aylık Hukuk Dergisi 96, 103.

99 Akın ve Yağmur (n. 98) 103.

100 Sermaye Piyasası Kanunu, Kanun Numarasi: 6362, Kabul Tarihi: 06.12.2012, RG 30.12.2012/28513.

101 Kurumsal Yönetim Tebliği, RG 03.01.2014/28871. 
II-17.1 sayılı Tebliğin ekinde yer alan kurumsal yönetim ilkelerinin dördüncü bölümü "yönetim kurulu” ile ilgili ilkelere ayrılmıştır. Bu bölümde "Yönetim Kurulunun Yapısı" başlı̆̆ı altında düzenlenen 4.3.9 numaralı ilke gereği, "şirket, yönetim kurulunda kadın üye oranı için \%25'ten az olmamak kaydryla bir hedeforan ve hedef zaman belirler ve bu hedeflere ulaşmak için politika oluşturur. Yönetim kurulu bu hedeflere ulaşma hususunda sağlanan ilerlemeyi yillık olarak değerlendirir". İlke, kadınların iş dünyasına daha etkin bir biçimde katılarak söz sahibi olmalarına ve dolayısıyla cinsiyet eşitliğinin sağlanmasına hizmet etmesi bakımından yerindedir ${ }^{102}$. Ancak 4.3.9 numaralı ilke, II-17.1 sayılı Tebliğ m. 5/1'de uyulması zorunlu ilkeler arasında sayılmamıştır. Bu nedenle, II-17.1 sayılı Tebliğe tâbi payları borsada işlem gören şirketler ilkeyi uygulamıyorlar ise yıllık faaliyet raporlarında uygulamamalarının gerekçesini açıklamaları yeterlidir (II-17.1 sayılı Tebliğ m. 8/1).

Türkiyede 2020 yılı itibariyle payları Borsa İstanbul'da (BIST) işlem gören 397 şirketin 134’ünün yönetim kurulunda en az bir kadın üye bulunmaktadır. Bir önceki yıl \%15.9 olan toplam kadın üye oranı ise $\% 17^{\prime}$ ye ulaşmıştır ${ }^{103}$. Kaydedilen yavaş iyileşmeye rağmen bu veriler, tavsiye niteliğindeki düzenlemelerin kadın yönetici oranı bakımından Türkiyede beklenen ivmeyi yaratmadığını ve bağlayıcı kurallar getirilmesi gerektiğini göstermektedir ${ }^{104}$.

II-17.1 sayılı Tebliğin ekinde yer alan kurumsal yönetim ilkelerinin üçüncü bölümünde ise "menfaat sahipleri" ile ilgili ilkeler düzenlenmiştir. Bu bölümde "Şirketin İnsan Kaynakları Politikası" başlı̆̆ı altında öncelikle "işe alım politikaları oluşturulurken ve kariyer planlamaları yapılırken eşit koşullardaki kişilere eşit fırsat sağlanması ilkesinin” benimsenmesi gerektiği açıklanmıştır (3.3.1). İşe alım aşamasında eşitlik "eşit koşullardaki kişiler" arasında söz konusu olacağından adaylar öğrenim derecesi, yaş, kıdem, bilgi, tecrübe, yetenek gibi nitelikler dikkate alınarak seçilmeli; cinsiyete dayalı bir ayrım yapılmamalıdır. Nitekim görevin devam ettiği süre içinde de "çalışanlara sağlanan tüm haklarda adil davranılması" (3.3.3) ve "çalışanlar arasında ırk, din, dil ve cinsiyet ayrımı yapılmaması ve çalışanların şirket içi fiziksel, ruhsal ve duygusal kötü muamelelere karşı korunması için önlemler alınması" (3.3.7) gerekir. Ancak bu ilkeler de uyulması zorunlu ilkeler arasında sayılmamıştır (II17.1 sayılı Tebliğ m. 5/1).

Tüm dünyadan 44 farklı ülkede ve 50 sektörde faaliyet gösteren 380 şirketi içeren Bloomberg Cinsiyet Eşitliği Endeksi (Bloomberg Gender-Equality Index/GEI), cinsiyet eşitliği konusundaki performanslarına göre halka açık anonim şirketler arasında bir sıralama sunmaktadır. Halka açık anonim şirketler, üst yönetim kadrolarında kadınlara yer verme, terfi süreçlerinde eşitlik, ücrette eşitlik, cinsel tacizle mücadele politikaları ve kadın dostu marka kimliği (kadınlara yönelik ürün geliştirme, kadın girişimcileri ve tedarikçileri destekleme, müşteri ve çalışan dışındaki kadınların finansal okuryazarlığına destek olma vs.) gibi alanlarda değerlendirilmekte ve performans ve

102 Aynı yönde bkz. Erdal Demir, Sermaye Piyasası Kurulu’nun Anonim Şirketlerdeki Yönetim Kuruluna İlişkin Kurumsal Yönetim İlkeleri (Oniki Levha 2013) 102-103.

103 Sabancı Üniversitesi Kurumsal Yönetim Forumu, ‘Türkiye’de Yönetim Kurulunda Kadınlar' (Yönetim Kurulunda Kadın Derneği, 2020) <https://www.yonetimkurulundakadin.org/assets/node_modules/source/pdf/sabanci-2020-8th_yillik_ rapor.pdf> Erişim Tarihi: 25.04.2021.

104 Aynı yönde bkz. Songur (n. 78) 422; Demir (n. 102) 103. 
şeffaflıkları çerçevesinde belirli bir skorun üstünde not alan şirketler endekse dâhil olmaktadır ${ }^{105}$. 2021 yılı itibariyle endekste Ford Otomotiv Sanayi AŞ, Türkiye Vakıflar Bankası TAO, Yapı ve Kredi Bankası, Garanti BBVA ve Akbank olmak üzere beş Türk şirket yer almıştır ${ }^{106}$.

Son olarak belirtilmelidir ki, II-17.1 sayılı Tebliğin ekinde yer alan 3.5.2 numaralı ilkede şirketlere ayrıca "sosyal sorumluluklarına karşı duyarl olmaları" tavsiye edilmiştir. Kurumsal sosyal sorumluluk, en genel anlamda, şirketlerin daha iyi bir toplum ve çevre için gönüllü olarak çalışmaları anlamına gelir. Böylece şirketler hem toplumsal sorunların çözümüne katkıda bulunmakta hem de piyasadaki prestijlerinin ve kendilerine duyulan güvenin artmasını sağlamaya çalışmaktadırlar. Türkiye'de de pek çok şirket tarafından sosyal sorumluluk projeleri kapsamında başta eğitim olmak üzere, çevre, sosyal destek, kültür-sanat, sağlık, ekonomi, spor, farkındalık ve şiddetin önlenmesi başlıkları altında çeşitli kampanyalara imza atıldığı görülmektedir. Bunlar arasında toplumsal cinsiyet eşitliğini savunan ve destekleyen projeler de vardır. Ülkemizde en çok ses getirenlerden biri, Turkcell tarafından yürütülen "Kardelenler" projesi olmuştur. Proje, ailelerin maddi yetersizlikleri nedeniyle öğrenimlerine devam edemeyen kız çocuklarına eğitimde fırsat eşitliği sağlanması, kızların meslek sahibi olmaları ve ufku açık bireyler haline gelmeleri için desteklenmelerini amaçlamıştır. Kadınlara yönelik kurumsal sosyal sorumluluk projelerinden bir diğeri olan ve Teknosa tarafından 12 yıldır sürdürülen "Kadın İçin Teknoloji" projesi ise kadınlara sosyal çevrelerini genişletme, işlerinde ve e-devlet işlemlerinde teknolojiyi kullanmanın yanı sıra sosyal medya üzerinden el emeği ürünlerini satma imkânı da sunmaktadır ${ }^{107}$.

\section{KIYMETLI EVRAK HUKUKU NORMLARI BAKIMINDAN GENEL DEĞERLENDIRME}

TTK’nın üçüncü kitabı olan "Kıymetli Evrak" ise bütün borç senetlerine uygulanan genel hükümler yanında kambiyo senetleri, kambiyo senetlerine benzeyen senetler ve diğer emre yazılı senetler ile makbuz senedi ve varanta ilişkin özel hükümleri düzenlemektedir. "Senetler hukuku" da denilen bu bölümde, toplumsal cinsiyeti ilgilendiren ya da toplumsal cinsiyet eşitliğini ihlal eden yahut destekleyen herhangi örnek bir hüküm yer almamıştır.

\section{YARGI KARARLARINDA}

Ticaret hukuku ile ilgili yargı kararları arasında, tespit edebildiğimiz kadarılya, toplumsal cinsiyet eşitliği bakımından dikkat çekici olabilecek karar sayısı yok denecek kadar azdır. Nitekim ister ilk derece ister üst mahkemelerin olsun, kararlarda kullanılan dil ve içeriğin, TTK'da da olduğu gibi cinsiyet eşitliğine aykırı bir nitelik taşımadığı söylenebilir.

105 Resmi web sayfası için ayrıca bkz. https://www.bloomberg.com/gei/.

1062021 yllı itibariyle Bloomberg Cinsiyet Eşitliği Endeksinde yer alan şirketleri görmek için ayrıca bkz. <https://assets. bbhub.io/company/sites/46/2021/01/GEI2021_MemberList_FNL.pdf> Erişim Tarihi 13.04.2021.

107 Ayrıntılı bilgi ve benzer örnekler için bkz. Özlem Bay Yılmaz, 'Topluma Değer Katan Şirketler', Ekonomist (29.12.2019) $<$ https://www.ekonomist.com.tr/dosya/topluma-deger-katan-sirketler.html> Erişim Tarihi 13.04.2021. 
Toplumsal cinsiyet eşitliği açısından ilk olarak marka devir sözleşmesinin hile, tehdit (ikrah) ve aşırı yararlanma (gabin) nedeniyle iptali ve dava konusu markanın hükümsüzlüğü talebiyle açılan bir davada geçen ifadelere değinilmelidir. Davada ilk derece mahkemesi, “...aşııı yararlanmanın kabul edilebilmesi için objektif unsurlarının yanında sübjektif unsurlarının da gerçekleşmesi gerektiği, davacının kadın olmasının düşüncesizlik deneyimsizlik olarak nitelendirilemeyeceği, sözleşmeyi imzalarken bedelin düşüklüğünü ve markayı devrettiğinin farkında olduğu gerekçesi ile davanın reddine” karar vermiştir. Karar, davacılar tarafindan önce istinaf mahkemesine ve istinaf isteminin esastan reddi üzerine Yargıtay’a götürülmüş; Yargıtay kararı onamıştır ${ }^{108}$. Karardaki ifadelerin, cinsiyet eşitliğine uygun olduğu düşünülebilirse de davacı marka sahibinin "kadın” olmasının düşüncesizlik ve deneyimsizliğe yol açabileceğinin tartışılmış olması, kadının ticari hayattaki yerine zarar veren bir tutumdur.

İkinci olarak ise TTK m. 369 hükmünün gerekçesinde de yer verilen ve bu nedenle, Türk ticaret hukuku literatüründe yerleşik bir kavram haline gelmiş olan bir ilkeden söz etmek gerekir. Türkçeye "iş adamı kararı" (business judgment rule) ${ }^{109}$ olarak çevrilen ilke, Amerika Birleşik Devletleri ve Almanya'da pek çok mahkeme kararına dayanak oluşturmuştur. İlke, mahkemelerin, anonim şirketin yönetimi ile ilgili kararları yerindelik açısından incelemelerini engelleyerek, yönetim kurulu üyelerinin özen yükümlülüklerinin ihlali nedeniyle açılan davalarda sorumluluklarını sınırlandırmayı sağlayan genel bir prensibi ifade etmektedir ${ }^{110}$. Buna göre, yönetim kurulu uygun araştırmaları yapıp gerekli bilgileri alarak karar vermişse ve bu kararın şirketin menfaatine uygun olduğu makul olarak kabul edilebiliyorsa olaylar aksi yönde gelişse ve şirket zarar etse bile yöneticinin özen yükümüne uygun hareket ettiği kabul edilir. Diğer bir deyişle, meydana gelen zarardan sorumluluk doğmaz ${ }^{111}$.

Görüldüğü gibi, yönetim kurulu üyelerinin kararlarından doğan sorumluluklarını ilgilendiren bu kavram, üyelerin sadece erkeklerden oluştuğu/oluşması gerektiği gibi yanlış bir izlenim yaratmaktadır. Üstelik doktrinde de belirtildiği üzere, ilkenin amacı dikkate alındığında, “iş adamı kararı” ifadesinin kavramı doğru şekilde açıkladığı da söylenemez. Bu nedenle, bire bir çeviri yapılarak “ticari takdir kuralı"112, "ticari değerlendirme kural»"113 ya da "ticari takdir ilkesi”"114 şeklinde ifade edilmesi, hem kavramın daha iyi anlaşılması hem de cinsiyetçi bir söyleme yer verilmemesi bakımından uygun olurdu.

108 Yargitay 11 HD, E 2019/5056 K 2020/3098, 23.06.2020.

109 "Business judgment rule" ifadesinin karşılığı olarak “iş adamı kararı" kavramını kullanan yazarları görmek için bkz. Sevgi Bozkurt Yaşar, Anonim Şirketlerde İşadamı Kararı İlkesinin (Business Judgment Rule) Uygulanması (Beta 2015) 3, dn. 3.

110 ibid 5.

111 Hasan Pulaşlı, ‘Türk Ticaret Kanunu Tasarısı'na Göre Anonim Şirket Yönetim Kurulu Üyelerinin Özen Yükümlülüğü ve Müteselsil Sorumluluğu' (2009) 25(1) BATİDER 27, 58. İş adamı kararı ilkesinin uygulanma şartları hakkında ayrıntılı bilgi için ayrıca bkz. ibid 59 vd.; Pulaşlı (n. 111) 59-63.

112 Bozkurt Yaşar (n. 109) 4.

113 Kürşat Göktürk, 'Amerikan, Alman, İsviçre ve Türk Hukukunda İşadamı Kararı İlkesi' (2011) 2(2) İnönü Üniversitesi Hukuk Fakültesi Dergisi 207, 209.

114 ibid 210 . 


\section{SIGORTA HUKUKU}

Gündelik hayatta çeşitli risklerle karşı karşıya kalmaktayız. Bu risklerin farklı yol ve yöntemlerle bertaraf edilmesi, doğurabileceği zararların azaltılması mümkün olabilmektedir. Zararların azaltılması ve tali bir koruma olarak günümüzde kabul gören en güvenli yöntemin sigorta himayesi olduğu tartışmasızdır. Sigorta dediğimizde aklımıza farklı sınıflandırmalar gelebilmektedir ki, bu ayrımlardan en temel olanı sosyal sigorta ve özel sigorta ayrımıdır. Çalışmamız 6102 sayılı Türk Ticaret Kanunu (TTK) kapsamında düzenlenen özel sigorta düzenlemeleri çerçevesinde alınacağından, sosyal sigorta çalışmada inceleme konusu yapılmamıştır.

TTK kapsamında sigorta hukukuna ilişkin düzenlemelere, yasanın altıncı kitabında rastlamaktayız. Altıncı kitap bünyesinde, sigorta sözleşmesinin tanımı, tüm sigorta sözleşmelerine uygulanacak genel hükümler ve sigorta türleri ile bu türlere özgü düzenlemeler kaleme alınmıştır. Sigorta hukukunda mevzuat bağlamında tek kaynak TTK altıncı kitap olmayıp, sigortacılık faaliyetinin işleyişi, sigortacılık alanındaki aktörlerden sigorta şirketleri, reasürans şirketleri, sigorta aracılarından acente ve broker gibi kurumların çalışma ve kuruluş esasları, faaliyetleri ve sona ermelerine yönelik düzenlemeleri içeren 5684 sayılı Sigortacılık Kanunu (SigK) ${ }^{115}$ bulunmaktadır. TTK ve SigK dışında, sigorta hukukuna dair çeşitli düzenlemeler ve ikincil kaynaklar söz konusu olmaktadır ${ }^{116}$.

\section{TÜRK TICARET KANUNUNUN SIGORTA HUKUKUNA ILIŞKIN DÜZENLEMELERI VE SIGORTACILIK KANUNU, DIĞER DÜZENLEMELER BAĞLAMINDA KULLANILAN DIL BAKIMINDAN GENEL DEĞERLENDIRME}

\section{a. Türk Ticaret Kanununun Sigorta Kitabı Normları Bakımından Genel Değerlendirme}

TTK sigorta hukukuna ilişkin hükümleri sistematik bir çerçevede düzenlenmiştir. Kanun koyucu birinci kısımda “Genel Hükümleri”, ikinci kısımda, birinci bölüm başlı̆̆ı altında “Zarar Sigortaları”nı, ikinci kısım ikinci bölümde ise "Can Sigortaları”nı kaleme almıştır. Kanun metni (m. 1401-1520) külli olarak incelendiğinde "kadın", "erkek" gibi ifadelerinin kullanılmadığı görülmektedir. Kanunda kullanılan ifadeler "sigortacı", "sigorta ettiren", "sigortalı", "lehtar”, "sigorta yapan”, "temsilci”, "adına sigorta sözleşmesi yapılan kişi”, "taraf/lar” vb. şeklindedir. Kanunda bahsi geçen ve belirttiğimiz ifadelerin dışında, Kanunun ikinci kısım ikinci bölümünde "Can Sigortaları" başlığı altında düzenlenen "Hastalık ve Sağlık Sigortaları" kapsamında m. 1517'de "ana” ve "baba” ifadelerine yer verilmiştir. İlgili düzenleme: "Doğum sırasında, ana babadan biri için yaptırılmış bir hastalık ve sağlık sigortasının bulunması halinde, aksi kararlaştırılmamışsa, doğumun tamamlanmasından itibaren bebek, ek prim olmaksızın sigortanın kapsamına girer..” şeklindedir. Hüküm nazara alındığında

115 03.06.2007 Kabul Tarihi, RG. 14.06.2007/ 26552

116 Sigorta hukukuna ilişkin diğer kaynaklar: 6098 sy. Türk Borçlar Kanunu (TBK), 1163 sy. Kooperatifler Kanunu (KoopK), 2918 sayılı Karayolları Trafik Kanunu (KTK), 4632 Bireysel Emeklilik Tasarruf ve Yatırım Sşstemi Kanunu (BES), 6502 sy. Tüketicinin Korunması Hakkındaki Kanun (TKHK), Genel Şartlar, Özel Şartlar, Yönetmelik, Tebliğ, Sektör Duyuruları, İçtihatlar ve Öğreti vb. 
içerisinde her ne kadar cinsiyete gönderme yapan ifadeler olsa da, bu kelimeler madde metninin tümü nazara alınarak birlikte değerlendirildiğinde ayrıştırıcı bir amaç gütmediği görülmektedir.

\section{b. Sigortacılık Kanunu Normları Bakımından Genel Değerlendirme}

Sigortacılık Kanunu kapsamında kullanılan dil açısından yaptı̆̆ımız inceleme neticesinde, kanun koyucunun cinsiyetsiz, ayırımcı olmayan bir dil kullandığını görmekteyiz. Bahse konu Kanun içerisinde, "aktüer", "sigorta brokeri”, “reasürans brokeri”, “eksper”, "şirket kurucuları, ortakları", "denetçi”, "sigortalı", “lehtar", “acente”, "sigorta hakemi”, "sigorta raportörü”, "nitelikli personel” vb. gibi ifadeler yer almaktadır. Bu ifadelerden de anlaşılacağı üzere, tıpkı TTK'da olduğu gibi, SigK kapsamında ayırımcılığa mahal vermeyecek ifadeler hakimdir.

\section{c. Diğer Düzenlemelerde - Özellikle Genel Şartlarda - Yer Alan Normlar Bakımından Genel Değerlendirme}

Sigorta sözleşmelerinin ayrılmaz bir parçası olan ve hiyerarşik sıralamada da birçok kaynaktan önce gelen genel şartlar, sigorta sözleşmesinin şekillenmesinde, tarafların borç ve yükümlülüklerinin tespitinde önem taşımaktadır. Bu nedenledir ki, genel ve özel şartlar TTK’nın altıncı kitabında düzenlenen sigorta hukukunun kaynak açısından ayrılmaz bir parçasıdır. Bu çerçevede TTK ve SigK'daki kanun dilini çalışma konumuz çerçevesinde incelediğimiz gibi genel şartları da bu kapsamda değerlendirmenin tartışmasız olacağı kanısındayız. Genel şartları uygulamada çeşitli sınıflara bölmek mümkün olabilmektedir. En bilinen şekliyle genel şart türleri;

- Can Sigortaları

- $\quad$ Ferdi Kaza Sigortası Genel Şartları

- Hayat Sigortası Genel Şartları

- Karayolu Yolcu Taşımacılığı Zorunlu Koltuk Ferdi Kaza Sigortası Genel Şartları

- Maden Çalışanları Zorunlu Ferdi Kaza Sigortası Genel Şartları

- Sağlık Sigortası Genel Şartları

- Seyahat Sigortası Genel Şartları

- Finansal Sigortalar

- Kefalet Sigortası Genel Şartları

- Bina Tamamlama Sigortası Genel Şartları

- Mal Sigortaları 
- Cam Kırılmasına Karşı Sigorta Genel Şartları

- Elektronik Cihaz Sigortaları Genel Şartları

- Emtia Nakliyat Sigortası Genel Şartları

- Hirsızlık Sigortası Genel Şartları

- İnşaat Sigortası (All Risk) Sigortası Genel Şartları

- Kara Araçları Kasko Sigortası Genel Şartları

- Kıymetli Nakliyat Poliçesi Umumi Şartları

- Makine Kırılması Sigortası Genel Şartları

- Montaj Sigortası Genel Şartları

- Seyahat Araç Destek Sigortası Genel Şartları

- Tekne Poliçesi Genel Şartları

- Yangına Bağlı Kar Kaybı Sigortası Genel Şartları

- Yangın Sigortası Genel Şartları

- Zorunlu Deprem Sigortası Genel Şartları (DASK)

- Kredi Sigortaları

- Borç Ödeme Sigortası Genel Şartları

- Kredi Sigortası Genel Şartları

- Tek Risk Sigortası Genel Şartları

- Sorumluluk Sigortaları

- Asansör Kazalarında Üçüncü Kişilere Karşı Sorumluluk Sigortası Genel Şartları

- Bağımsız Denetçilik Mesleki Sorumluluk Sigortası Genel Şartları

- Çevre Kirliliği Mali Sorumluluk Sigortası Genel Şartları

- Deniz Araçları Zorunlu Mali Sorumluluk Sigortası Genel Şartları

- Gayrımenkul Değerleme Mesleki Sorumluluk Sigortası Genel Şartları

- İşveren Sorumluluk Sigortası Genel Şartları 
- Karayolları Motorlu Araçlar Zorunlu Mali Sorumluluk Sigortası (Trafik Sigortası) Genel Şartları

- Kıyı Tesisleri Deniz Kirliliği Zorunlu Mali Sorumluluk Sigortası Genel Şartları

- $\quad$ Mesleki Sorumluluk Sigortası Genel Şartları

- Motorlu Kara Taşıtları İhtiyari Mali Sorumluluk Sigortası Genel Şartları

- $\quad$ Özel Güvenlik Zorunlu Mali Sorumluluk Sigortası Genel Şartları

- Tehlikeli Maddeler ve Tehlikeli Atık Zorunlu Mali Sorumluluk Sigortası Genel Şartları

- $\quad$ Tibbi Kötü Uygulamaya İlişkin Zorunlu Mali Sorumluluk Sigortası Genel Şartları

- Tüpgaz Zorunlu Sorumluluk Sigortası Genel Şartları

- Üçüncü Şahıslara Karşı Mali Mesuliyet Sigortası Genel Şartları

- UÜrün sorumluluk Sigortası Genel Şartları

- Zorunlu Sertifika Mali Sorumluluk Sigortası Genel Şartları

- Tarım Sigortaları

- Hukuksal Koruma Sigortası

Yukarıda bahsettiğimiz genel şartlara ilişkin inceleme neticesinde, getirilen düzenlemelerden bazı istisnalar dışında, norm dilinin TTK ve SigK'da olduğu gibi ayırımcı bir yapıdan uzak olduğu görülmektedir. Genel şartların çoğunda "sigortalı", "sigorta ettiren”, "lehtar", "hak sahibi", "hakem bilirkişiı", "sigortadan faydalanan kimse", “yolcu”, "kazazede”, “taşımacı", "acente”, "sürücü”, "hasta”, "borçlu”, “satıcı”, “tüketici”, “mirasç”, “müstahdem”, “imalatçı”, “işveren-işçi”, “eksper”, “aktüer”, temsilci”, "kirac1-kiralayan”, "malik”, "zilyed”, "intifa hakkı sahibi”, "kefil” vb. gibi ayrıştırıcı olmayan ifadelerin yer aldığı görülmektedir. Ancak tüm genel şartlarda bu yaklaşımın benimsendiğini söylememiz ne yazık ki mümkün değildir. Özellikle deniz ticareti hukuku ile ilintili ve bundan ötürü sigorta hukukuna bağ kurulan sigorta sözleşmelerinin genel şartlarında cinsiyet ayrımı oluşturan ifadelere rastlamak mümkündür. Açıklamamızı örneklemek gerekirse, Emtia Nakliyat Sigortası Genel Şartları m. $1^{117}$, m. $5^{118}$ düzenlemelerinde "gemi adamları", "sigortalının veyahut bunların adamlarının" gibi tercih ettiği ifadeler ayırımcı, cinsiyetçi bir dili ortaya koymaktadır.

117 M.1 "Sigortalı malların firtınadan, geminin batmasından veya karaya vurmak veyahut kaya veya siğhlğa bindirmek gibi haller neticesinde tamamen veya kısmen harap olmasından, oturmadan, çatışmadan, sabit, seyyar veya sabih bir cisme (buz dahil) çarpmasından, malın denize atılmasından, yangından, infilaktan, kaptan ve gemi adamlarının barataryasından yükleme, aktarma veya boşaltma ameliyeleri esnasında bir veya birden çok dengin düşmesinde ve genel olarak deniz kaza ve tehlikelerinden gelebilecek her türlü zıya veya hasarlar, bu poliçe ile tespit olunan şartlar dahilinde sigortacıya ait olacaktır". Genel Şartlar için bkz. <https://tsb.org.tr/media/attachments/Emtea_Nakliyat_Sigortası_Genel_Sartları.pdf> Erişim tarihi 10.07.2021.

118 M. 5(2) "Yasak veya gizli ticaret, kaçakçılık, emtianın ithal, ihraç veya transitine müteallik kanun ve nizamlara aykırılık, 
Benzer dil yapısını Tekne Sigortası Genel Şartlarında da görebilmemiz mümkün olmaktadır. Genel şartlarda kullanılan ifade yine, A. $4^{119}$ ve B.2 maddelerinde aynı olup, "gemi adamları” şeklindedir. Keza sorumluluk sigortası türlerinden biri olan deniz araçları zorunlu sorumluluk sigortası için hazırlanan Deniz Araçları Zorunlu Sorumluluk Sigortası Genel Şartları kapsamında teminat kapsamı dışında kalan hallerin düzenlendiği A.5.(b) ${ }^{120}$ maddesinde "gemi adamları" ifadesinin kullanıldığını görmekteyiz.

Genel şartlar bağlamında şu noktaya dikkat çekmekte fayda olduğunu düşünmekteyiz. Yukarıda saydığımız ve türlerine göre farklılıklar arz eden genel şartlar içerisinde özellikle Deniz Hukukunun alanına ilişkin düzenlemelerde, özellikle "adam/ları", "gemi adamları" gibi ifadelere yer verilmesiyle cinsiyetçi, ayrıştırıcı bir dilin benimsendiğini görmekteyiz. Bu kullanımın ana kaynağı ise, TTK kapsamında Deniz Ticareti hükümlerinde kullanılan ifade ve tanımlamalardır. Genel şartların, kanun dili ile örtüşen bir sistem benimsemesi isabetlidir. Ancak bu benimseme, çalışma konumuz kapsamında mevzuatta kullanılan dil açısından ayırımcı, cinsiyetçi bir yaklaşımın sair düzenlemelere de sirayet ettiğini göstermektedir. Öncelikle TTK kapsamında Deniz Ticareti Hukuku bölümünde yer alan ayırımcı ve cinsiyetçi ifadelerin terk edilmesi ve akabinde de bu iyileştirmenin sirayet eden düzenlemelere yansımasının sağlanması gerektiği kanısındayız. Çalışma kapsamında mukayeseli hukuk nazara alınarak bir değerlendirme yapılmamıştır ancak, mevzuatın dilinin seçimindeki özeni örneklemek bağlamında İngiltere’deki düzenlemeden bahsetmek uygun olacaktır. İngiltere'de 1906 tarihli Marine Insurance Act ${ }^{121}$ düzenlemesinin "gemi adamları" ifadesini tercih etmeyip, "gemi mürettebatı (crew member)" ve muadili ifadeleri kullandığı, ayırımcı bir söylemden kaçındı̆̆ görülmektedir. TTK'da yapılan son güncellemenin 2011 yılında olduğunu nazara aldığımızda, ayırımcı ve cinsiyetçi ifadenin kanun metnine dahil edilmesi eleştiri konusu teşkil etmektedir. Kanunun tercih ettiği "gemi adamları" ifadesi yerine "gemi çalışanı" ya da "gemi insanı" ifadeleri daha isabetli olabilirdi ${ }^{122}$.

hakikat hilafi beyan, sigorta akdinin veya sigortalınn veyahut bunların adamlarınin vekil veya mümessillerinin fil veya kusurları" (5) "Sigorta akidi nakliyatı bizzat yaptığı veya adamlarına yaptırdığ takdirde, kaptanın ve gemi adamlarının barataryasından, hile ve hud'asından, ihmalinden, ihtiyatsızhğından, ehliyetsizliğinden ileri gelen zıya ve hasarlar sigortaya dahil değildir." Genel Şartlar için bkz. <https://tsb.org.tr/media/attachments/Emtea_Nakliyat_Sigortası_Genel_Sartları. pdf $>$ Erişim tarihi 10.07.2021.

119 M. A.4. "Taraflar bașka bir esas kararlaștırmamıșlarsa, gemi veya diğer deniz ve göl araçlarının sigorta değeri, rizikonun bașladığı andaki değeridir. Aksi kararlastırılmadıkç yakıt, kumanya ve levazım, gemi adamlarının ücretleri, sigorta ücreti bu değere dahil değildir". M. B.2. "Sigorta ettiren veya sigortadan haberi olması halinde sigortal, rizikonun gerçekleștiğini öğrenir öğrenmez bu durumu sigortaciya bildirmekle yükümlüdür. Sigorta sözleșmesinden doğan borcun muaccel olabilmesi için sigortal, tazminatın hesabın gösteren bir liste ile diğer gerekli belgeleri vermek zorundadır. Bu belgeler özellikle sunlardır: Deniz raporu, ...gemi adamları donatımında asgari emniyet belgesi, gemi adamları listesi..." Genel Sartlar için bkz. <https://tsb.org.tr/media/attachments/Tekne_Policesi_Genel_Sartları.pdf $>$ Erișim tarihi 10.07.2021.

120 M. A.5.(b) "Gemi adamları, sigortalının eylemlerinden sorumlu tutulduğu diğer kişiler ile yolcu bileti olmaya (kaçak olarak seyahat eden) kişilerin talepleri” Genel Şartlar için bkz. <https://tsb.org.tr/media/attachments/Deniz_Aracları_ Zorunlu_Mali_Sorumluluk_Sigortası_Genel_Sartları.pdf $>$ Erişim tarihi 10.07.2021.

$121<$ https://www.legislation.gov.uk/ukpga/Edw7/6/41/contents> Erişim tarihi 10.07.2021.

122 Gemi adamı, en basit tanımlama ile denizde çalışan işçi olarak adlandırılmaktadır. Bu tanımlama dışında çeşitli mevzuatlarda gemi adamlarına ilişkin tanımlamalara rastlamak mümkündür. Deniz İş Kanunu m. 2/b "bir hizmet akdine dayanarak gemide çalışan kaptan, zabit ve tayfalarla diğer kimselere geni adamı denir" şeklinde tanımlama getirmiştir. Gemi Adamları Yönetmeliği m. 4/32 "geminin kaptanın, zabitlerini, yardımcı zabitlerini, stajyerlerini, tayfaların ve yardımo ıizmet personelini...ifade eder" şeklindedir. Burada dikkat çeken husus, tanımı yapılan kavramın tanımının 


\section{YARGITAY KARARLARI VE SIGORTA HAKEM HEYETLERININ KARARLARINDA KULLANILAN DIL BAKIMINDAN GENEL DEĞERLENDIRME}

\section{a. Yargıtay Kararlarında}

Sigorta uyuşmazlıklarında Yargıtay’ın vermiş olduğu sayısız karar bulunmaktadır. Bu kararlar içerisinde Yargıtay'ın kaleme aldığı gerekçelendirmelerde cinsiyetçi ya da ayırımcı bir dili tercih ettiğini söylememiz mümkün değildir. Meğerki, mevzuatın kullandığı dil ayırımcı, cinsiyetçi bir söylemi benimsemiş olsun. Yargıtay kararlarına konu olan somut olayın çözümü açısından kullanılan kanun, yönetmelik, genel şartlar, özel şartlar vb. kapsamında şayet ayırımcı bir dil tercih edilmişse, bu söylemin Yargıtay kararında referans olarak alınması ister istemez karar içerisinde ayırımcı bir söylemin bulunmasına neden olacaktır. Çalışmamızın önceki başlıklarında da ele aldığımız üzere, "gemi adamı” söylemi kapsamında Yargıtay’ı çok sayıda kararı bulunmaktadır ${ }^{123}$. Bu kararların kaynağını yasal düzenlemeler, genel ya da özel şartlar teşkil etmektedir.

\section{b. Sigorta Hakem Heyeti Kararlarında}

Sigorta hakem heyetinin fonksiyonu sigorta uyuşmazlıklarında oldukça önemli bir yer teşkil etmektedir. Gerek hızlı süreç gerek verdiği kararlar, sigorta şirketi ile uyuşmazlığa düşen sigorta ettiren, sigortalı ve hak sahipleri açısından tercih edilen bir yol olarak karşımıza çıkmaktadır. Tercih edilen hakem uyuşmazlık çözüm yönteminin vermiş olduğu kararların ve bu kararlarda kullandığ 1 dilin, söylemin önemi çalışmamız açısından yadsınamayacaktır.

Hakem kararlarına yönelik olarak yaptı̆̆ımız incelemelerde, kullanılan dil açısından ayırımcı, cinsiyete dayandırılan bir yöntemin olmadığını söylemek mümkündür. Hakem kararlarında da genellikle TTK hükümleri, genel şartlar ve özel şartlara ilişkin düzenlemeler referans olarak alındığından, bu düzenlemelerdeki söylemler kendiliğinden karar metinleri içerisinde de yer almaktadır. Nitekim çalışmamızın 1.3 başlığında dile getirdiğimiz üzere, genel şartların bir kısmında kullanılan ifadelerdeki ayırımcı söylem, somut olayda ilgili genel şart hükümlerine atıf yapılması halinde, ister istemez hakem karar metinlerine de sirayet etmektedir. Örneğin K. 20.04.2021 Tarih, 47765 sayılı $^{124}$ nakliyat sigortası konulu hakem kararında, Emtia Nakliyat Sigortası Genel Şartlarının m. 1 hükmüne atıf yapılması ve bu madde içerisinde "gemi adamları" ifadesinin geçmesi, hakem kararının kendiliğinden ayırımcı bir dile bürünmesine sebep olmaktadır.

\footnotetext{
içerisinde cinsiyetçi bir dil olmamasına karşın tanımlanan kavramın bizzat cinsiyetçi, ayırımcı olmasıdır.

123 Yargitay 21 HD. E 2016/10366, K. 2018/1973, T. 1.3.2018; Yargitay 21 HD., E. 2016/17545 K., 2018/1389, T. 19.02.2018; Yargitay 3 HD., E. 2020/8336, K. 2020/5548, T. 7.10.2020. Karar metinleri için bkz. <www.lexpera.com.tr>.

124 <http://www.sigortatahkim.org/files/karardrgs46.pdf> Erişim tarihi 12.07.2021.
} 


\section{3. uYGULAMAYA (SIGORTA SEKTÖRÜNE) KADIN-ERKEK EŞITLIĞININ NE DERECE YANSIDIĞI SORUNU}

Yasal düzenlemelerin, karar mercilerinin sigorta hukukuna dair kullandıkları dile ilişkin kısaca bilgi paylaşımının ardından, ayırımcı bir uygulamanın sigorta sektöründe olup olmadı̆̆ının da ele alınmasında fayda olduğunu düşünmekteyiz. O nedenledir ki, sigorta sektöründe bir ayırımcılığın söz konusu olup olmadığına da kısaca değinmek bu çalışma kapsamında hasıl olmaktadır.

Sigorta sektörü, Türkiye'de bankacılık sektöründen sonra ikinci sırada yer alan finansal aktörlerdendir. Bankacılık sektörü kadar gelişim gösteremese de - daha doğrusu bankacılık sektörü ile arasındaki makas büyük olsa da - finansal açıdan önemli bir sektör olduğu tartışmasızdır. Ülke ekonomisine sağladığı katkı, yarattığı istihdam, vb. sigortacılık sektörünün faydalarından birkaçıdır. Finans sektörünün böylesi önem arz eden aktörlerinden biri olan sigortacılık sektöründe kadın-erkek eşitliği, toplumsal cinsiyet bilincinin ne düzeyde olduğu belirlemek yerinde olacaktır.

Tablo I: Sigorta sektöründe istihdam verileri (3I.12.2020)

\begin{tabular}{|c|c|c|c|}
\hline Mezun Olduğu Eğitim Kurumu & Erkek & Kadın & Toplam \\
\hline Ikokul & 68 & 38 & 106 \\
\hline Drtaokul ve Dengi & 61 & 14 & 75 \\
\hline ise ve Dengi & 650 & 514 & 1.164 \\
\hline 2 Yıllık Yüksekokul & 610 & 998 & 1.608 \\
\hline Ĵniversite & 4.513 & 5.044 & 9.557 \\
\hline isansüstü & 1.007 & 911 & 1.918 \\
\hline IOPLAM & 6.909 & 7.519 & 14.428 \\
\hline
\end{tabular}

Kaynak: Türkiye Sigorta Birliği İstatistikleri

https://www.tsb.org.tr/tr/istatistikler (erişim tarihi 23.07.2021)

Türkiye'de hali hazırda sigorta sektöründe faaliyet gösteren (sigorta şirketi, reasürans vb.) 62 adet şirket bulunmaktadır. Tablodaki güncel veriler ışığında, Türkiye’de sigortacılık sektöründe toplam istihdam sayısı 14.428 kişi olup, bunun 7.519’u kadın 6.909’unu erkekler oluşturmaktadır. Bu veriler kapsamında sigorta sektöründe hali hazırda kadın istihdam sayısının erkek istihdamından fazla olduğunu söylememiz mümkündür. Keza tablo incelendiğinde istihdam edilen çalışanların eğitim düzeyleri bakımından da kadın çalışanların özellikle yüksekokul ve lisans eğitimi branşlarında önde olduğunu görmek mümkündür.

Tablodaki veriler bir an için kadın istihdamının erkek istihdamına göre fazla olması nedeniyle kadın ağırlıklı bir yapının olduğu olumlu bir görsel olarak görülse de, bu durum beraberinde şöyle bir tezat (oxymoron) durum yaratmaktadır. Bu denli kadın ağırlıklı bir yapıda kadınlar gerçekten sigorta sektöründe erkekler kadar kolay yer bulabilmekte midir? Kariyerleri önünde engel/ler var mıdır? Asıl sorulması gereken sorunun bu olduğunu kanısındayız. İstihdam verilerinin yansıttığı bu rakamlar tek başına, yönelttiğimiz sorulara "evet” diyebilmemiz için yeterli değildir. 
Towers Watson ${ }^{125} 2015$ yılında hazırlamış olduğu bir raporunda sigorta sektöründe kadın yönetici oranın \%37 oranında olduğunu belirtmiştir. Dünya genelinde sigorta sektörü alanında \%55’lik istihdam oranına sahip olan kadınların, yönetimde aldıkları rol oranı \%37 olarak belirlenmiştir. Bu veriler nazara alındığında sigorta sektöründe dünya genelinde şirketlerin kadın istihdam etmedeki başarısını, kadın yönetici çıkarma noktasında gösteremediğini gözler önüne sermektedir. Sektör açısından yapılan incelemelerde de sigortacılık sektörünün en fazla kadın istihdam eden sektör olmasına karşın yöneticilik seviyesine kadınların ulaşmasında dördüncü sırada yer aldığı mevcut verilerle tespit edilmiştirir26. Dolayısıyla sektör istihdamdaki başarısını, kadınların yönetimde aldıkları rol bakımından sürdürememektedir.

Tower Watson'ın sigorta sektöründe kadınların yönetimde aldıkları rol açısından Türkiye özelinde yaptığı değerlendirmesinde, kadınların yöneticilik seviyesine ulaşmada başarılı olduğundan bahsetmektedir ${ }^{127}$.

\section{4. ÖNERILER}

Mevzuat, ikincil düzenlemeler, hakem ve yargı kararları çerçevesinde genel bağlamda sigorta hukuku özelinde ayrıştırıcı bir dil benimsendiğinden bahsetmemiz mümkün değildir. Ancak yasa düzenlemelerinde yer alan bazı ifadeler, ikincil düzenlemelerde kullanılan kelimeler sigorta hukuku özelinde ayrıştırıcı tanımlamaların, ifadelerin mevcudiyetine sebebiyet vermektedir. Bu ifadeler mevzuat düzenlemelerinin içerisinde yer aldıkları için gerek teoride gerek pratikte karşımıza çıkmaktadır. Bunu önlemek adına ilgili düzenlemelerde revizyona gidilmeli ve yapılan mevzuat güncellemelerinin mevzuat ile ilintili olan tüm düzenlemelere sirayeti sağlanmalı ve bu konuda yeknesaklık oluşturulmalıdır.

Sigorta sektörü açısından istihdam konusunda kadın çalışan oranının erkek çalışan oranına göre fazla olduğu, ancak bu realitenin kadınların yöneticilik kademesindeki oranına aynı şekilde yansımadığı görülmektedir. Sektörde kadın çalışan ağırlıkta olmasına karşın, bu olumlu gelişimi sigorta sektörünün kadın yönetici çıkartma noktasında görememekteyiz. Sigorta sektöründe yöneticilik statüsünde kadın çalışan sayısının artması noktasında ve keza fırsat eşitliğinin önündeki engellerin gerekli çalışma ve regülasyonlar ile düzenlenmesi, düzenlenmesi ve böylelikle kadın çalışanların önlerindeki bariyerlerin bertaraf edilmesi gerektiği kanısındayız.

125 Wills Towers Watson, İngiliz menşeili, çok uluslu sigorta danışmanlığı, aracılığı hizmeti veren, sigorta sektörü alanında faaliyet gösteren köklü bir şirkettir. Ayrıntı için bkz. <https://www.willistowerswatson.com/tr-TR/About-Us/overview> Erişim tarihi 12.07.2021.

126 Rapor hakkında ayrıntılı bilgi için bkz. <https://www.sigortix.com/haberdetay-HaberID-132-Haber-en-yuksek-kadinistihdam-orani-yuzde-55-ile-sigorta-sektorunde.html $>$ Erişim tarihi 15.07.2021.

$127<$ https:/www.sigortix.com/haberdetay-HaberID-132-Haber-en-yuksek-kadin-istihdam-orani-yuzde-55-ile-sigortasektorunde.html> Erişim tarihi 20.10.2021. 


\section{E. ULUSLARARASI INSAN HAKLARI HUKUKU}

Hukuk fakültelerinde okutulan diğer derslerle karşılaştırıldığında, insan hakları hukuku dersinin doğası gereği toplumsal cinsiyet eşitliği temelinde yürütüldüğü, eşitlik ilkesi ve ayırımcılık yasağı gibi temel ilkelere dayanan bu alanın ayırımcı ve cinsiyetçi bir yaklaşımdan azade olduğu düşünülebilir. Ancak alana ilişkin teorik tartş̧malar, hukukun diğer alanları gibi insan hakları hukukunun da cinsiyetçi ve cinsiyet körü olabildiğini göstermiş ${ }^{128}$; uluslararası normlar, ilkeler, mahkeme kararlarının gerekçeleri ve uygulama, eleştirel bir bakış açısıyla ele alınmıştır. Bu alt başlıkta, insan hakları hukukunun feminist teori çerçevesinde geçirdiği dönüşüm, birkaç ana hat üzerinden ele alınmaktadır.

İnsan hakları bir fikir ve kavram olarak eskiye uzanır ancak uluslararası hukukun bir konusu olması görece yakın tarihlidir. Geleneksel anlamda uluslararası hukuk egemen devletler arasındaki ilişkileri düzenlediği için, II. Dünya Savaşı’na kadar devlet-yurttaş ilişkileri ya da yurttaşlar arasındaki ilişkiler genel olarak bu disiplinin konusu olmamıştır ${ }^{129}$.

İnsan hakları hukuku, asıl olarak devletler hukuku olarak görülen uluslararası hukukun içinde gelişmekle birlikte, kişiler arasındaki ilişkiler de bu alanın konusudur. Kişiler arasında gerçekleşen insan hakları ihlallerinde sorumluluk çoğu durumda devletin üzerindedir. Bununla birlikte bu yaklaşım da zamanla değişmiş ve hem gerçek kişiler hem de özel hukuk tüzel kişileri uluslarararası hukukun öznesi haline gelmişlerdir. 20. yüzyılın ikinci yarısında gelişen uluslararası insan hakları hukuku, bireyi doğrudan uluslararası hukukun öznelerinden biri haline getirmek açısından devrimsel rol oynamıştır. Ancak bu alanın kendisi de feminist eleştirilerden payını almış ve dönüşmek zorunda kalmıştır. Dolayısıyla, hukuk fakültelerinde anlatılan bir insan hakları hukuku dersinin bu bakış açısını es geçmesi, hem normatif yapıdaki hem de uygulamadaki cinsiyetçi veya cinsiyet körü yaklaşımı dikkate almamış olur. Böyle bir yaklaşım, eşitlik ilkesi ve ayırımcılık yasağının günümüzde ulaştı̆̆ kapsamı yansıtmakta, şiddet ve istismarın farklı türlerini ve toplumsal cinsiyete dayalı temellerini görmekte yetersiz kalır ve hatalı çıkarımlara zemin hazırlar.

Feminist çalışmaların uluslararası insan hakları hukukuna yönelttiği eleştiriler geniş bir literatür ortaya çıkarmıştır. Oldukça zengin ve çok boyutlu olan bu tartışmaları tamamıyla kapsamak mümkün olmamakla birlikte, eleştirilerin yoğunlaşttğı ve insan hakları hukukunu dönüştüren birkaç ana hat belirlenebilir.

Feminist çalışmaların uluslararası hukuka yönelttikleri temel eleştiri, hem normların oluşturulmasına ilişkin yapının hem de normların içeriğinin erkeklerin önceliklerini yansıttığı ve uluslararası hukukun cinsiyetli bir sistem olduğudur ${ }^{130}$. Bununla bağlantılı şekilde, insan haklarının aslında erkeklerin hakları olarak kurgulanmış olduğu belirtilmiştir. Uluslararası hukuk düzeninin yasa

128 Charlotte Bunch, 'Transforming Human Rights from a Feminist Perspective' iç Julie Peters and Andrea Wolper (eds) Women's Rigths, Human Rights: International Feminist Perspectives (Routledge 1995).

129 Manfred Nowak, International Human Rights Regime (Martinus Nijhoff Publishers 2003) 16-22.

130 Hilary Charlesworth, Christine Chinkin and Shelly Wright, 'Feminist Approaches to International Law' (1991) 85(4) The American Journal of International Law 613, 615. 
yapıcı organlarında erkeklerin baskın olması nedeniyle, uluslararası insan hakları hukukunun erkeklerin deneyimlerini yansıtacak ve kadınların deneyimlerini dişlayacak şekilde oluşturulduğu, bunun da insan hakları hukukunun nesnel ve evrensel olma iddiasının altını oyduğu belirtilmiştir ${ }^{131}$. Uluslararası kurumların yapısına bakıldığında karar alma mekanizmalarında erkeklerin, görece ikincil görevlerde ise kadınların yer aldığı görülmektedir. Bu durumun uluslararası hukukun normatif yapısına da yansıdı̆̆ı ve normların oluşturulmasında yine ataerkil bakış açısının temel alındığı belirtilmektedir ${ }^{132}$.

$\mathrm{Bu}$ yansımanın başlıca örneklerinden biri olarak temel hakların sinıflandırılmasında esas alınan yaklaşıma bakılabilir. İnsan hakları hukukunda öncelik genellikle birinci kuşak haklar denilen medeni ve siyasal haklara verilmiş, ikinci kuşak haklar denilen ekonomik, sosyal ve kültürel haklar ise uzun süre aynı ilgiyi görmemiştir ${ }^{133}$. Feminist teorisyenler ikinci kuşakta yer alan ve ikincilleşen bu hakların kadınların gündelik hayatı açısından büyük önem taşıdığına dikkat çeker. Örneğin beslenme, barınma, eğitim, sağlık vb. hakların kullanılması söz konusu olduğunda, devletin gerçekleştirmediği ya da ihmal ettiği yükümlülükler çoğunlukla hane içindeki kadınlarca gerçekleştirilir. Evdeki çocuğun, yaşıının, hastanın, engellinin bakım ve ihtiyaçlarının giderilmesi, evdeki kadınlardan ve kimi zaman da kız çocuklarından beklenir.

Öte yandan bu hakların düzenlenme şekli, kamusal alan ve özel alan arasındaki klasik ve insan hakları hukukuna temel alınan yaklaşımı yansıtır. Örneğin BM Ekonomik, Sosyal ve Kültürel Haklar Sözleşmesi’nin çalışma hakkına ilişsin maddesi çalışmayı kamusal alanda gerçekleşen bir faaliyet olarak dikkate alır ve böylece kadının ev içi emeğinin ekonomik değeri görünmez olur ${ }^{134}$. Yani toplumsal cinsiyet perspektifinden yoksun olan insan hakları hukuku normları bu emeği dikkate almamıştır. Dolayısıyla mevcut normların, kadınların gündelik yaşam deneyimlerini dikkate alarak yorumlanması ve uygulamaya geçirilmesi gerekliliği ortaya çıkar. Çalışma hakkı, sosyal güvenlik hakkı, beslenme hakkı, barınma hakkı gibi hakların birer temel hak olarak tam anlamıla güvence altına alındığından söz edebilmek için, hem kadının görünmeyen emeğini, hem de ev yaşamında ve profesyonel yaşamda kadın ve erkek arasındaki eşitsiz iş yükü dağılımını dikkate almak bir gerekliliktir.

Bu tartışmalarla bağlantılı olarak tartışmaya açılan ikinci konu, kamusal alan ve özel alan arasında esas alınan yaklaşımın insan hakları hukukundaki yansımasıdır. İnsan hakları hukuku, gelişiminin belirli bir aşamasına kadar toplumsal cinsiyetle ilişkili sorunlara yanıt vermemiştir. Uluslararası hukuk düzeni, liberal düşünce temelinde, birbiriyle eşit, özgür ve birbirinden bağımsız devletlerin sosyal sözleşme ile bir araya gelerek oluşturdukları bir düzen olarak kabul edilmiştir ${ }^{135}$. Uluslararası

131 Hilary Charlesworth, 'Human Rights as Men's Rights' iç Julie Peters and Andrea Wolper (eds) Women's Rigths, Human Rights: International Feminist Perspectives (Routledge 1995) 103.

132 ibid 104-105.

133 Uluslararası insan hakları hukukuna yönelik feminist eleştiriler ve bu bağlamda sosyal hakların ikincilleşmesi ile kadın deneyimlerinin görünmez kılınması arasındaki ilişki hakkında bkz. Özge Yücel Dericiler, Sosyal Haklar ve İnsan Hakları Hukukunda Devletin Yükümlülükleri: Refah Devletinin Krizi Ekseninde Bir İnceleme (On İki Levha 2014) 302-320.

134 Charlesworth (n 131) 108.

135 Celine Romany, 'Women as Aliens: A Feminist Critique of the Public/Private Distinction in International Human Rights 
hukukun esasen devletler arasındaki ilişkileri düzenleyen ve devlet odaklı gelişimi, devlet tarafından gerçekleştirilen insan hakları ihlallerini öne çıkarmıştır. Bu da özel kişiler tarafından veya özel alanda gerçekleşen ihlallerin insan hakkı ihlali olarak görülmemesi sonucunu doğurmuştur ${ }^{136}$. Temel hak kategorileri içinde medeni ve siyasal hakların -yukarıda belirtildiği üzere- ön plana çıkması ve söz konusu hak kategorisinin dayandığı liberal ideolojinin özel alandan devlet müdahalesini uzak tutma çabası, hem özel alanda gerçekleşen ihlallerin dikkate alınmamasina neden olmuş, hem de özel kişiler ve gruplar tarafından gerçekleştirilse dahi söz konusu ihlallerde devletin sorumluluğunu tartışmaya imkân vermemiştir. Yine bu yaklaşım dolayısıyla, aile hayatının korunması için aile içinde gerçekleşen ihlallere devletin müdahale etmemesi gerektiği kabul edilmiştir ${ }^{137}$. Oysa kadınların yaşadıkları hak ihlalleri sadece medeni ve siyasal haklarıyla sınırlı değildir ve sadece kamu gücü kullanan kişilerce gerçekleştirilmemektedir. Bu gerçekten hareketle, örneğin CEDAW'da ayırımcılık "kadınların, medeni durumlarına bakılmaksızın ve kadın ile erkek eşitliğine dayalı olarak siyasal, ekonomik, sosyal, kütlürel, medeni veya diğer sahalardaki insan hakları ve temel özgürlüklerinin tanınmasını, kullanılmasını ve bunlardan yararlanılmasını engelleyen veya ortadan kaldıran veya bunu amaçlayan ve cinsiyete bağlı olarak yapılan herhangi bir ayrım, mahrumiyet veya ksıtılama" (m. 1) olarak tanımlanmıştır.

Yeri gelmişken, kadının insan hakları açısından başı çeken belgelerden biri olan CEDAW’ın dahi feminist eleştirilerden pay aldığını da belirtmek gerekir. Temel haklara ilişkin sözleşmelerin cinsiyetsiz/cinsiyet körü olması ve kadınlara yönelik ayırımcılık ve şiddet gibi sorunların yanıtsız kalması, ikiz sözleşmelerden ${ }^{138}$ ayrı bir sözleşme daha kabul etmenin gerekçesi olmuş ve CEDAW’a zemin hazırlamıștır ${ }^{139}$. Kadın hareketinin ve feminist aktivistlerin odaklandıkları temel konu kadınların erkeklerle eşit haklara sahip kılınması olmuş ve 1979 yılında kabul edilen CEDAW kadınların erkeklerle aynı haklara sahip kılınmasını güvence altına almıştır. Diğer yandan Sözleşme’nin cinsiyetler açısından tarafsız (gender-neutral) hükümlerinin, kadınlar ve erkekler arasındaki yapısal eşitsizliği dikkate almakta yetersiz kaldığı eleştirisi getirilmiştir ${ }^{140}$.

Feminist bakış açısı çerçevesinde hem özel ve kamusal olarak nitelendirilen sorunlara ilişkin yaklaşım gözden geçirilmiş, hem de kadına yönelik şiddetle mücadelede devletin yükümlülükleri yeniden tanımlanmıştır ${ }^{141}$. Dolayısıyla üçüncü ana hat olarak, kadına yönelik toplumsal cinsiyete dayalı şiddet kavramının ve devletin bu şiddeti önlemeye yönelik yükümlülüklerinin feminist teorisyenlerin ve aktivistlerin çabasıyla geçirdiği dönüşüm belirlenebilir.

Law' (1993) 6 Harvard Human Rights Journal 87, 89.

136 Donna Sullivan, 'The Public/Private Distinction in International Human Rights Law' in Julia Peters ve Andrea Wolper (eds), Women's Rights, Human Rights: International Feminist Perspective (Routledge 1995) 126-127.

137 ibid 127.

138 İkiz sözleşmeler ile BM Medeni ve Siyasal Hakları Sözleşmesi ile BM Ekonomik, Sosyal, Kültürel Haklar Sözleşmesi kastedilir.

139 Natalie Hevener Kaufman ve Stefanie A. Lindquist, 'Critiquing Gender-Neutral Treaty Language: The Convention on the Elimination of All Forms of Discrimination against Women' in Julia Peters ve Andrea Wolper (eds), Women's Rights, Human Rights: International Feminist Perspective (Routledge 1995), 114-125.

140 bid 118-119.

141 Yakın Ertürk, Sınır Tanımayan Şiddet: Paradigma, Politika ve Pratikteki Yönleriyle Kadına Şiddet Olgusu, (Metis 2015$) 64$. 
Feminist bakış açısından ele alındığında, şiddetin hem farklı türleri hem de toplumsal cinsiyete dayalı temelleri vurgulanır. Kadına karşı/yönelik şiddet konusu 1980’lerden itibaren kadının insan hakları bağlamında tartışılan temel konularından biri olmuş ve 90’lı yıllardan itibaren uluslararası sözleşmelerde düzenlenmeye başlamıştır. 1993 tarihli BM Kadınlara Yönelik Şiddetin Ortadan Kaldırılmasına Dair Bildirge’de kadına yönelik şiddetin “erkeklerin kadınların üzerinde egemenlik kurmalarına ve onlara karşı ayrımcılık yapmalarına ve kadınların azami derecede ilerlemelerine engel olmasına yol açan, kadınlar ve erkekler arasındaki tarihten gelen eşit olmayan güç ilişkisinin bir tezahürü olduğunu ve kadınlara yönelik şiddetin, kadınları erkeklerle karşılaştırıldığında ikincil konuma zorlayan can alıcı sosyal mekanizmalardan biri olduğu” kabul edilmiştir. CEDAW Komitesi'nin 12, 19 ve 35 no'lu tavsiye kararları ${ }^{142}$ da şiddetin toplumsal cinsiyete dayalı kökenlerini dikkate alarak farklı şiddet biçimlerini düzenlemiş ve şiddet konusunda devletlere pek çok yükümlülük yüklemiştir. Benzer şekilde İstanbul Sözleşmesi kadına karşı şiddetin kadına karşı insan hakları ihlali ve ayırımcılık biçimi olduğunu belirtmiş ve şiddet kavramını "ister kamu ister özel yaşamda meydana gelsinler, söz konusu eylemlerde bulunma tehdidi, zorlama veya özgürlüğ̈̈n rastgele bir biçimde kısıtlanması da dâhil olmak üzere, kadınlara fiziksel, cinsel psikolojik veya ekonomik zarar ve acı verilmesi sonucunu doğuracak toplumsal cinsiyete dayalı tüm şiddet eylemleri” olarak tanımlamıştır (m. 3-a).

Görüldüğü üzere, kamusal ve özel alan ayrımına ilişkin geleneksel yaklaşımın değişmesinde ve buna bağlı olarak devletin ihlallere ilişkin yükümlülüklerinin tespit edilmesinde, insan hakları hukukunu feminist perspektifle ele almak önemli bir rol oynamıştır. BM Kadına Karşı Şiddet Özel Raportörlüğü de yapmış olan Ertük'ün ifadesiyle:

"Küresel kadın hareketi, kabul görmüş insan hakları dilini, kadınların bu görünmeyen hak ihlallerini görünür kılacak biçimde yeniden tanımlayarak özel alanı ve cinsiyet açısından "nötr" gibi algılanan anaakım insan hakları hukukunu tartışmaya açmış, "evrenselliğin", "hak" ve "hukuk"un sınırlarını genişletmiştir. Örneğin bekâret kontrolünün bir terör eylemi, anne karnında kız fetüsün yok edilmesinin bir soykırım, dayak/eve hapsetme/ kadın sünneti/ tecavüz gibi eylemlerin ise kamu alanında bir suç teşkil eden işkenceyle eş anlamlı olduklarını göstermiştir" 143 .

Şiddet olgusunun bu kapsamda ele alınması ile, insan hakları ihlallerinde devletin yapması gerekenlere ilişkin tartışma da yeni bir boyut kazanmaya başlamıştır. Uluslararası düzeyde bakıldığında BM Kadınlara Yönelik Şiddetin Ortadan Kaldırılması Bildirgesi’nden bu yana devletlerin kadına karşı şiddet eylemelerini önlemek, soruşturmak ve failleri ulusal yasalara uygun biçimde cezalandırmak için gereken özeni gösterme yükümlülükleri vardır (4-c m). Yine de devletlerin kadına yönelik şiddetle mücadeleye ilişkin yükümlülükleri söz konusu olduğunda, uygulamada genellikle şiddet eylemi gerçekleştikten sonra yapılması gerekenlere odaklanıldığı görülmüştür. Feminist perspektiften özen yülkümlülüğü standardı ise, şiddeti gerçekleşmeden önleme, yani şiddeti ortaya çıaran ve sürdüren geleneksel/

142 CEDAW Komitesi'nin tavsiye kararları için bkz. <https://www.ohchr.org/EN/HRBodies/CEDAW/Pages/ Recommendations.aspx> Erişim Tarihi 09.09.2021.

143 Ertürk (n 141) 64. 
cinsiyetçi yapıyı dönüştürme anlamında daha kapsayıcı bir yükümlülüğü öne çıkarır. Aynı zamanda devlet dışındaki aktörlerin şiddete ilişkin sorumluluklarını da tartışmaya dâhil eder ${ }^{144}$. Örneğin İstanbul Sözleşmesỉnde kadına yönelik şiddeti önleme yükümlülüğüne ilişkin düzenlemeler bulunur (m. 12-17). $\mathrm{Bu}$ yükümlülük her şeyden önce devletlerin "kadınlarm daha aşağı düzeyde olduğu düşüncesine veya kadinlarm ve erkeklerin toplumsal olarak klişeleşmiş rollerine dayal ön yargıların, törelerin, geleneklerin ve diğer uygulamalarm kökünün kazınması amacıyla kadınların ve erkeklerin sosyal ve kültürel davranış kalplarının değiştirilmesine yardımcı olacak tedbirleri” almalarını gerektirir (m. 12).

Toparlamak gerekirse, hangi hakların temel hak olarak görüldüğü, özel ve kamusalın nasıl ele alınacağı, hangi aktörlerin ne tür eylemlerinin ihlal sayılacağı, devletlerin hangi eylemlere müdahale etmesi ve hangilerine etmemesi gerektiği, şiddetin ne olduğu ve ne şekillerde gerçekleşebildiği, şiddetin nasıl ortadan kaldırılabileceği başta olmak üzere, insan hakları hukukunun pek çok konu başlığı, toplumsal cinsiyet perspektifiyle ele alındığında yeni bir içerik kazanmıştır. Dolayısıyla insan hakları hukukunun tüm bu tartışmalardan bağımsız bir şekilde ele alınması, her şeyden önce evrensel insan hakları fikrinin içini boşaltır ve ihlallerin büyük bölümünü gözden kaçırmaya neden olur.

\section{SONUÇ}

Birleşmiş Milletler tarafından 2030 yllına kadar devletlere yerine getirmeleri gereken ödev ve sorumluluklar olarak yüklenen 17 hedeften biri olan ve hemen hemen tüm diğer hedeflerle ilişkisi bulunan toplumsal cinsiyete dayalı ve duyarlı bir sistemin benimsenerek yerleştirilmesi esası, gerçekte birbirine saygıll, adil yaşam koşullarında eşit paylaşım temeline dayanan bir dünyada, ayırımcılık ve nefret duygularının ortadan kaldırılarak sürdürülebilecek bir yaşamın bir ütopya değil gerçeklik olabileceği öngörüsüne dayanmaktadır.

Toplumsal cinsiyet eşitliğinin sağlanması ve insana sırf insan olması nedeniyle saygı duyulması, toplumsal yapıların insan hakları temelinde inşasını sağlarken, aslında manen de insanların mutluluğunu gerçekleştirecektir. Sahip olunan farklılıkların aslında bir zenginlik olarak ve olduğu gibi kabulü, sonuçta özgüveni tam, kendine ve çevresine saygılı ve en önemlisi mutlu bireylerin varlığına ve daha büyük pencereden baktığımızda mutlu toplumların oluşumuna olanak sağlayacaktır.

Tüm bu ideallerin gerçekleşmesi ise toplumsal cinsiyet eşitliği kavramının ve kavramın birçok alandaki görünüm biçimlerinin eğitime entegre edilmesini ve küçük yaşlardan itibaren insanlara anlatılmasını gerekli kılar. Özellikle hukuk eğitimi, kullanılan araçlarda yer verilen dil, anlatım, ifade, mevzuat ve uygulamanın dili oldukça önemli bir yer tutmaktadır. Bu nedenle, tüm mevzuatın, eğitim materyallerinin, öğretim ile uğraşanların, yazanların ve tabi uygulayıcıların toplumsal eşitlik kavramına azami özeni göstermesi ve hassasiyetle konuya yaklaşması önemlidir. Amaca ulaşmak zaman alacak olsa da başlamak önemlidir.

144 ibid 91-103; Fatma İrem Çağlar Gürgey, Özge Yücel Dericiler, 'Uluslararası İnsan Hakları Hukukunda Özen Yükümlülüğünün Dönüşümünün Bir Örneği Olarak CEDAW Komitesi’nin 35 Sayılı Tavsiye Kararı’ (2019) 1 Ankara Barosu Dergisi 231-266. 


\section{KAYNAKÇA}

Abik Y, Kadının Soyadı ve Buna Bağh Olarak Çocuğun Soyadı (Seçkin 2005).

Akın M Y ve Yağmur S, 'Türk Anonim Şirketler Hukukunda Eşit İşlem İlkesinin Uygulanması Açısından Objektif Kriter Kavramı’ (2018) 13(144) Terazi Aylık Hukuk Dergisi 96-105.

Aksakal H, "Yargıtay Kararlarında Toplumsal Cinsiyet Eşitsizliği: "Erkekler Lehine İşleyen Haksız Tahrik Kurumu'”, (2018), 1, Suç ve Ceza, Ceza Hukuku Dergisi, 25-46.

Arkan S, Ticari İşletme Hukuku (24. Baskı, Banka ve Ticaret Hukuku Araştırma Enstitüsü 2018).

Aydın D H, “Kadınların Adalete Erişimi”, (2015), 4, ABD, 77-107.

Aydın Ünver T ve Dursun Karaahmetoğlu Ş, 'Ana ile Çocuk Arasında Kurulan Soybağının Reddi' iç Zeynep Özlem Üskül Engin (ed), Toplumsal Cinsiyet ve Hukuk (I) (On İki Levha 2019) 299-333.

Bahtiyar M, Ticari Issletme Hukuku (21. Baskı, Beta 2020).

Bay Yllmaz Ö, ‘Topluma Değer Katan Şirketler', Ekonomist (29.12.2019) <https://www.ekonomist.com.tr/dosya/ topluma-deger-katan-sirketler.html> Erişim Tarihi 13.04.2021.

Birinci Uzun T, Aile Soyadı Çıkmazı - Anayasa Mahkemesi’nin Çocuğun Soyadının Velayeti Kendisine Bırakılan Annesi Tarafından Değiştirilmesi Hakkındaki 25 Haziran 2015 Tarihli ve 2013/3434 Başvuru Sayılı Kararının İncelenmesi' (2016) (4) Ankara Barosu Dergisi 97-137.

Bozkurt Yaşar S, Anonim Şirketlerde İşadamı Kararı İlkesinin (Business Judgment Rule) Uygulanması (Beta 2015).

Bunch C, 'Transforming Human Rights from a Feminist Perspective' iç Julie Peters Women’s Rigths, Human Rights: International Feminist Perspectives (Routledge 1995).

Centel N, "Yeni Türk Ceza Yasası Ve Kadın”, 1-16.

Centel N, Zafer H ve Çakmut Ö, Karşılaştırmalı ve Tablolu Türk Ceza Kanunu ve İlgili Mevzuat, (18.Bası, Beta 2020).

Centel N, Zafer H ve Çakmut Ö, Türk Ceza Hukukuna Giriş, (11.Bası, Beta 2020).

Centel N, Zafer H ve Çakmut Ö, Türk Ceza Kanunu, Ceza Muhakemeleri Usulü Kanun ve Yeni Türk Ceza Kanunu, (4. Bası, Beta 2004).

Charlesworth H, 'Human Rights as Men's Rights' iç Julie Peters and Andrea Wolper (eds) Women’s Rigths, Human Rights: International Feminist Perspectives (Routledge 1995).

Charlesworth H, Chinkin C and Wright S, 'Feminist Approaches to International Law' (1991) 85(4) The American Journal of International Law 613.

Çağlar-Gürgey F İ, “Feminist Hukuk Kuramı’ Nedir?’ (2014) 1(5) Hukuk Kuramı 28, 29-30.

Çağlar-Gürgey F İ ve Yücel-Dericiler Ö, 'Uluslararası İnsan Hakları Hukukunda Özen Yükümlülüğünün Dönüşümünün Bir Örneği Olarak CEDAW Komitesi’nin 35 Sayılı Tavsiye Kararı’ (2019) 1 Ankara Barosu Dergisi 231-266.

Çakırca S İ, 'Turkish Civil Code and CEDAW: Never Shall the Twain Meet?' (2015) 45(62) Annales de la Faculté de Droit d'Istanbul 145-192.

Çakmut Ö Y, “Cinsel Suçlarda Hukuksal Boyut”, (2018), 4(1), Türkiye Klinikleri Adli Tip - Özel Konular, 65-72.

Çakmut Ö Y, "Yargı Kararları Işığında Genital Muayene Suçu (TCK m.287)”, iç Yener Ünver ve İ.Hamit Hancı (edr), V. Uluslararası Sağlı Hukuku Kongresi, Özyeğin Üniversitesi Hukuk Fakültesi, Adli Bilimciler Derneği, Balıkesir Barosu, (Seçkin 2020), 125-138.

Çakmut Ö Y ve Akyıldız A, "Sporda Ayrımcılık ve Türk Ceza Hukuku” (2021), III (2), İstanbul Spor Hukuku Dergisi, 3-53.

Çelebi Ö, 'Toplumsal Cinsiyet Eşitliği Bağlamında Kadının Soyadı ve Soyadının Çocuğa Aktarımı' (2019) (2) Galatasaray Üniversitesi Hukuk Fakültesi Dergisi 537-614. 
Demir E, Sermaye Piyasası Kurulu’nun Anonim Şirketlerdeki Yönetim Kuruluna İlişkin Kurumsal Yönetim İlkeleri (Oniki Levha 2013).

Develioğlu M, 'Rupture d'égalité entre hommes et femmes autour de la question du nom de famille en Turquie' (2013) 65(4) Revue Internationale de Droit Comparé 859-878.

Dönmezer S, Umumî Âdap ve Aile Nizamı Aleyhine Cürümler, (İstanbul Üniversitesi Yayınları 1945).

Dumanlı D, 'Reklamlarda Toplumsal Cinsiyet Kavramı ve Kadın İmgesinin Kullanımı; Bir İçerik Analizi’ (2011) 1(2) Yalova Sosyal Bilimler Dergisi 132-149.

Ekşi N, 'Medeni Kanunun Kadının Soyadına İlişkin Hükmünün AİHS, Anayasa, Cedaw ve Möhuk Kapsamında Değerlendirilmesi' (2012) Yeditepe Üniversitesi Hukuk Fakültesi Dergisi Özel Sayıs1, 2011/II - 2012/I, Prof.Dr. Erhan ADAL’a Armağan 311-331.

“En Yüksek Kadın İstihdam Oranı Yüzde 55 İle Sigorta Sektöründe” Sigortix (2014)

Erdem J G, "Yargı Kararlarında Kanun Önünde Eşitlik İlkesi Ve Kadın Erkek Eşitliği”, (2017), 4 (8), Akademik Hassasiyetler, 19-44.

Ergene D, 'İnsan HaklarıHukukundaki Gelişmeler Işı̆̆ında Türk Hukukunda Kadının ve Çocuğun Soyadı Meselesi ve Medeni Kanunda Değişiklik Önerisi’ (2011) 31(2) Milletlerarası Hukuk ve Milletlerarası Özel Hukuk Bülteni, 123-176.

Ertürk Y, Sınır Tanımayan Şiddet: Paradigma, Politika ve Pratikteki Yönleriyle Kadına Şiddet Olgusu, (Metis 2015).

Gerçek L Ç, "Yargıtay Kararlarıly Cinsel Taciz Suçu”, (2011), 60 (1), AÜHFD, 47-82.

"Goal5: Achievegenderequalityandempowerallwomenandgirls",<https://www.un.org/sustainabledevelopment/ gender-equality/> Erişim Tarihi 13 Eylül 2021.

Göktürk K, 'Amerikan, Alman, İsviçre ve Türk Hukukunda İşadamı Kararı İlkesi' (2011) 2(2) İnönü Üniversitesi Hukuk Fakültesi Dergisi 207-246.

Gülseven A S, 'Türk Aile Hukukunda Toplumsal Cinsiyet Rolleri' (2017) (132) Türkiye Barolar Birliği Dergisi 183-230.

Helvacı S, 'Avrupa İnsan Hakları Mahkemesinin ve Anayasa Mahkemesinin Kararları Işı̆̆ında Evli Kadının Soyadi' (2015) 35(1) MHB 157-169.

Işıntan P, ‘Anayasa Mahkemesinin 8.12.2011 Tarihli Kararı Işığında Türk Hukukunda Velayet Hakkı Kendisine Verilmiş Kadının Çocuğun Soyadını Seçme Hakkı Mevcut Mudur?' (2012) (1) Galatasaray Üniversitesi Hukuk Fakültesi Dergisi 265-279.

Kamuajans, ‘Girişimci Kadınlara 2021 Yllı Destek Veren Kamu Kurumları ve Sivil Toplum Örgütleri’ (Kamuajans, 16.06.2021) <https://www.kamuajans.com/> Erişim Tarihi: 26.09.2021.

Karan U, "Türk Hukukunda Ayrımcılı Yasağı ve Türk Ceza Kanunu’nun 122.Maddesinin Uygulanabilirliği" (2007), 20 (73), Türkiye Barolar Birliği Dergisi, 146-173.

Kaufman N H ve Lindquist S A, 'Critiquing Gender-Neutral Treaty Language: The Convention on the Elimination of All Forms of Discrimination against Women' in Julia Peters ve Andrea Wolper (eds), Women's Rights, Human Rights: International Feminist Perspective (Routledge 1995), 114-125.

Kaya F, 'Reklam ve Pazarlama Stratejileri: Bir Reklamda Olması Gerekenler' (2018) 3(5) Mecmua Uluslararası Sosyal Bilimler Dergisi 99-111.

Keskin S, 'Kadın ve Erkek Girişimciler Arasındaki Farklılıklar' (2017) 1(1) Mersin Üniversitesi Sosyal Bilimler Enstitüsü e-Dergi 64-76.

Kılınç Savrul B ve Akyüz D, 'Türkiye Ekonomisinde Kadın Girişimcilerin Mevcut Durumu ve Geliştirilmesine Yönelik Çözüm Önerileri’ (2016) 11(1) ÇÖMÜ Girişimcilik ve Kalkınma Dergisi 165-185.

Kılıçoğlu A, 'Medeni Kanun Açısından Kadın-Erkek Eşitliğii' (1991) (1) Ankara Barosu Dergisi 9-17. 
Mikkola M., 'Feminist Perspective on Sex and Gender', (Stanford Encyclopedia of Philosophy Fall 2019 edition), Edward N. Zalta (ed.), <https://plato.stanford.edu/archives/fall2019/entries/feminism-gender/> Erişim Tarihi 13 Ağustos 2021.

Moroğlu N, 'Kadının Kimlik Sorunu: Kadının Soyadı' (2012) Türkiye Barolar Birliği Dergisi 245-268.

Mossman M J, "Shoulder To Shoulder": Gender and Access To Justice”, 350-363.

Nomer H, 'Avrupa Birliği’ne Üye Devletlerde ve Türkiye'de Evlenen Kadının ve Ortak Çocuğun Soyadı' (2002) (22) Milletlerarası Hukuk ve Milletlerarası Özel Hukuk Bülteni 421-450.

Nowak M, International Human Rights Regime (Martinus Nijhoff Publishers 2003).

Oakley A, Sex, Gender and Society (Gower Publishing 1985).

Oktay Özdemir S, 'Soyadı ve ile İlgili İsviçre Medeni Kanunu’nda 2013 Yılında Yürürlüğe Giren Değişiklikler ile Türk Hukukundaki Durumun Karşılaştırılması' (2016) 22(3) Marmara Üniversitesi Hukuk Fakültesi Hukuk Araştırmaları Dergisi 2017-2032.

Önder A, Türk Ceza Hukuku, Özel Hükümler, (4.Bası Filiz Kitabevi 1994).

Özen B, 'Soyadının Soybağı Yoluyla Kazanılması ve Bu Yolla Kazanılan Soyadında Değişiklik Yapılması' (2010) 16(3-4) Marmara Üniversitesi Hukuk Fakültesi Hukuk Araştırmaları Dergisi 171-194.

Özkaya E, Açıklamalı - İçtihatlı İnançlı İslem ve Muvazaa Davaları (7. Baskı, Seçkin 2017).

Pulaşlı H, 'Türk Ticaret Kanunu Tasarısı’na Göre Anonim Şirket Yönetim Kurulu Üyelerinin Özen Yükümlülügü ve Müteselsil Sorumluluğu’ (2009) 25(1) BATIDER 27-63.

Reyhani Yüksel S, 'Türk Medenî Kanunu Bakımından Kadın-Erkek Eşitliği' (2014) 18(2) Gazi Üniversitesi Hukuk Fakültesi Dergisi 175-200.

Romany C, 'Women as Aliens: A Feminist Critique of the Public/Private Distinction in International Human Rights Law' (1993) 6 Harvard Human Rights Journal.

Sabancı Üniversitesi Kurumsal Yönetim Forumu, 'Türkiyede Yönetim Kurulunda Kadınlar' (Yönetim Kurulunda Kadın Derneği, 2020) <https://www.yonetimkurulundakadin.org/assets/node_modules/source/pdf/ sabanci-2020-8th_yillik_rapor.pdf> Erişim Tarihi: 25.04.2021.

Scales A, Hukuki Feminizm: Aktivizm, Savunma ve Hukuk Kuramı (Dost 2019).

Serozan R, Çocuk Hukuku (2. Baskı, Vedat 2005).

Sert Sütçü S, Miras Brrakanın Muvazaalı Hukuki İşlemleri ve Sonuçları (1. Bask1, Seçkin 2018).

Songur D, 'Toplumsal Cinsiyet Eşitliği Perspektifinden Ticaret Hukuku ve Uygulamasına Genel Bakış’ iç Gülriz Uygur ve Nadire Özdemir (edr) Hukuk ve Toplumsal Cinsiyet Çalışmaları (Seçkin 2018) 413-432.

Sullivan D, 'The Public/Private Distinction in International Human Rights Law' in Julia Peters ve Andrea Wolper (eds), Women's Rights, Human Rights: International Feminist Perspective (Routledge 1995).

Şıpka Ş, 'Taşıyıcı Annelik ve Getirdiği Hukuki Sorunlar' <https://www.turkhukuksitesi.com/makale_537.htm> Erişim Tarihi 24.12.2018.

Şimşek A, 'Bir İnsan Hakları İhlali ve Ayırımcılık Biçimi Olarak Toplumsal Cinsiyet Rolleri ve Kalıpyargılar: CEDAW Çerçevesinde Bir İnceleme’ (2020) 11(2) İnönü Üniversitesi Hukuk Fakültesi Dergisi 496-513.

Toluay M, İnsan Hakları Hukukunda Cinsiyet Temelinde Ayrımcılık Yasağı, (1.Bası Onikilevha 2021).

Türkiye Kadın Girişimciler Derneği (KAGIDER), 'Türkiye Kadın Girişimcilik Endeksi - 2019 Araştırma Raporu' (Cinsiyet Eşitliği İzleme Merkezi, 2019) <https://dspace.ceid.org.tr/xmlui/handle/1/427> Erişim Tarihi: 20.04.2021.

UNESCO moving forward the 2030 Agenda for Sustainable Development, <https://en.unesco.org/creativity/ sites/creativity/files/247785en.pdf> Erişim Tarihi 13 Eylül 2021 
Uygur G, “Toplumsal Cinsiyet ve Adalet: Hukuk Adaletsizdir”, (2015), 4, Ankara Barosu Dergisi, 121-132.

Uygur G ve Özdemir N, 'Giriş’ iç Gülriz Uygur, Nadire Özdemir (edr), Hukuk ve Toplumsal Cinsiyet Çalışmaları (Seçkin 2018) 7.

Uygur G ve Özdemir N, 'Hukuk eğitiminde Toplumsal Cinsiyet Eşitliğine İlişkin Problemler ve Çözüm Önerileri: Etik Temelde Bir Arayış-Dönüşüm İlkesi I’ iç Gülriz Uygur, Nadire Özdemir (edr), Hukuk ve Toplumsal Cinsiyet Çalışmaları (Seçkin 2018).

Vujadinovic D., '“Gender Mainstreaming in Law and Legal Education', (2015) 3 Belgrade Law Review, 63,<https://www.researchgate.net/publication/314484835_Gender_mainstreaming_in_law_and_legal_ education > Erişim Tarihi 1 Ağustos 2021.

Yelkikalan N, 'Başarılı Girişimcilikte Cinsiyetin Rolü: Kadın Girişimciler' (2006) 1(1) ÇÖMÜ Girişimcilik ve Kalkınma Dergisi 45-54.

Yıldız Ş, Anonim Ortaklıkta Pay Sahipleri Açısından Eşit İşlem İlkesi (Seçkin 2004).

Yongalık A, 'Pozitif Ayrımcılığın Aracı Olarak Hukuk: Şirket Yönetim ve Denetim Kurullarında Kadın Kotası Uygulaması', iç Fatma Güven Lisaniler ve Süheyla Üçışık Erbilen (edr) Toplumsal Cinsiyet Eşitliği ve Hukuk: 4. Uluslararası Kadın/Toplumsal Cinsiyet Çalışmaları Konferansı, Bildiri Özetleri Kitabı (2012) 5.

Yücel-Dericiler Ö, Sosyal Haklar ve İnsan Hakları Hukukunda Devletin Yükümlülükleri: Refah Devletinin Krizi Ekseninde Bir İnceleme (On İki Levha 2014).

\section{INNTERNET SAYFALARI}

<http://www.sigortatahkim.org/files/karardrgs46.pdf> Erişim Tarihi 12.07.2021.

$<$ https://normkararlarbilgibankasi.anayasa.gov.tr/ND/1991/40?KararNo=1991\%2F40> Erişim Tarihi 04.05.2021.

<https://tsb.org.tr/media/attachments/Deniz_Aracları_Zorunlu_Mali_Sorumluluk_Sigortası_Genel_Sartlar1. pdf> Erişim Tarihi 10.07.2021.

<https://tsb.org.tr/media/attachments/Emtea_Nakliyat_Sigortası_Genel_Sartları.pdf> Erişim Tarihi: 10.07.2021.

<https://tsb.org.tr/media/attachments/Tekne_Policesi_Genel_Sartları.pdf > Erişim Tarihi 10.07.2021.

$<$ https://www.barobirlik.org.tr/Haberler/2019-avukat-sayilari-31122.019.81078> Erişim Tarihi 04.05.2021.

$<$ https://www.echr.coe.int/Documents/Convention_TUR.pdf > Erişim Tarihi 04.05.2021.

$<$ https://www.hsk.gov.tr/Eklentiler/Dosyalar/39c8a8cb-7600-4159-933b-48881447fod4.pdf> Erişim Tarihi 04.05.2021.

<https://www.legislation.gov.uk/ukpga/Edw7/6/41/contents > Erişim Tarihi 10.07.2021.

$<$ https://www.mevzuat.gov.tr/mevzuat> Erişim Tarihi 04.05.2021.

$<$ http://www.multeci.org.tr/wp-content/uploads/2016/12/Insan-Haklari-Beyannamesi-1.pdf> Erişim Tarihi 04.05.2021.

<https://www.oxfordlearnersdictionaries.com/definition/english/gender?q=gender> Erişim tarihi 13 Ağustos 2021. 
$<$ https://www.researchgate.net/publication/342511353_Turkiye'de_Akademide_Cinsiyet_Esitsizligi_ Raporu_2020_Gender_Inequality_Report_at_the_Academy_in_Turkey_2020 > Erişim Tarihi 04.05.2021.

$<$ https://www.sigortix.com/haberdetay-HaberID-132-Haber-en-yuksek-kadin-istihdam-orani-yuzde-55-ilesigorta-sektorunde.html> Erişim Tarihi 15.07.2021.

<https://www.tsb.org.tr/tr/istatistikler> Erişim Tarihi 23.07.2021.

$<$ https://www.willistowerswatson.com/tr-TR/About-Us/overview> Erişim Tarihi 12.07.2021.

Lexpera <https://www.lexpera.com.tr/> Erişim Tarihi 30.09.2021

Yargıtay Bilgi Bankası <https://karararama.yargitay.gov.tr/YargitayBilgiBankasiIstemciWeb/>, Erişim Tarihi 24.12.2020. 
